\title{
معالم الحضارة فى العصر الصفوى من خلال كتب الرحالة
}

\author{
مصطقى موسى محمد شرف \\ أستاذ الحضارة الفارسية المساعد

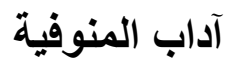

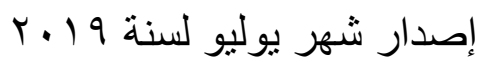

شعبة النشر و الخدمات المعلوماتية 
" إن الحضارة ؛ أى حضارة ؛ هى جزء من سلسلة دائمة التواصل ، مستمرة

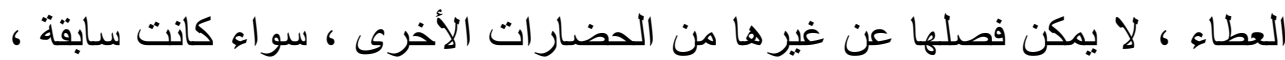

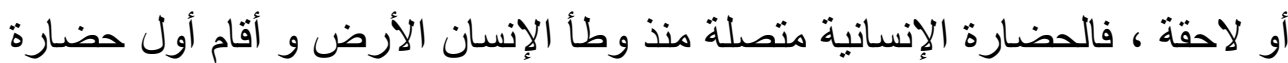

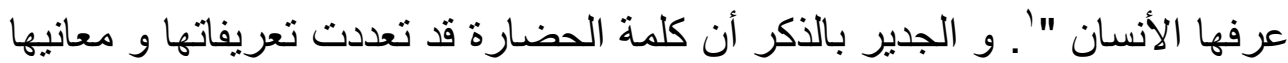

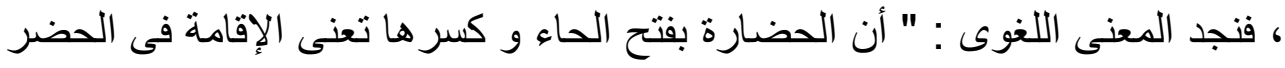

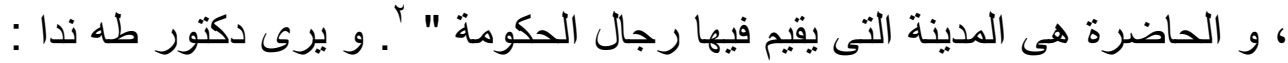

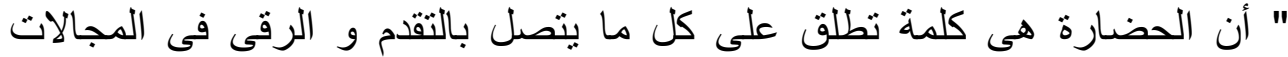

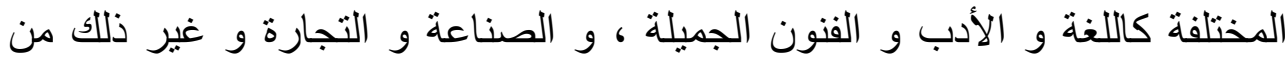

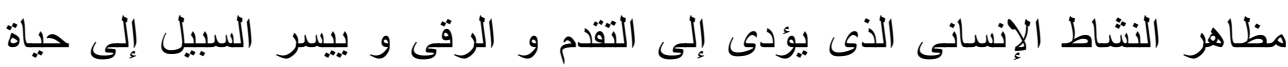

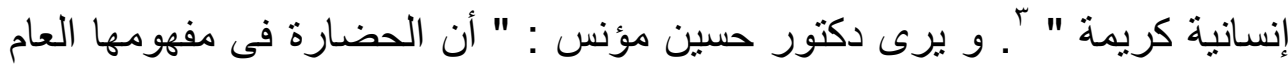

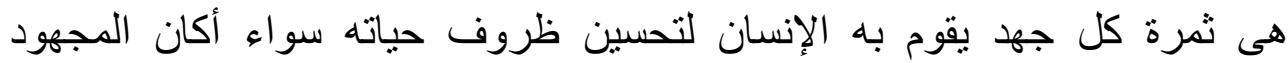
المبذول للوصول إلى تلك الثمرة مقصوداً أو غير مقصود، و سواء أكانت الثران الثمرة مادية أم معنوية " "لكول ألى

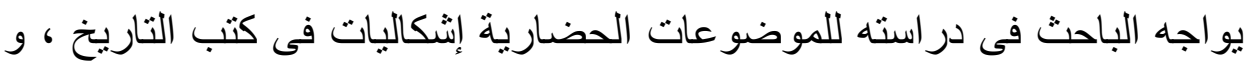

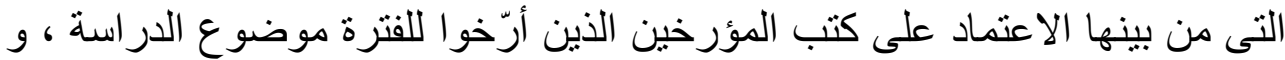

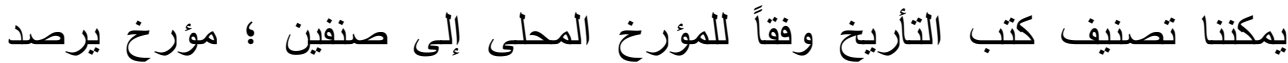

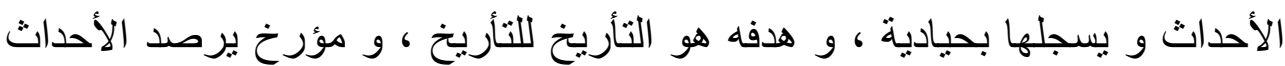

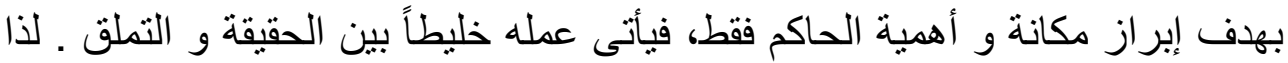

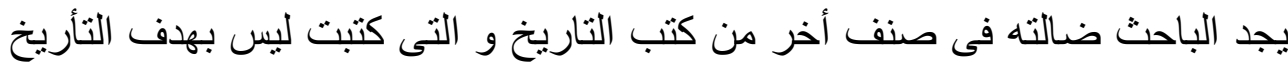

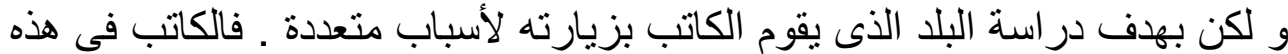

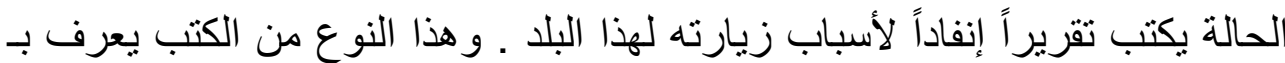

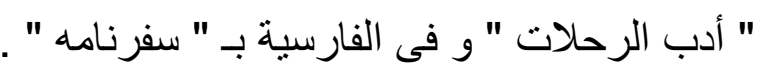

ا- الثناذلى : أحمد عبد القادر ( دكتور ) ،الحضارة الإسلامية و قطوفها الدانية فى علوم اللغة العربية و اللغات

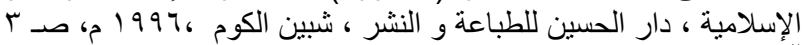

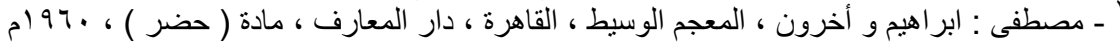

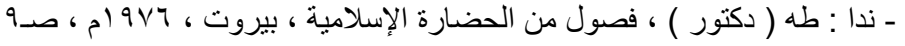

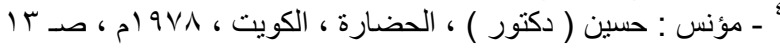




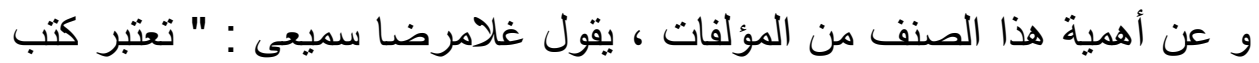

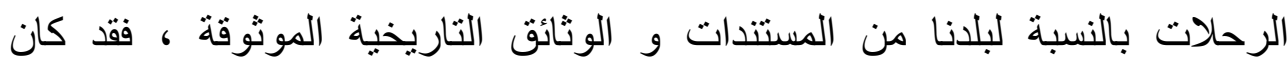

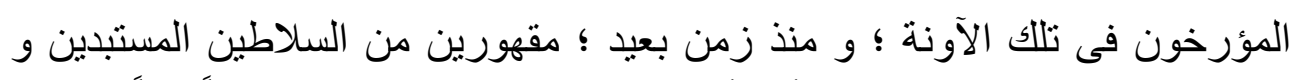

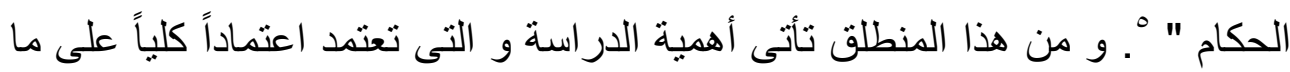

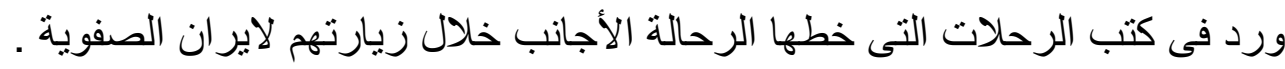

تقوم الدراسة على تحليل و وصف ما رصدئ الرداه الرحالة الأجانب من مظاهر

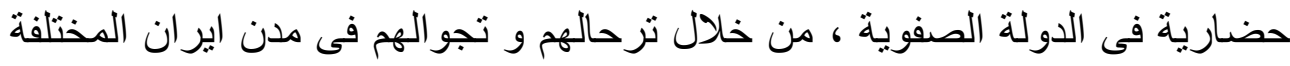

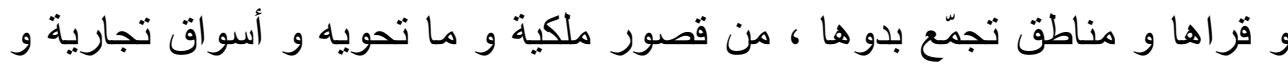

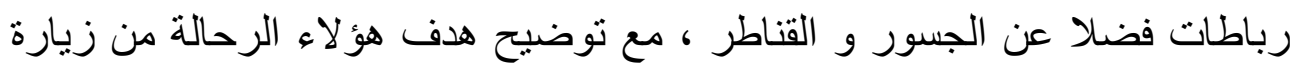
ايران ، و من أين دخلوا هذا البلد ، و من أين جاءت قور فو افلهم و بعثاتهم .

و قد انتهجت فى هذه الدراسة ، و التى جاءت تحت عنوان "جوانب من الحضارة

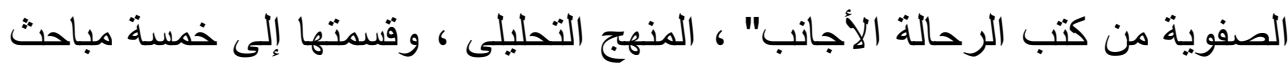

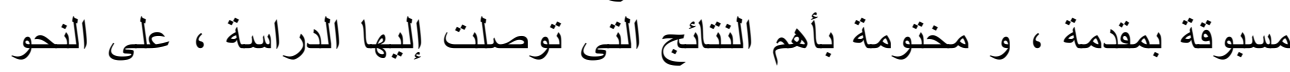
التالى :

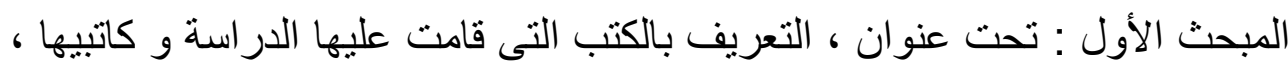

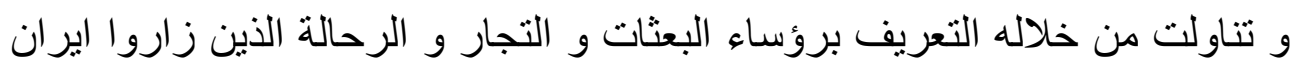

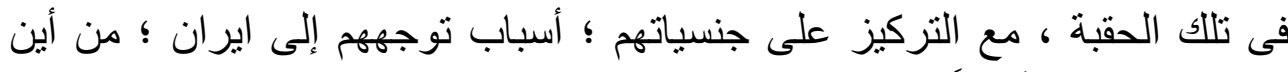

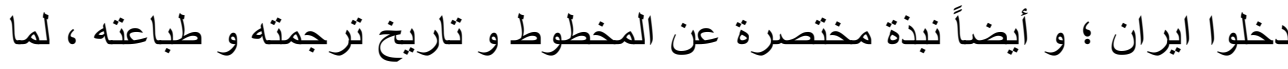

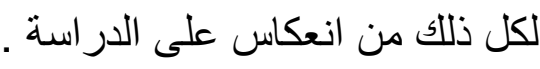

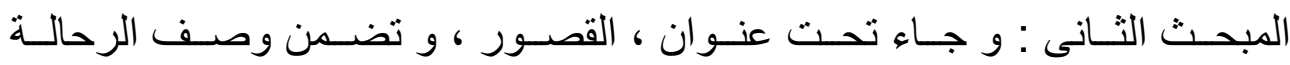

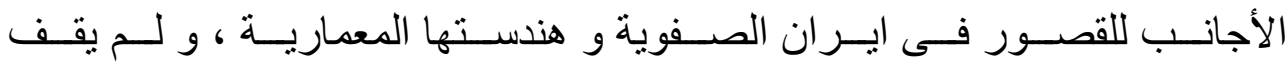

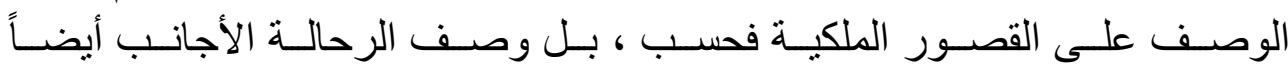

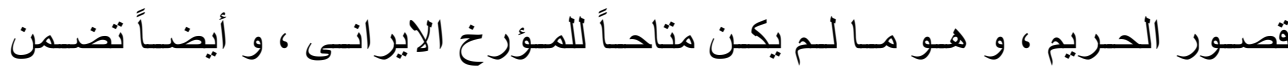

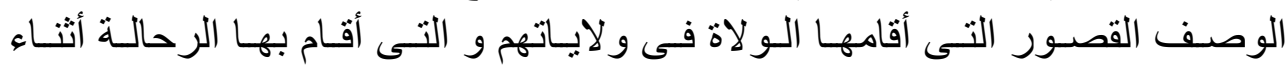

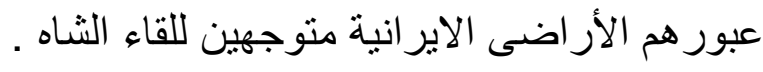




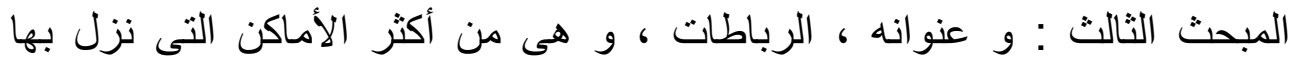

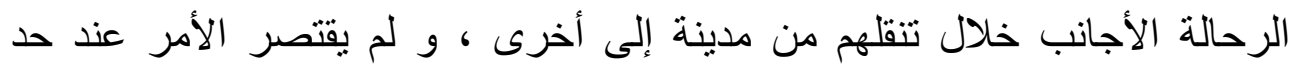

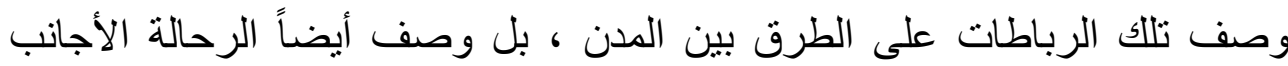

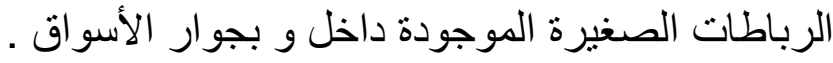

المبحث الرابع : وعنوانه ، الأسواق و المقاهى ، و هـى من الأماكن ذات الأهمية

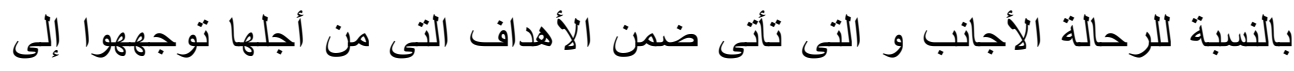

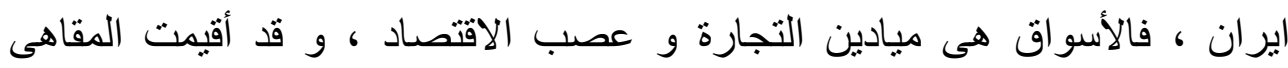

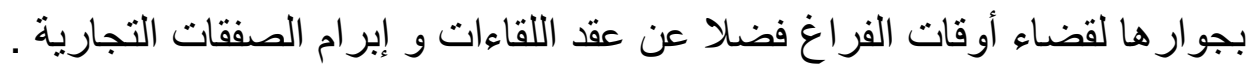

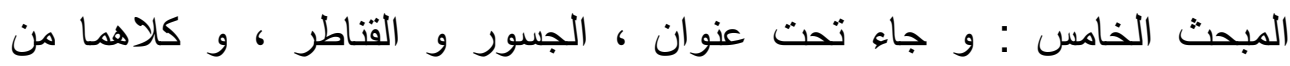

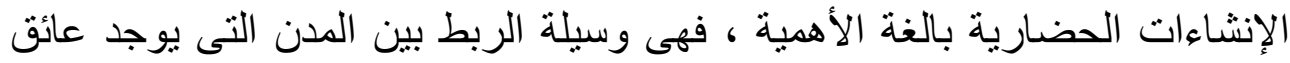

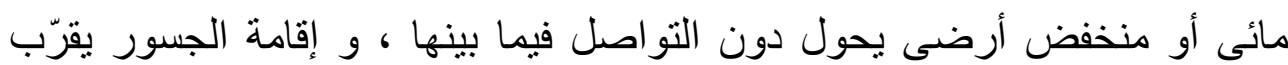

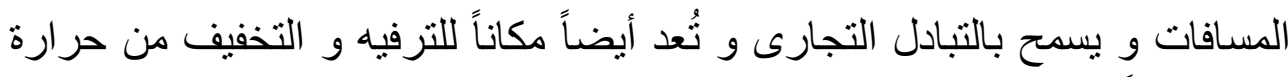

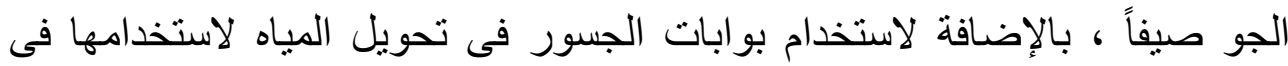

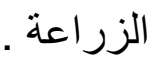

هذا ، و ما كان من توفيق فمن الله ، و ما كان من تقصير فمن نفسى ، و على الله

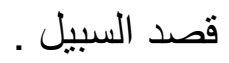




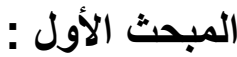

\section{التعريف بالكتب التى قامت عليها الاراسة و كاتبيها :}

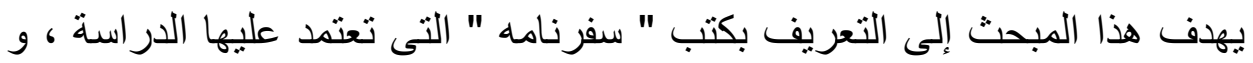

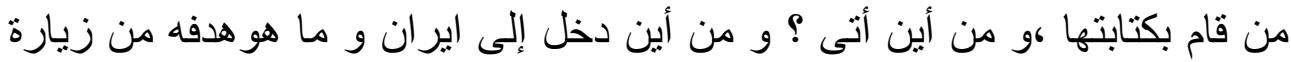

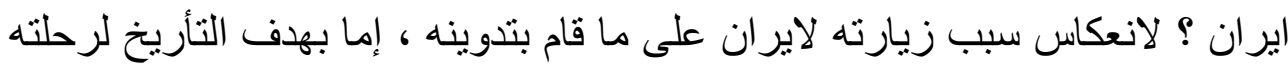

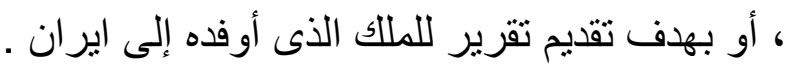

قبل الخوض فى التعريف بالرحالة الأجانب و كتبهم التى كتبوها حول زيارتهم

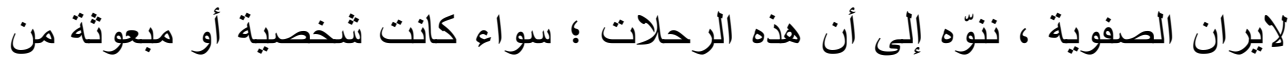

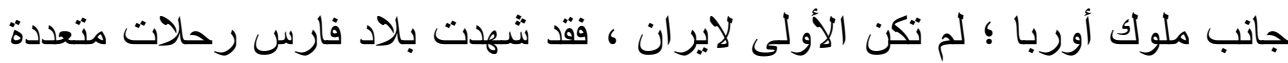

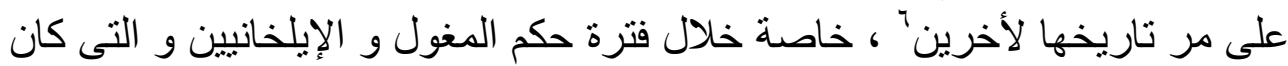

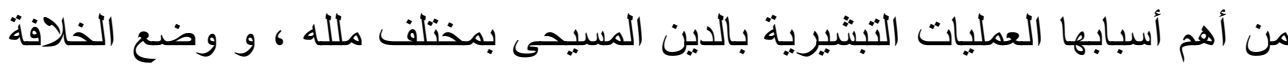

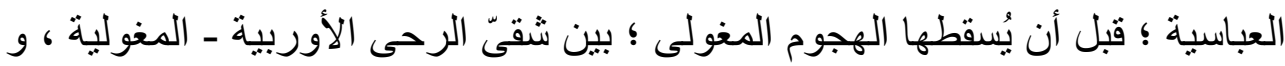

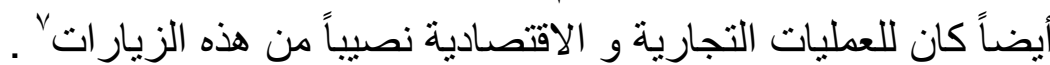

أما فى الدولة الصفوية ، و بعد توحيد مدن ايران تحت الحكم الصفوى ، و و وائوان

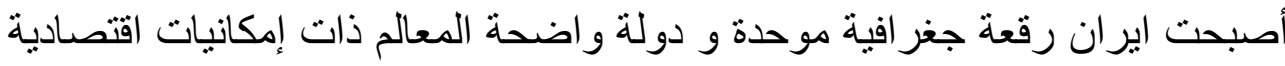

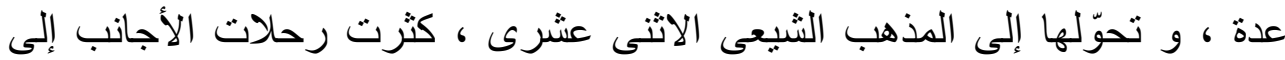

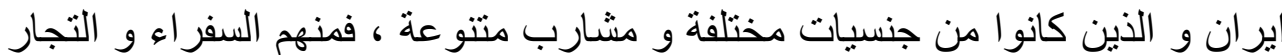

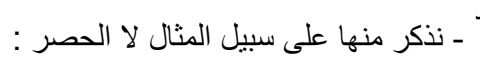
ابو الدلف الينبعى : سعر بن المهلهل ، ترجمهاء سيد ابو الفضل الطباطبائى ، با تعليقات و تحقيقات : و لاديمير

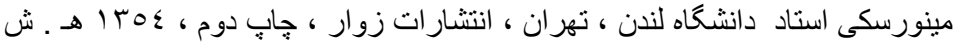

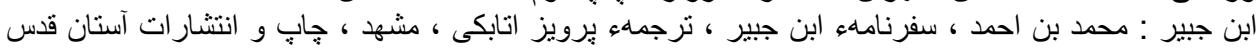

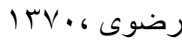

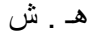
ابن بطوطة : شمس الدين أبو عبد الله محمد بن إبراهيم اللواتى الطنجى ، تحفة النظّار فى غرائب الأمصار و

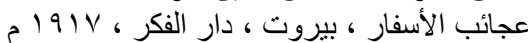

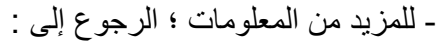

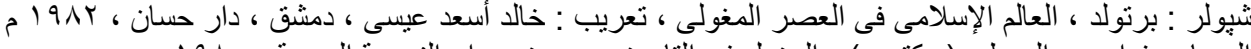

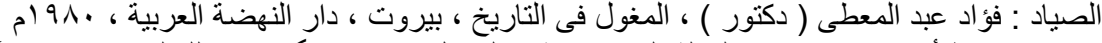

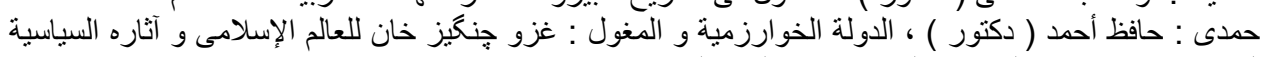

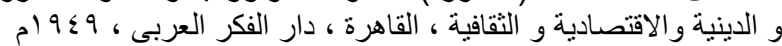
ابن الأثير : عز الإين الدين أبى الحسن على بن محمد بن عبد الكريم الجزرى ، المَ ، الكامل فى التاريخ ، بيروت ، دار 
و منهم الساسة و العسكريين و المبعوثين الثخصبين للملوك ـ هؤل لاء أقاموا في ايران

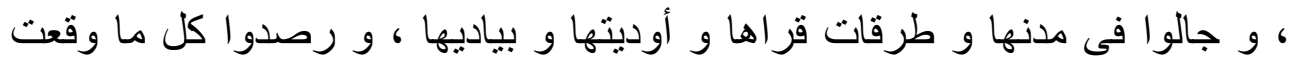

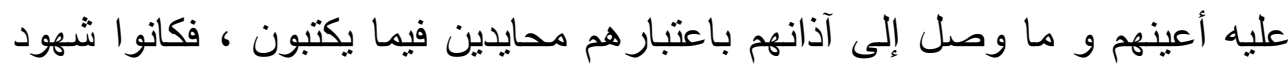

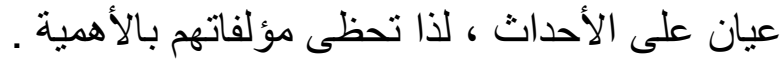

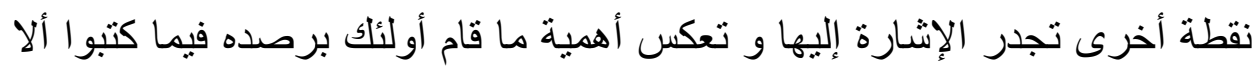

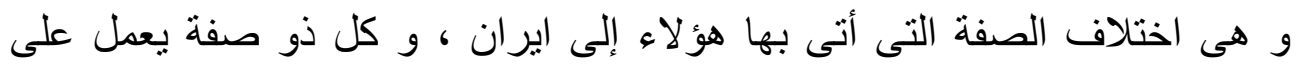

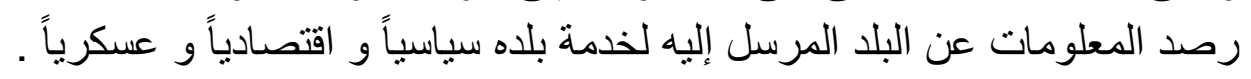

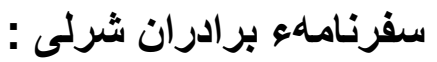

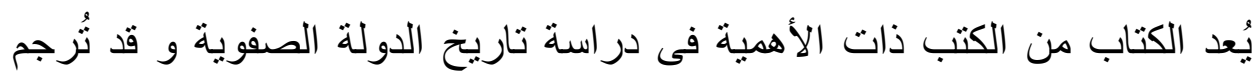

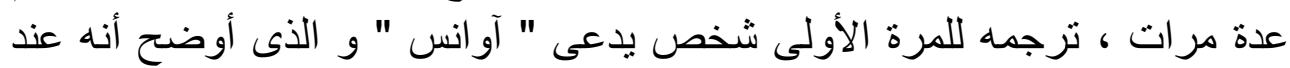

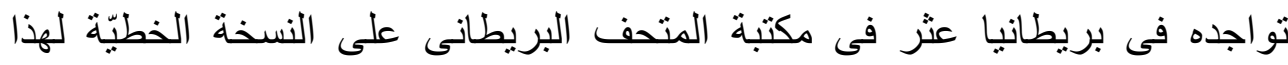

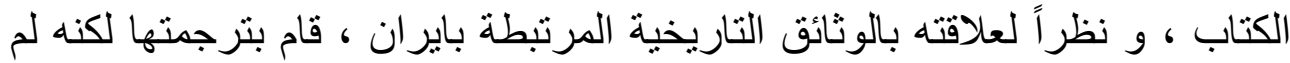

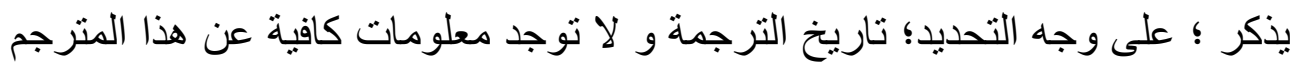

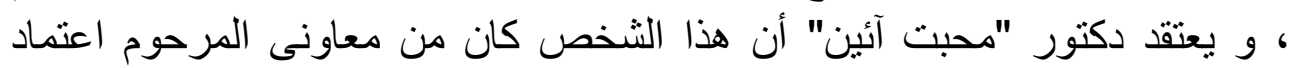

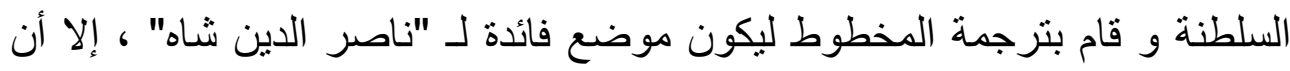

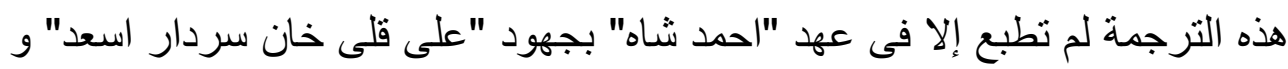

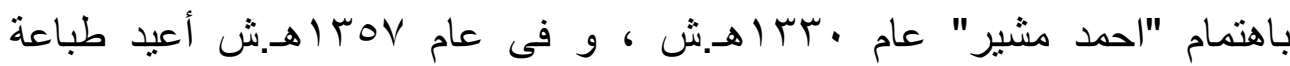

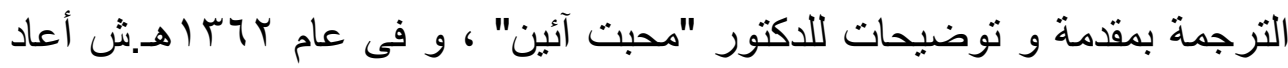

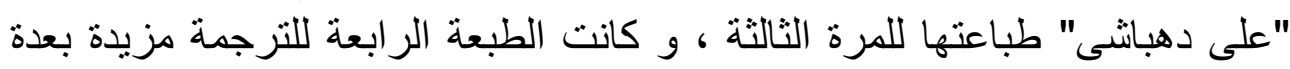

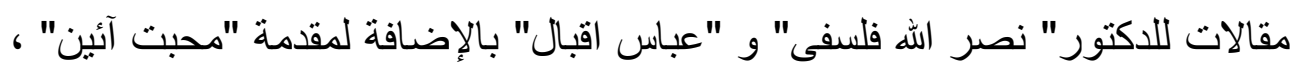

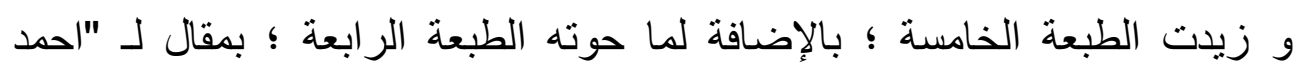

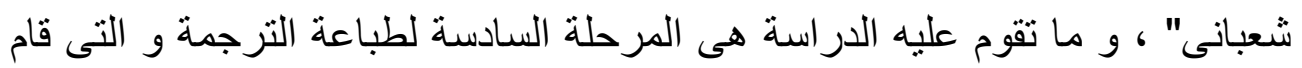

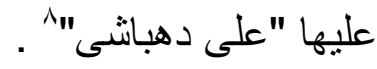

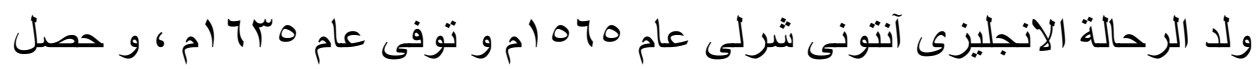

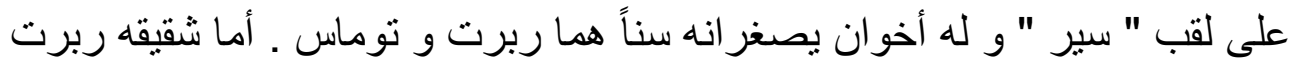

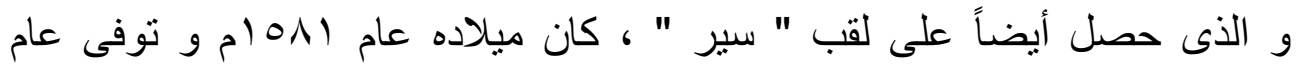

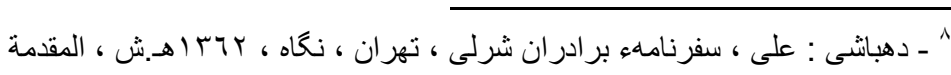




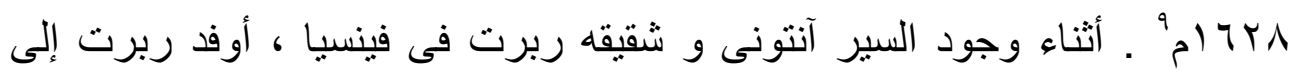

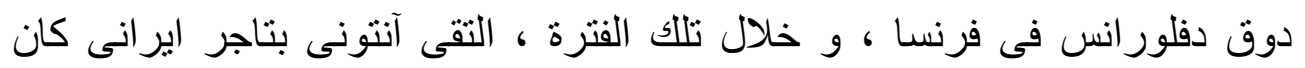

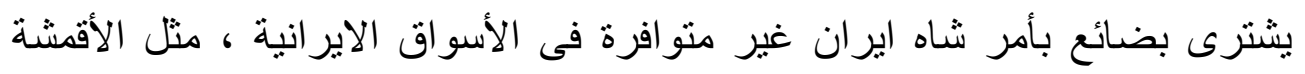

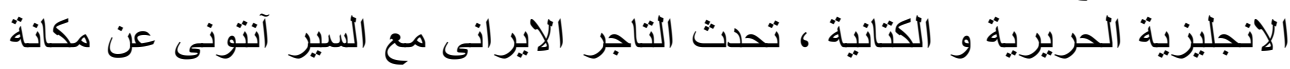

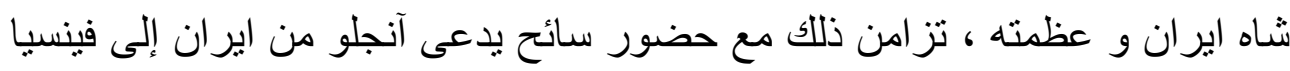

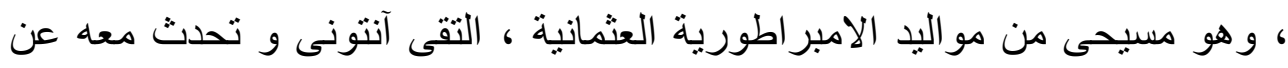

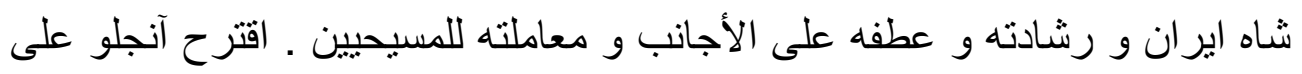

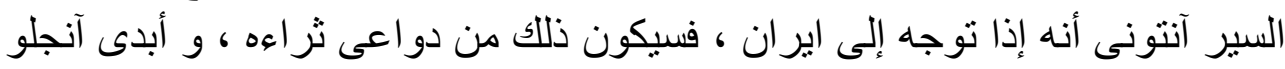

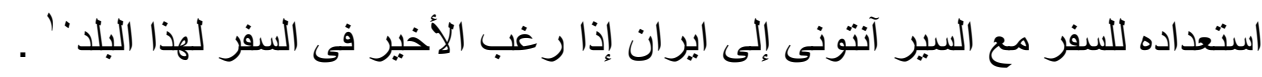

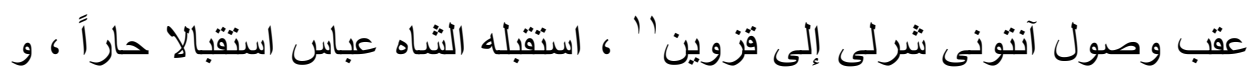

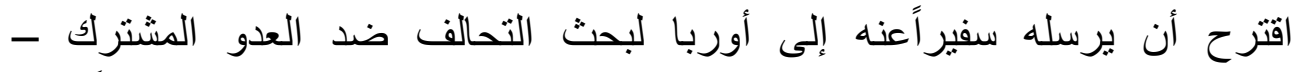

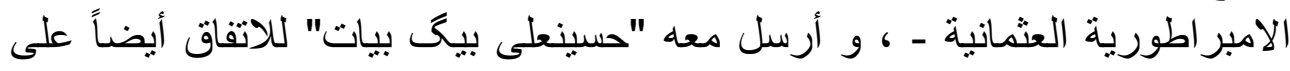

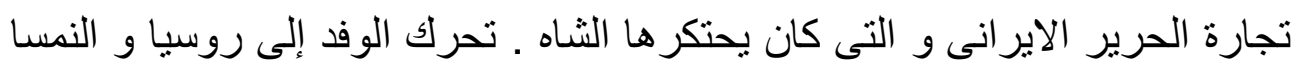

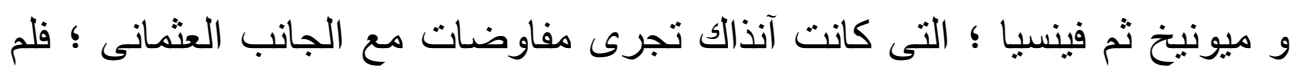

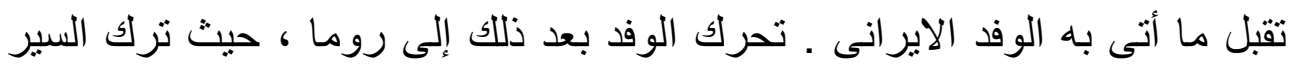

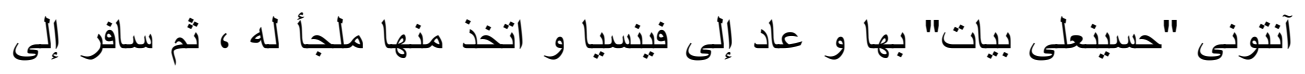

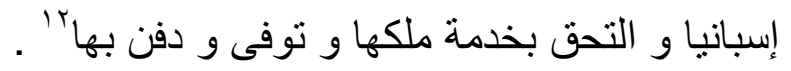

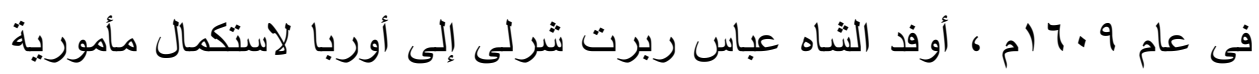

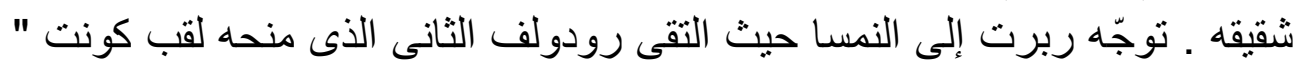

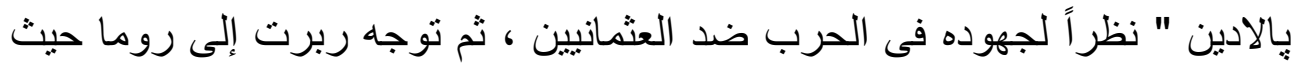

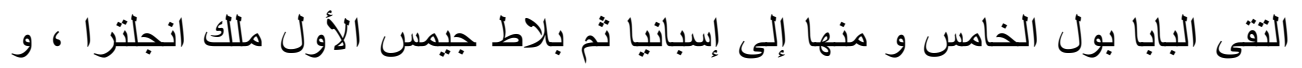

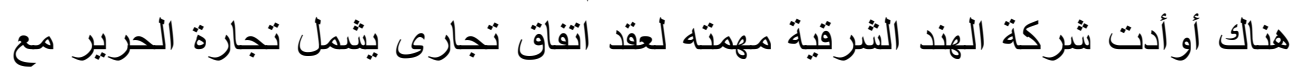

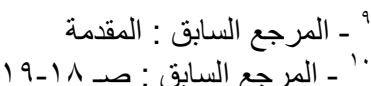

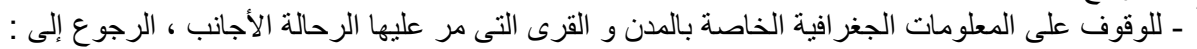

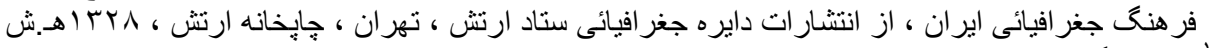

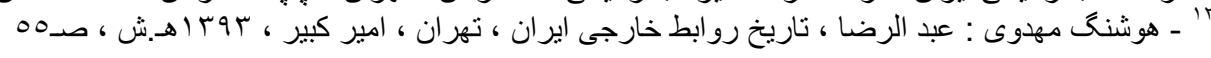


اير ان ، حفاظاً على مصالحها في الهند و تجارتها مع الامبر اطورية العثمانية ، إلا أن

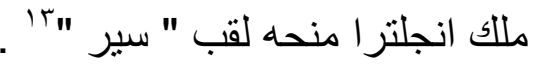

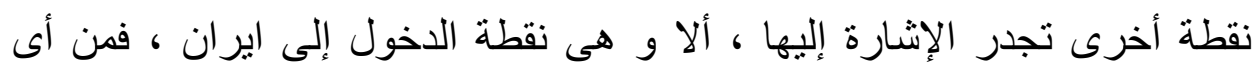

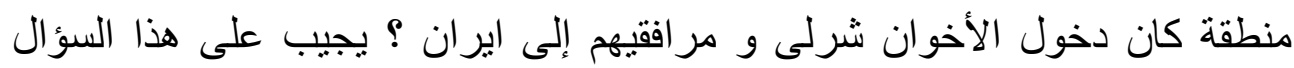

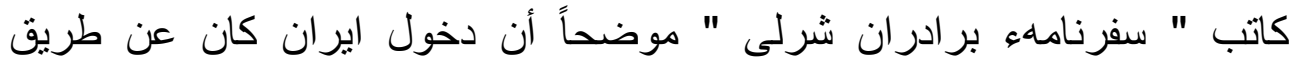

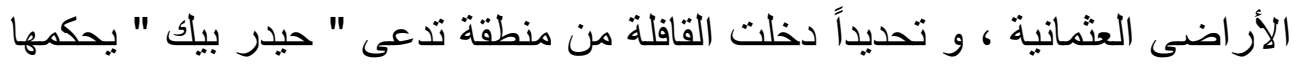

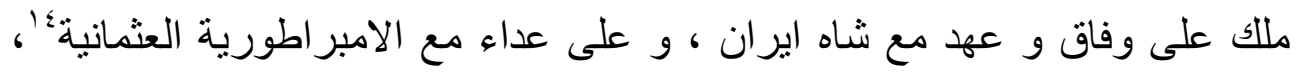

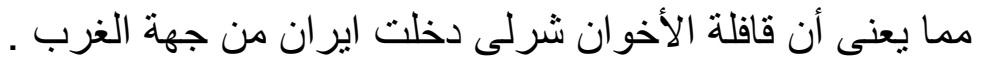

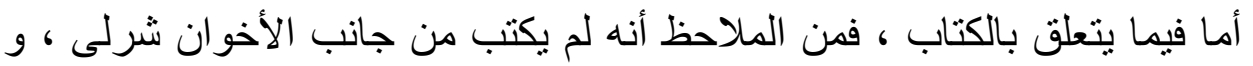

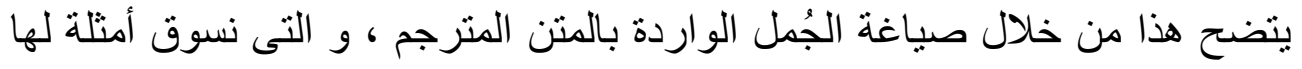

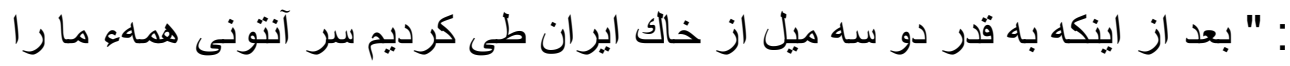

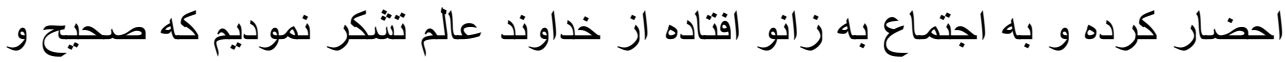

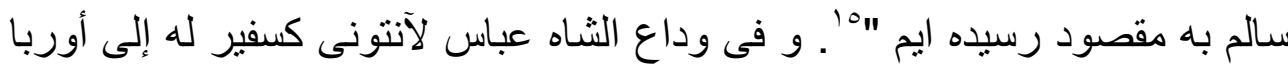

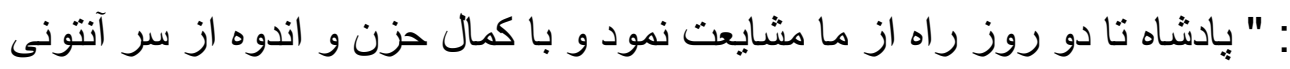

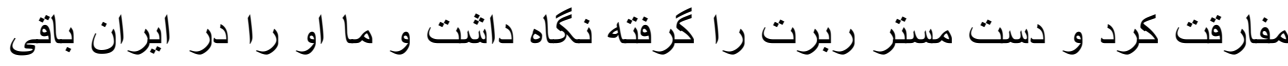

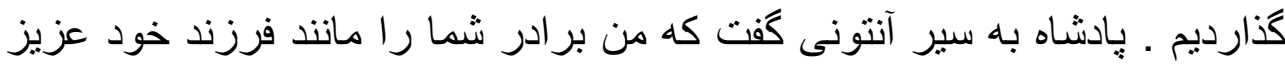

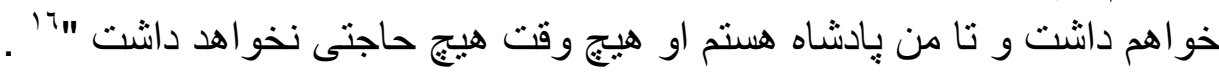

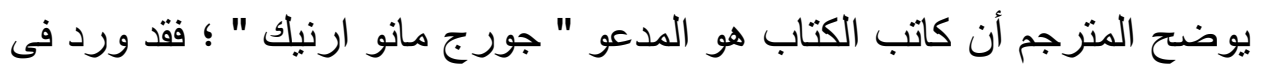

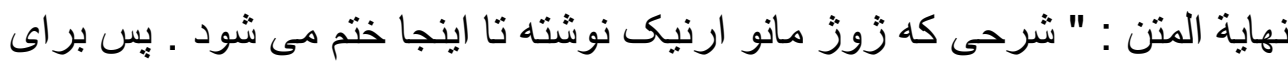

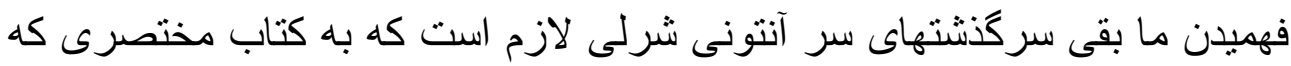

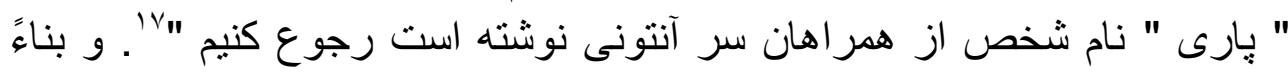

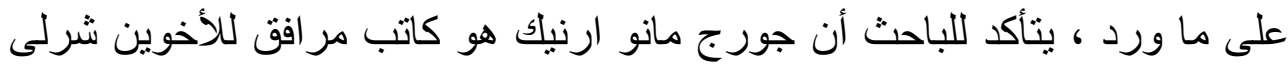

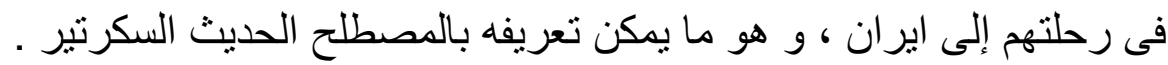

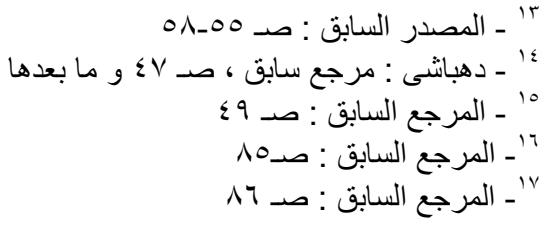




\section{سفرنامهو دن كارسيا دسيلوا فيكوئروا :}

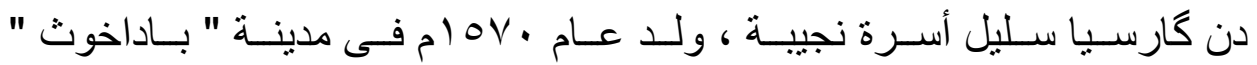

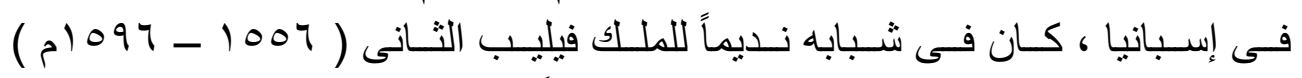

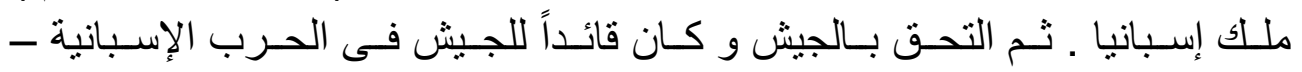

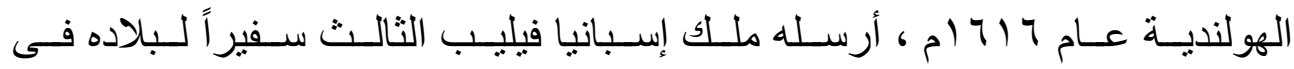

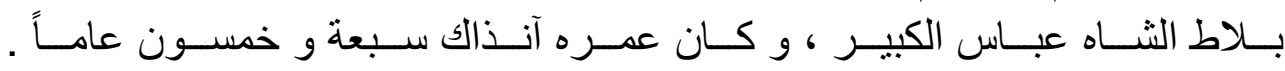

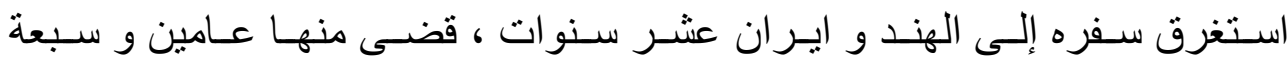

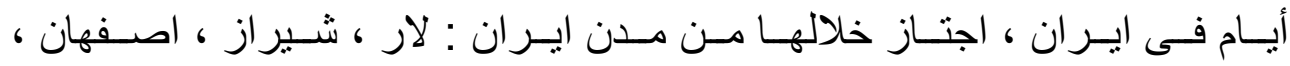

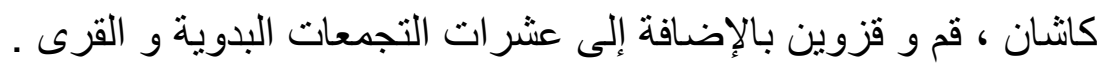

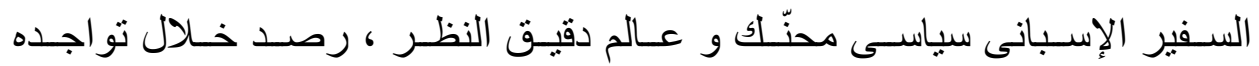

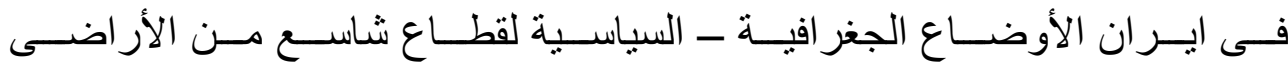

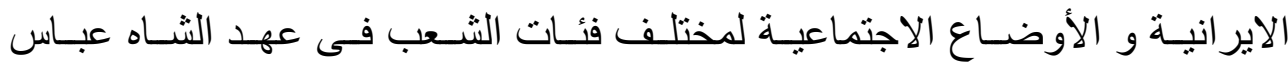

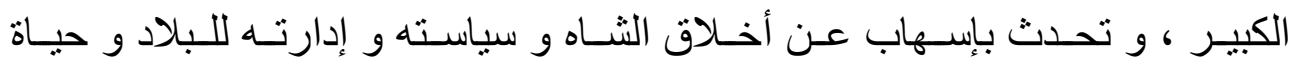

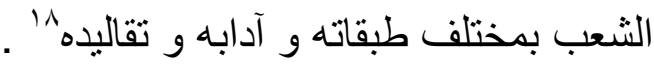

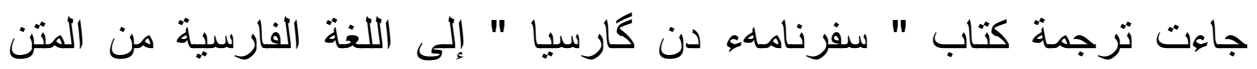

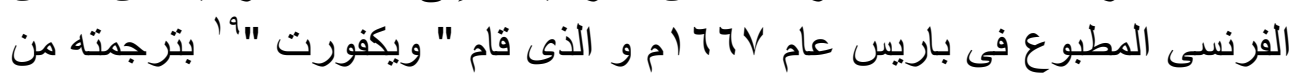

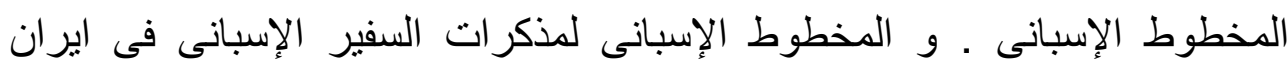

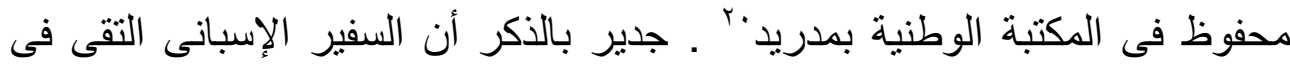

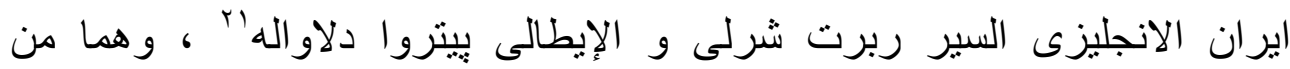

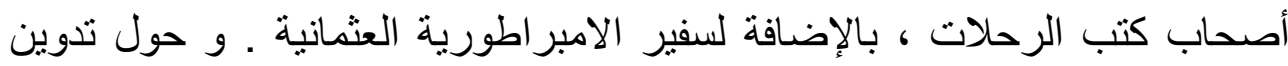

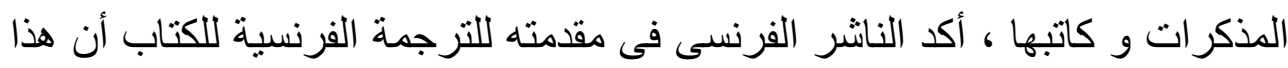

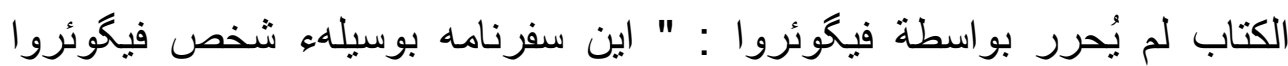

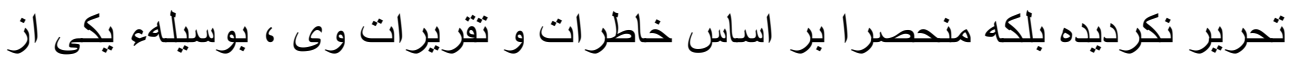

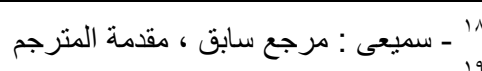
Abraham de Wicquefort - '19

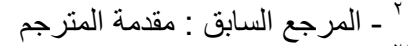

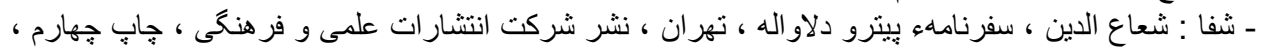




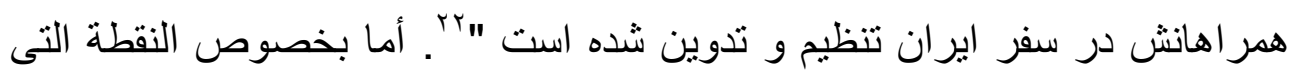

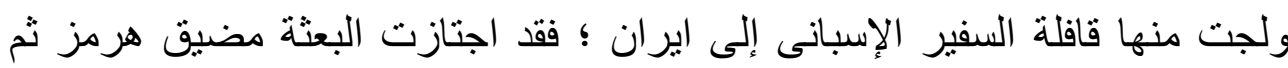

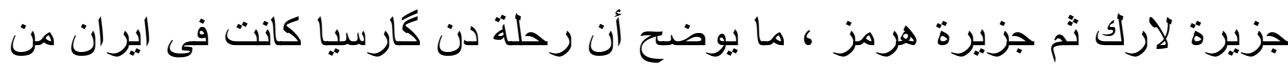

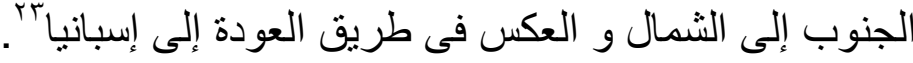

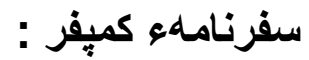

طُبع المنن الأصلى عام • ، 9 ام ، و و جاءت الترجمة الفارسية للمرة الأولى عام

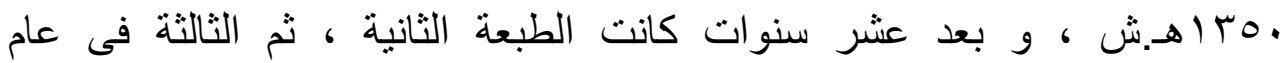

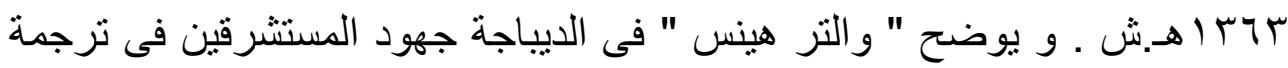

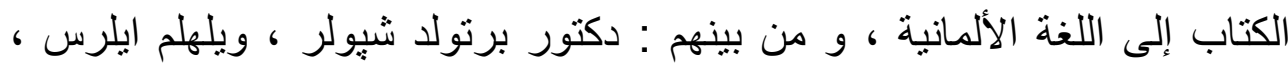

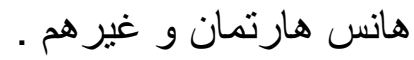

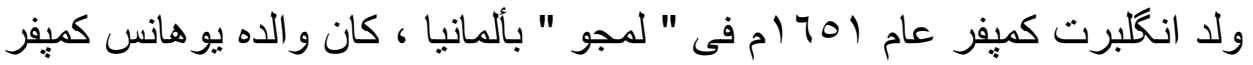

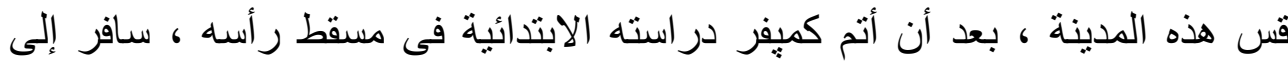

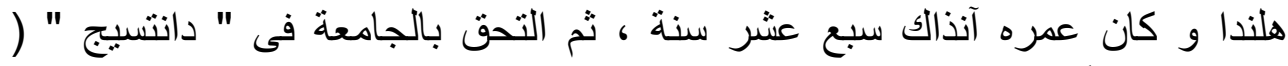

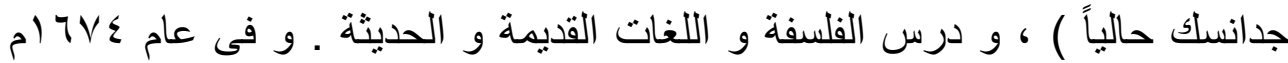

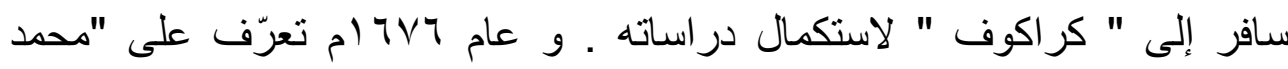

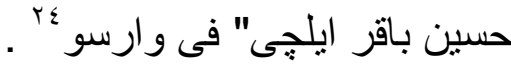

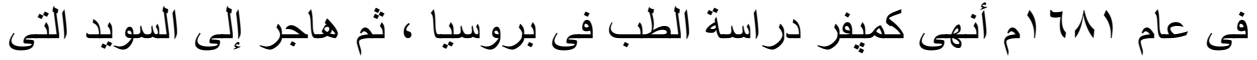

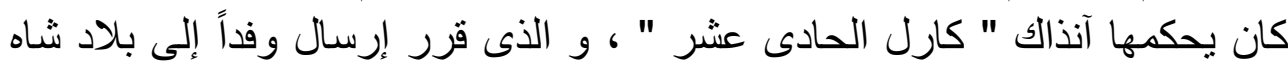

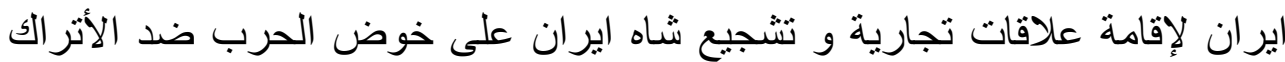

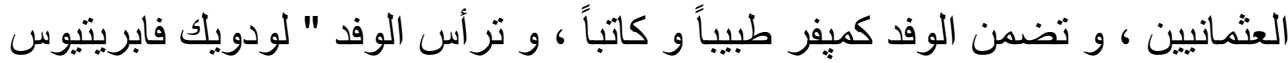

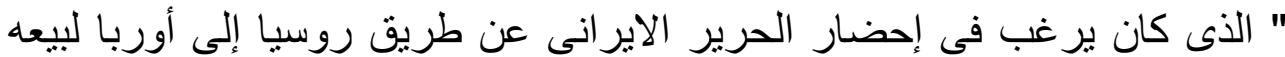

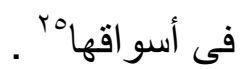

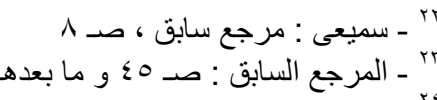

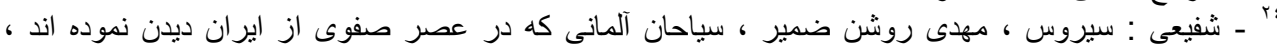

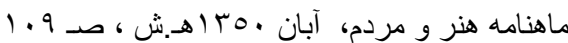

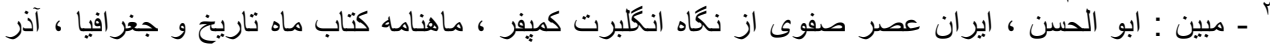




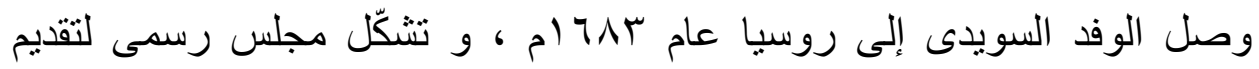

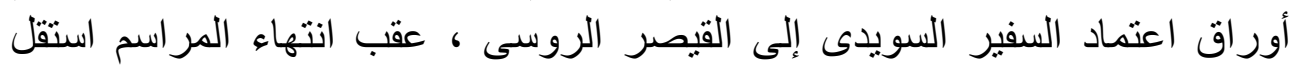

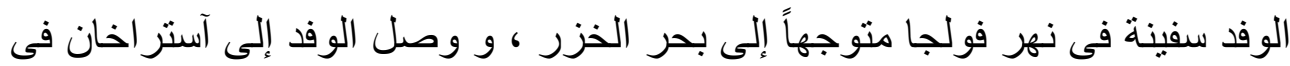

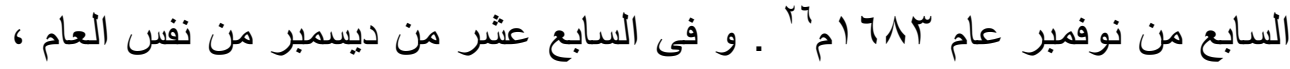

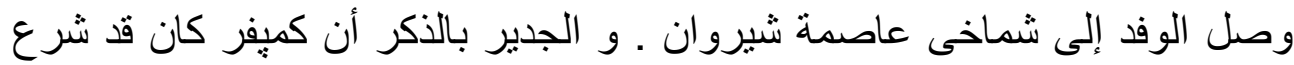

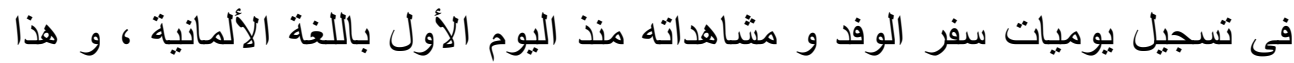

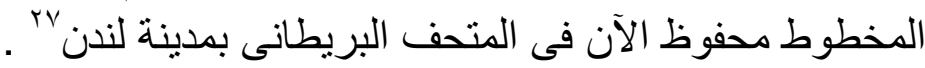

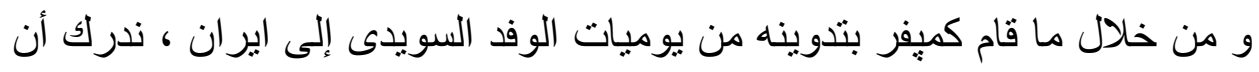

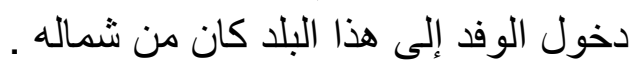

\section{سفرنامهء فلدُ آفاناس يويج كاتُف :}

منذ النصف الثانى من القرن السادس عثر تنامت العلاقات التجارية و السياسية

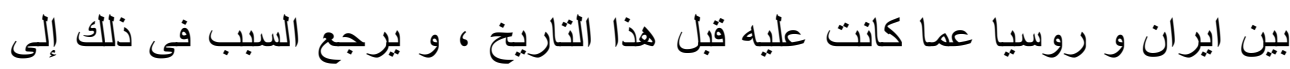

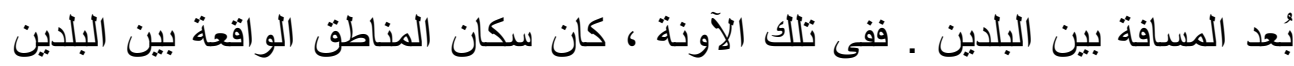

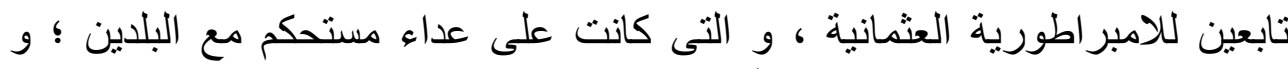

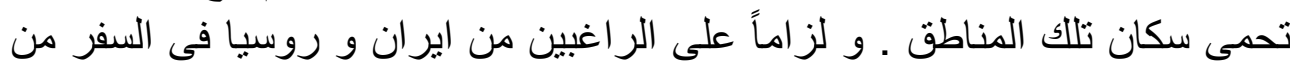

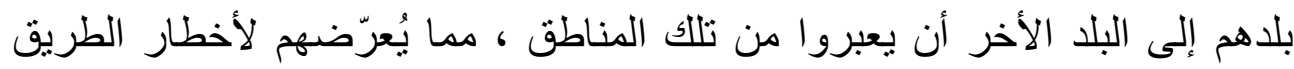

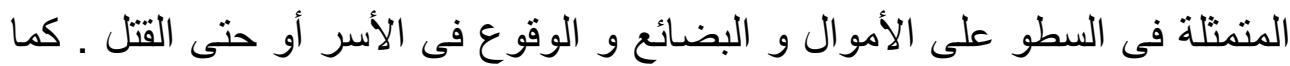

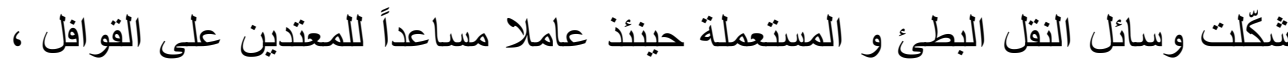

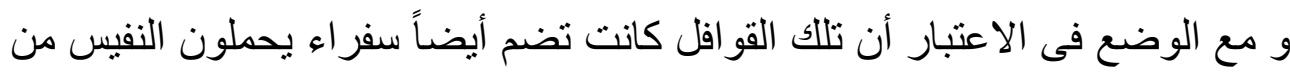

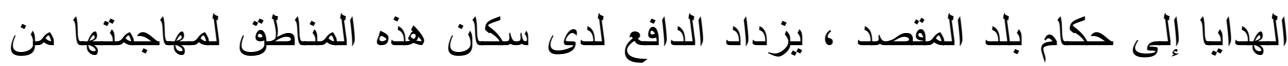

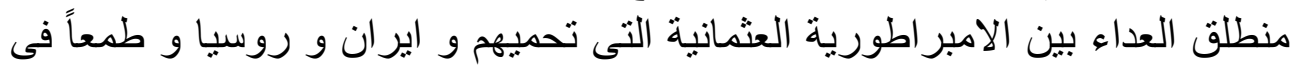

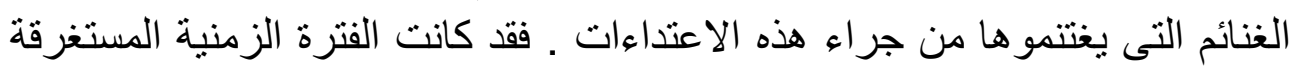

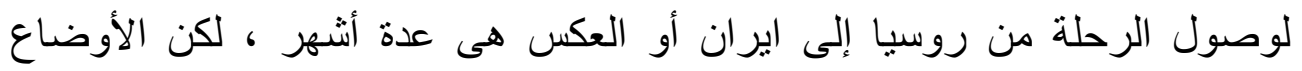

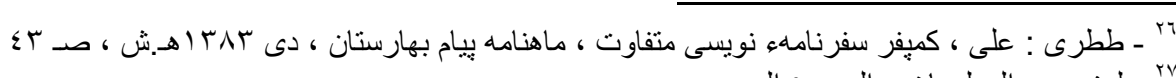

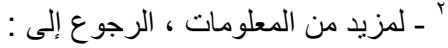

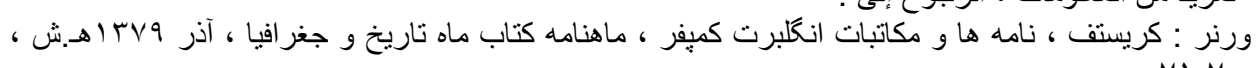
VI عالمى: مهوش ، باغهاى شاهى عهد صفوى و رو ابط آنها با شهر ، مجله معمارى و شهر سازى ، I I Iـ ش. ، 


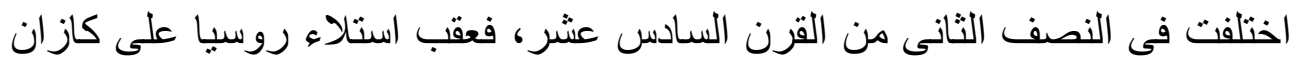

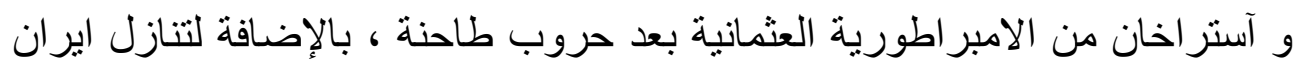

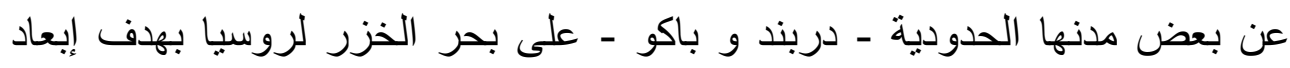

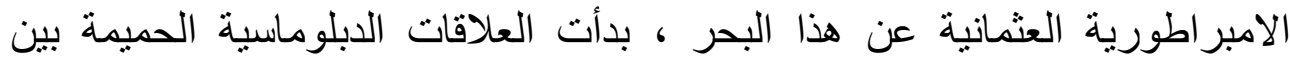

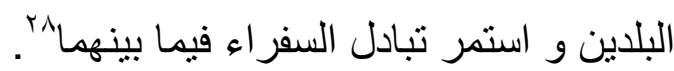

فى ظل حكم الصفويين لايران ؛ تجنبت روسيا الصدام مع ايران حتى لا يتعرض

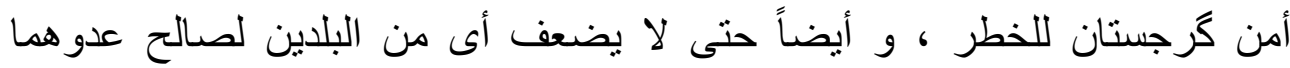

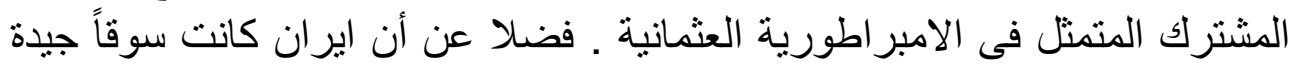

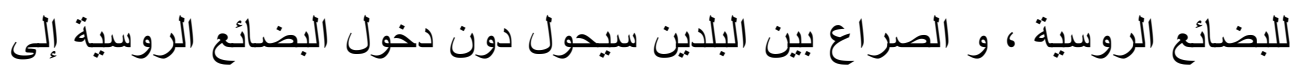

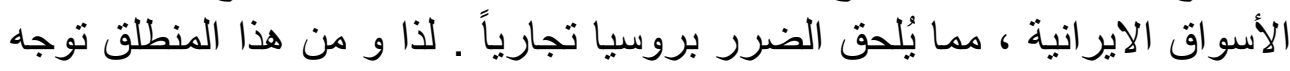

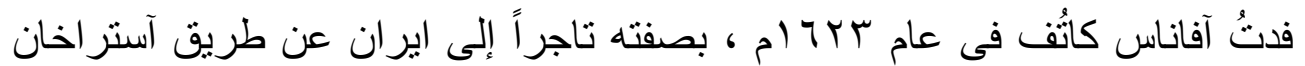

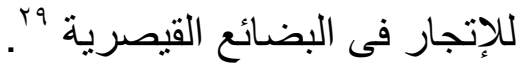

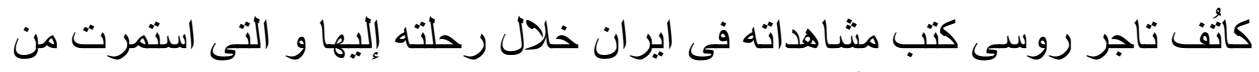

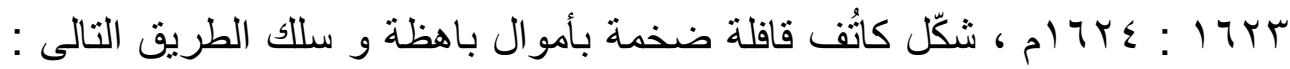

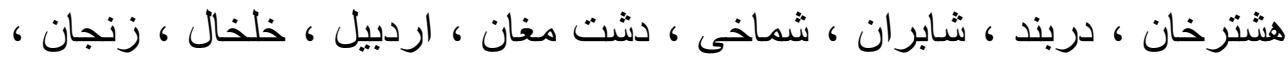

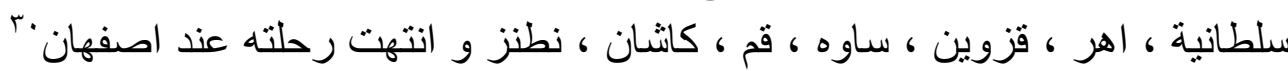

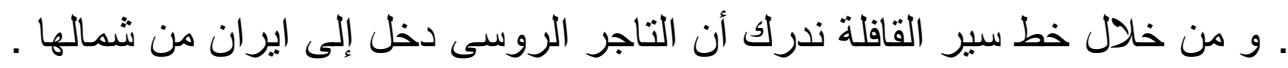

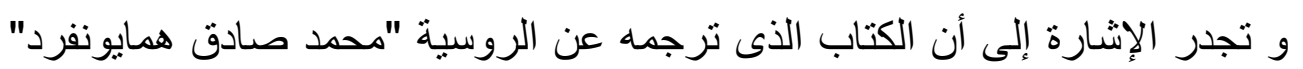

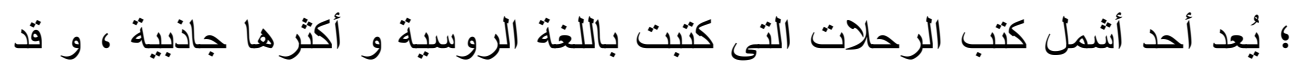

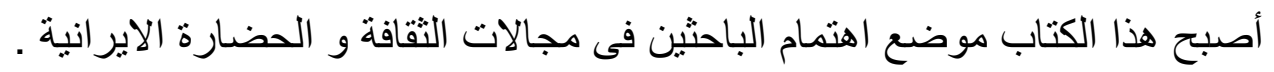

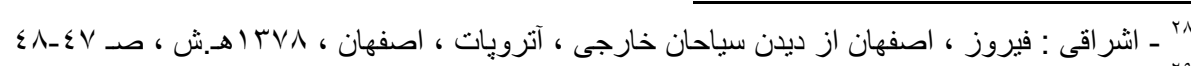
www.radiofarhng.ir

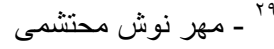

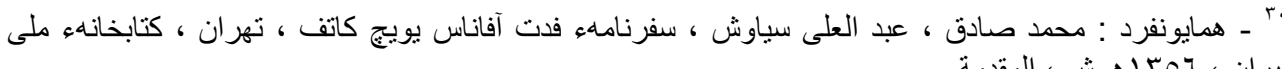




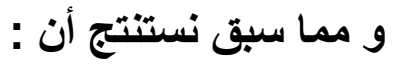

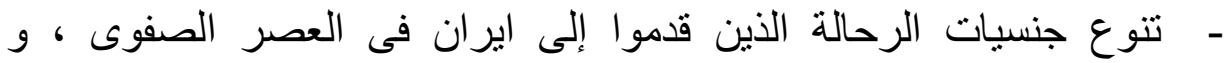

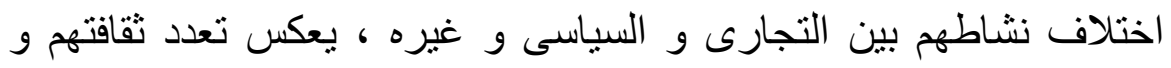

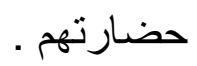

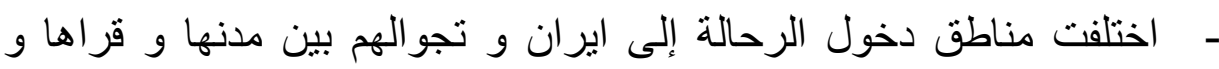

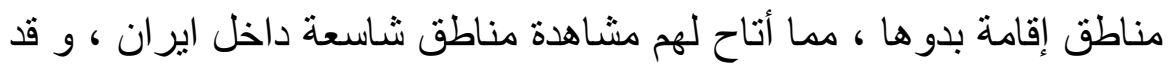

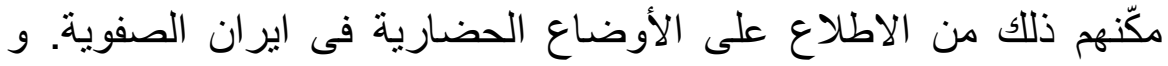

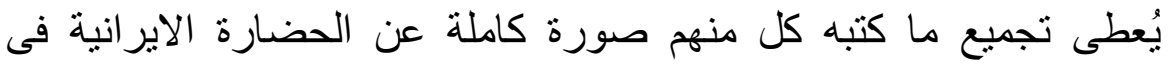

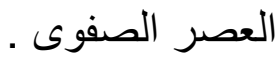

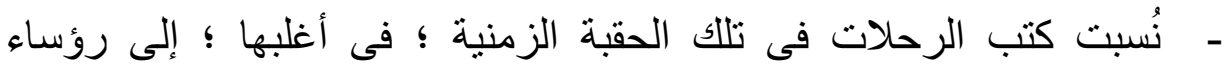

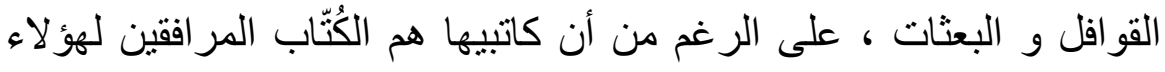

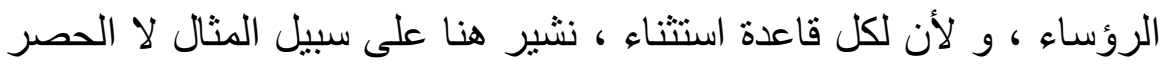

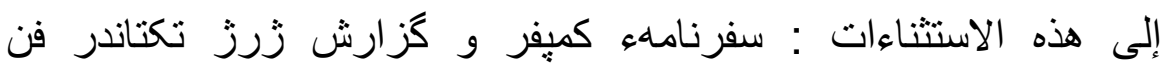

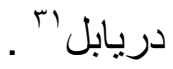
- تمثل هدف الرحالة الأجانب لزيارة ايران فى نقطتين أساسيتين هما : إقامة

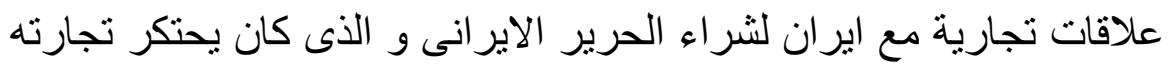

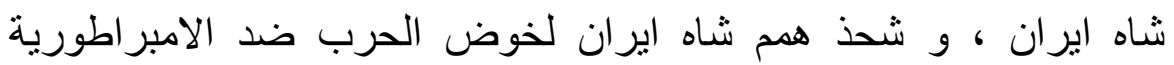

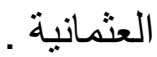

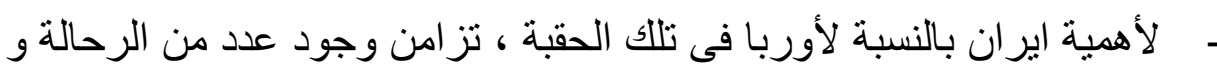

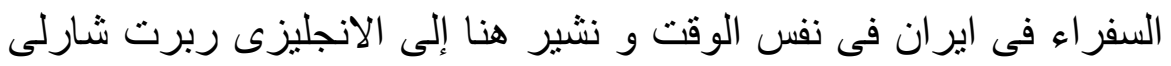

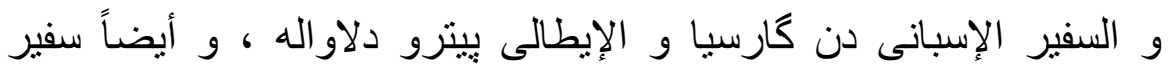

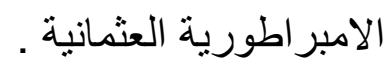




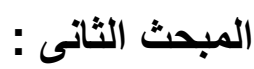

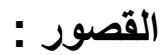

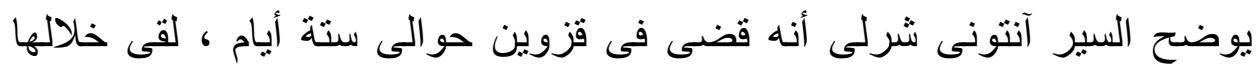

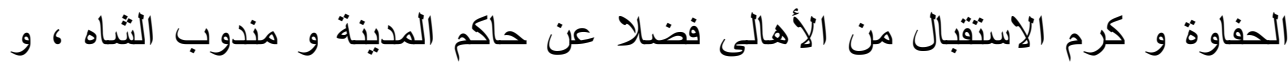

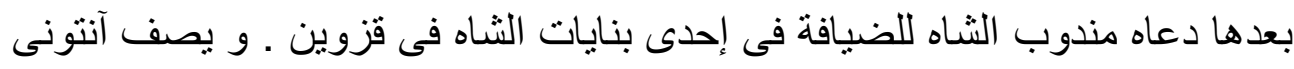

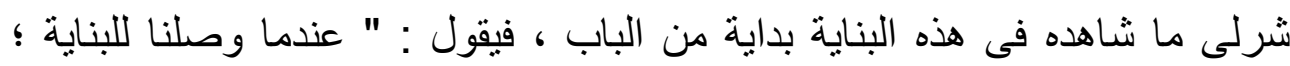

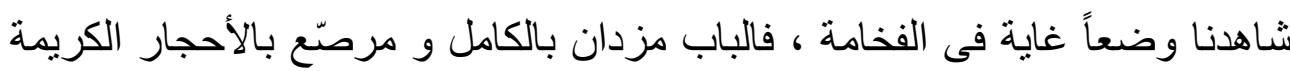

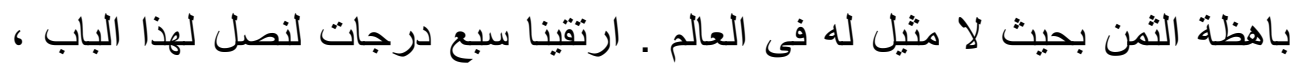

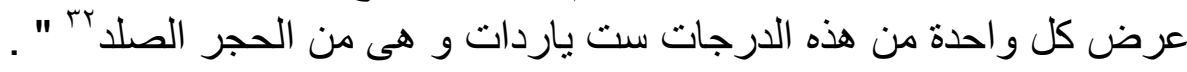

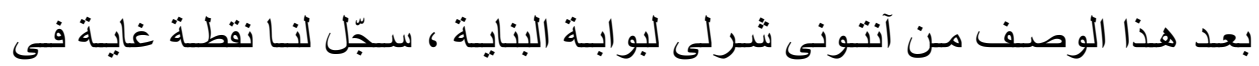

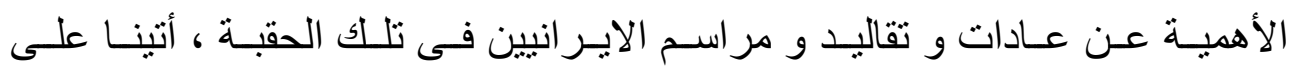

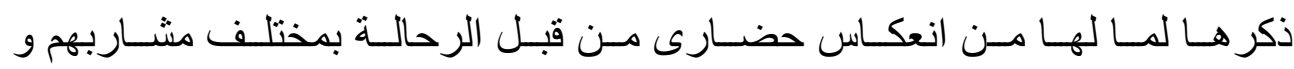

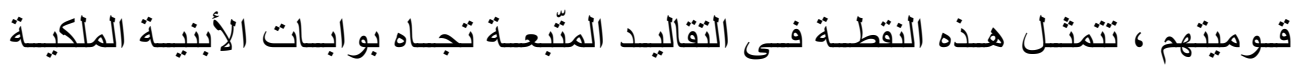

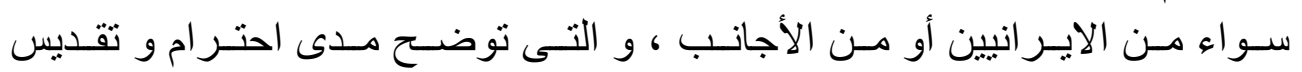

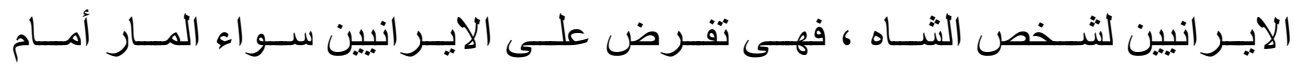

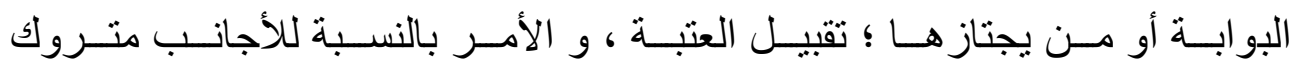

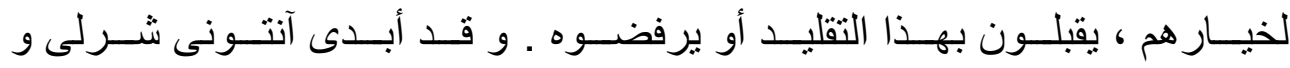

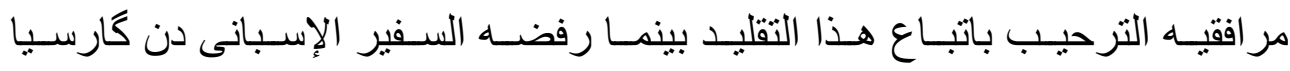

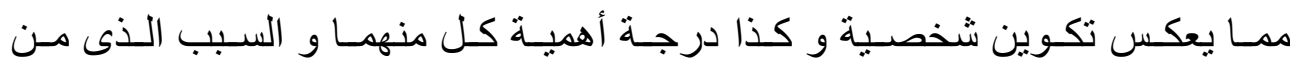

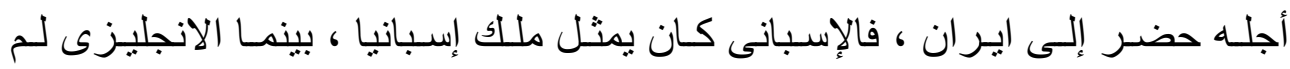

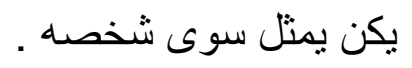

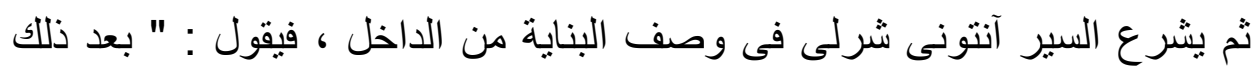

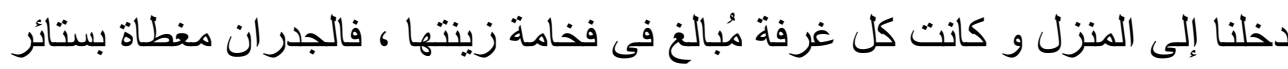

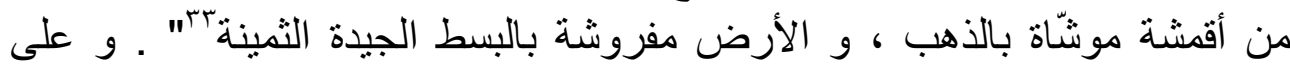

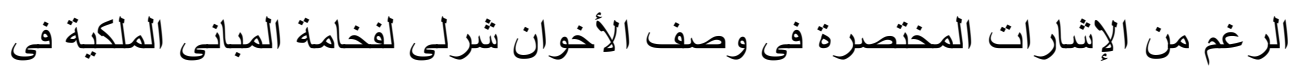


بدايات وصولهم لاير ان ؛ إلا أن هذا الوصف جاء بصورة أكثر اختصراً عقب إرسال

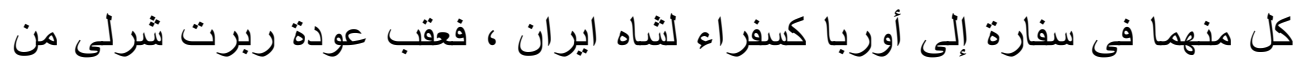

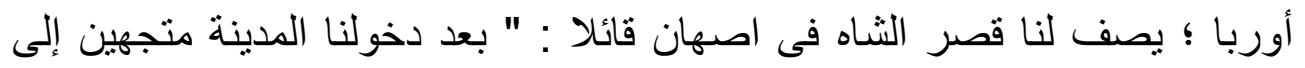

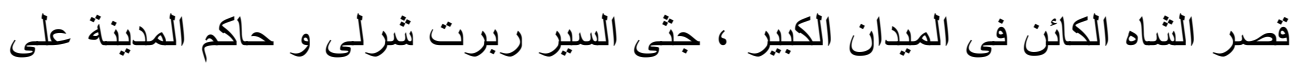

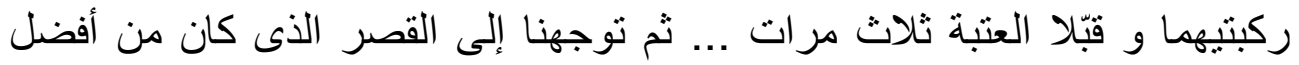

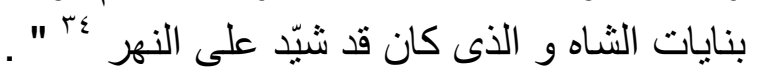

هنا نطرح السؤال النالى : هل اقتصرت الحضارة المعمارية فى ايران الصفوية

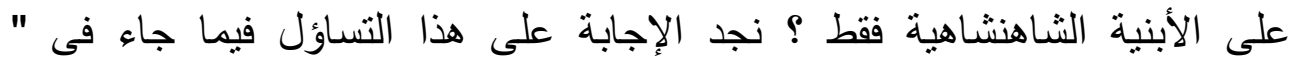

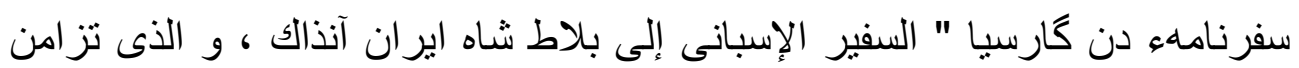

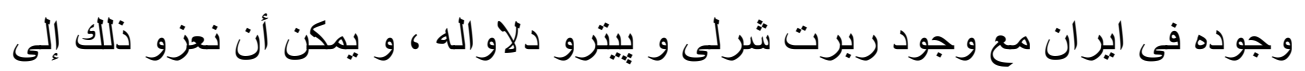

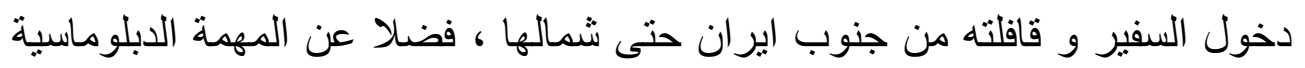

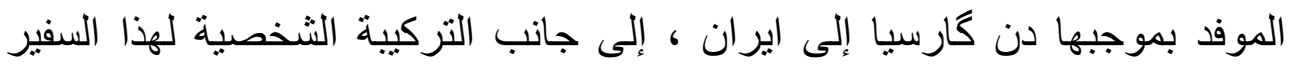

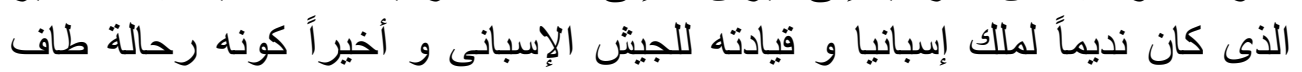

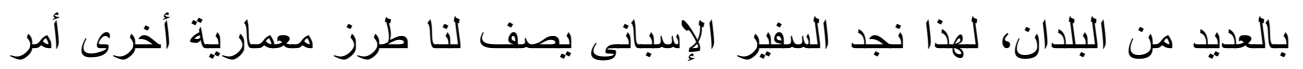
بينائها حكام المدن الاير انية . باندان

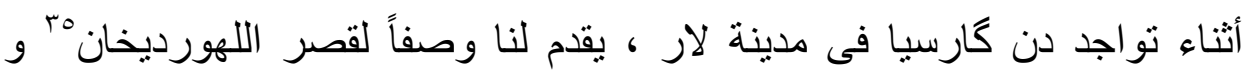

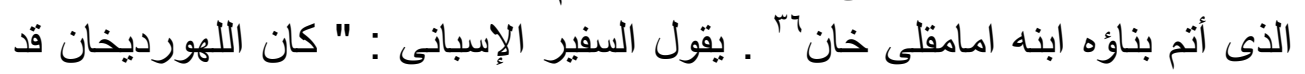

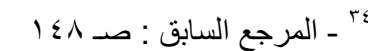

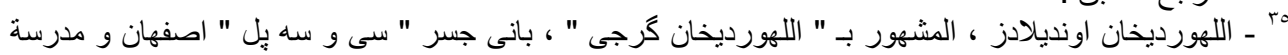

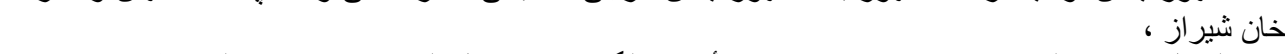

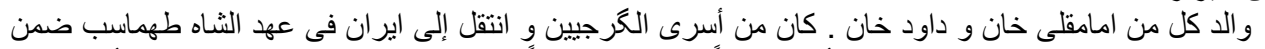

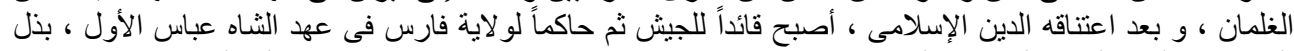

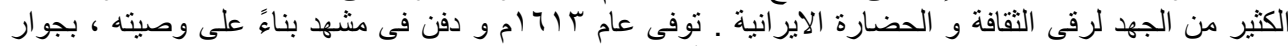

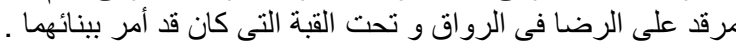

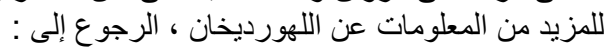

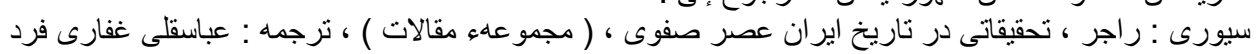

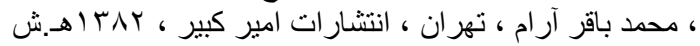

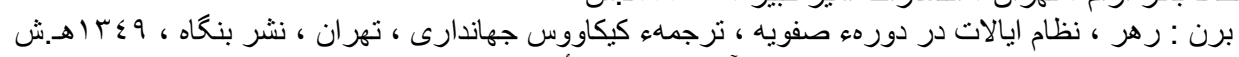

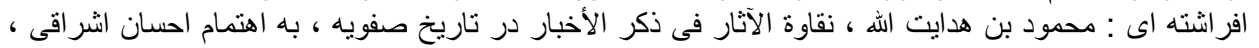

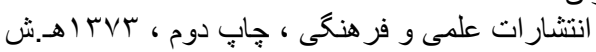
انتشار انتران

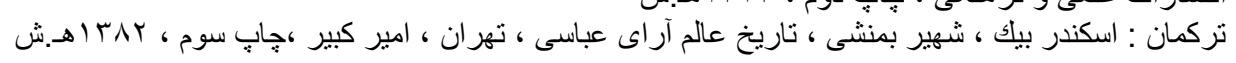




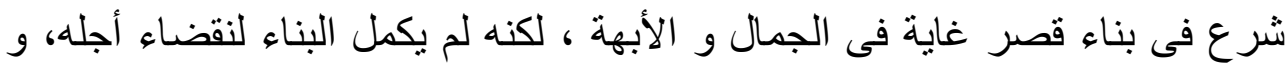

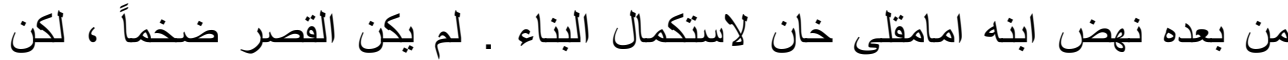

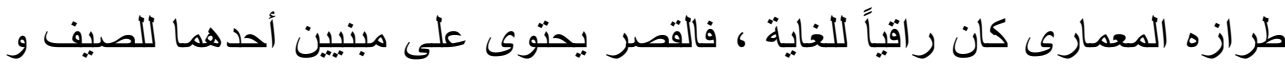

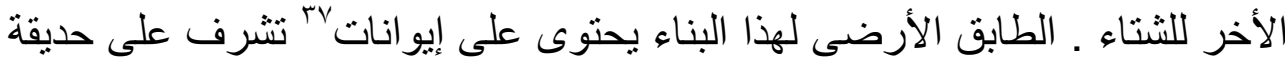

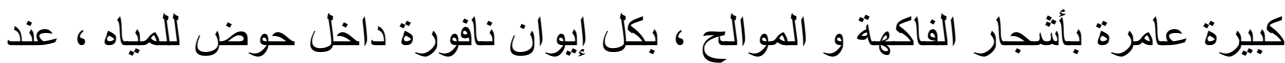

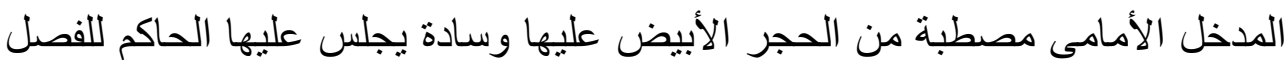

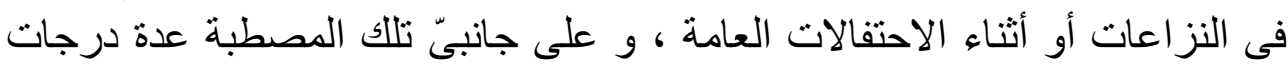

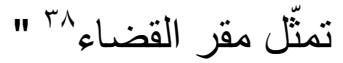

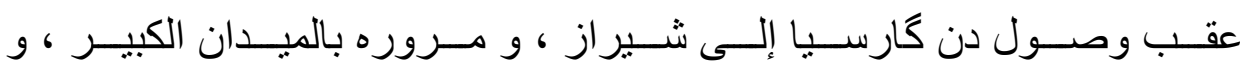

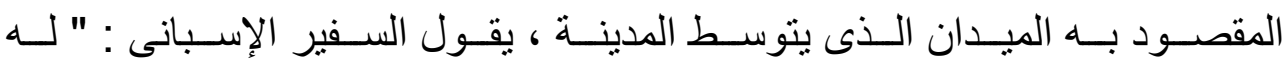

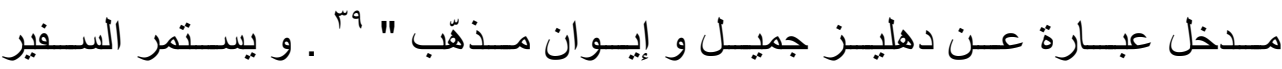

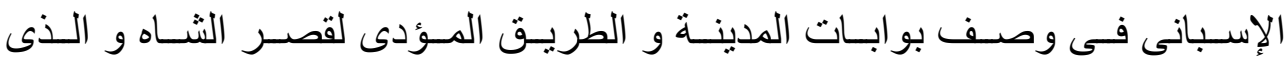

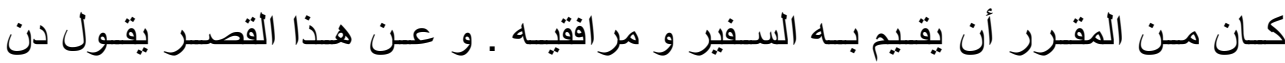

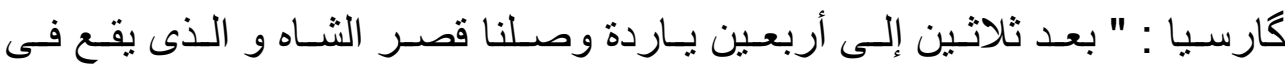

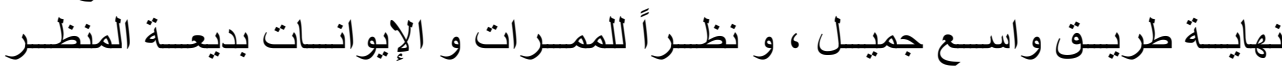

، أنجم يزدى : ملا جلال الدين محمد ، تاريخ عباسى يا روزنامهء ملا جلال ، به كوشش سيف الله وحيدنيا ، تهران

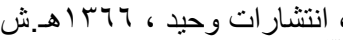

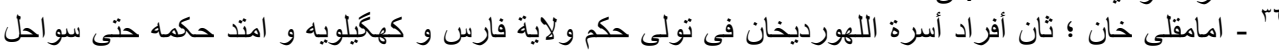

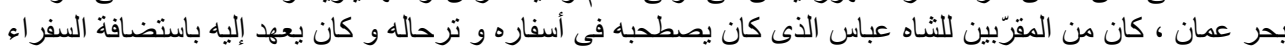

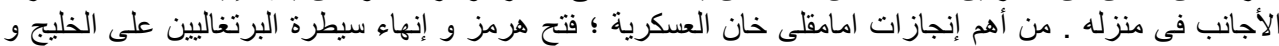

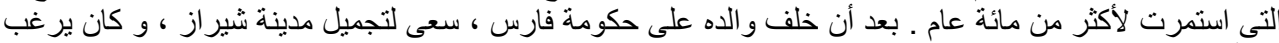

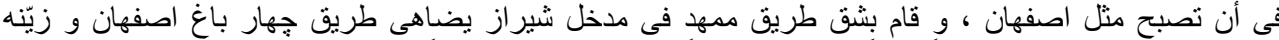

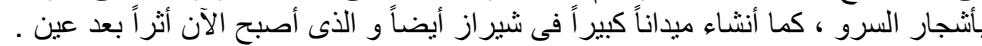

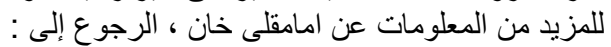

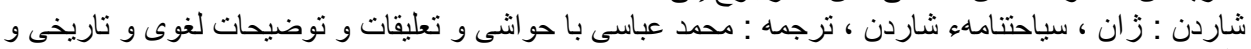

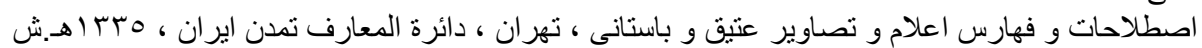

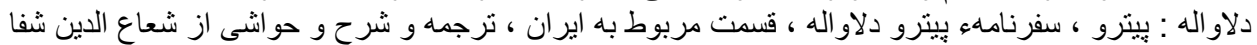

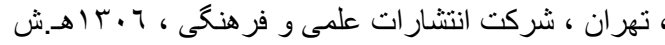

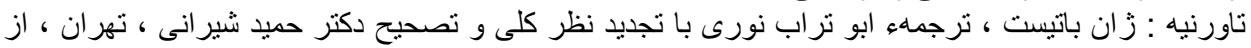

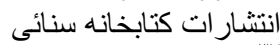

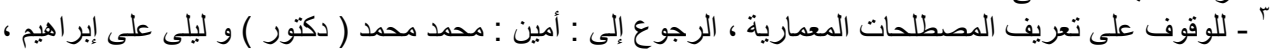

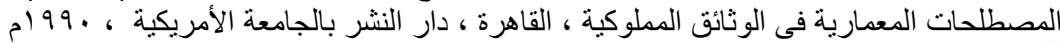

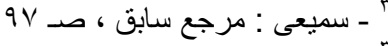

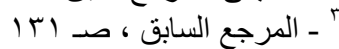




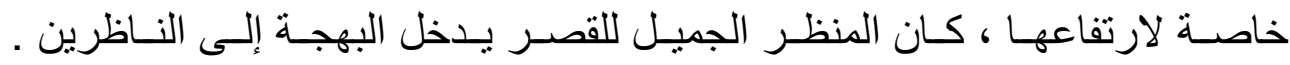

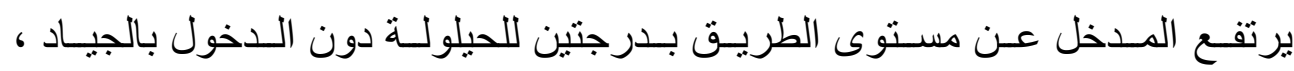

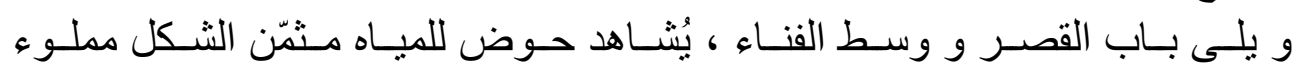

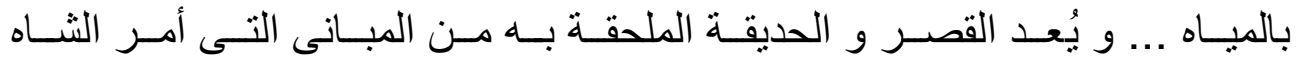

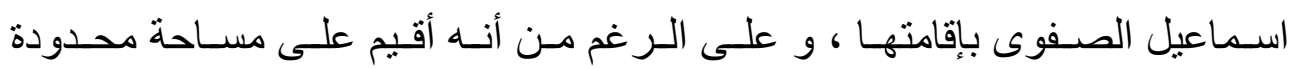

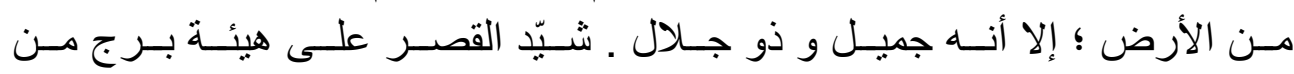

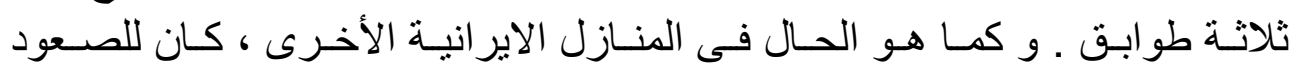

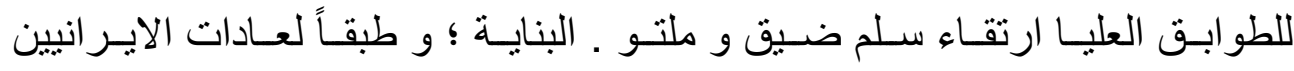

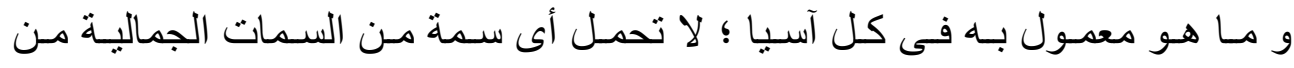

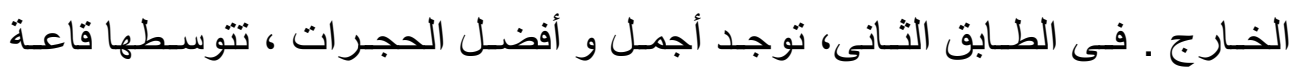

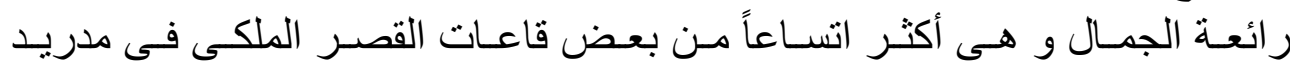

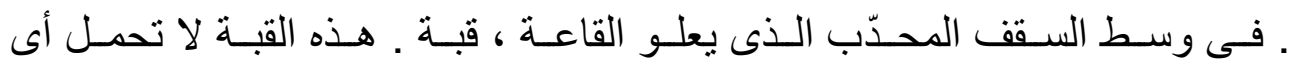

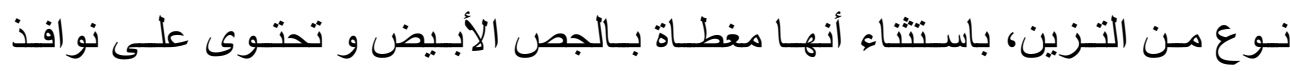
زجاجية لتوفير الإضـاءة . بان.

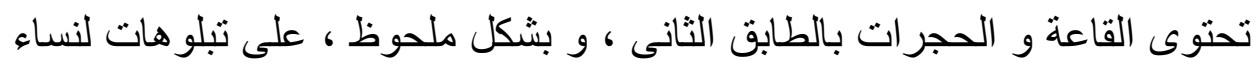

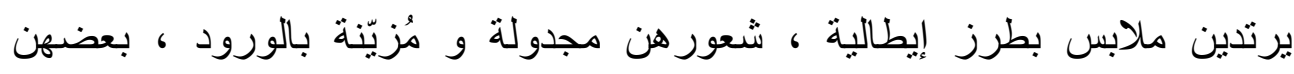

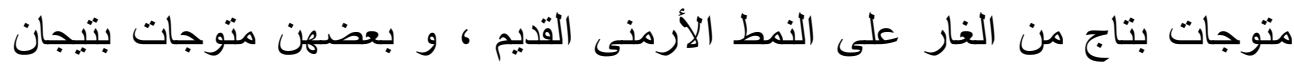

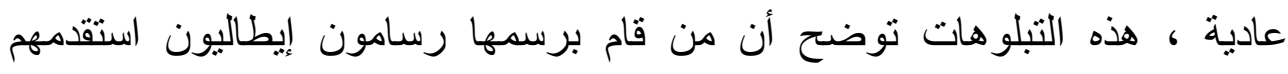
الفينسيون للثشاه .

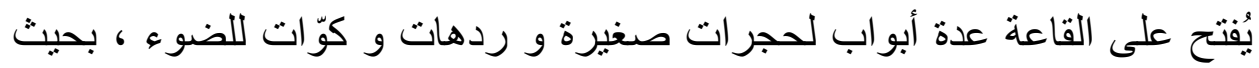

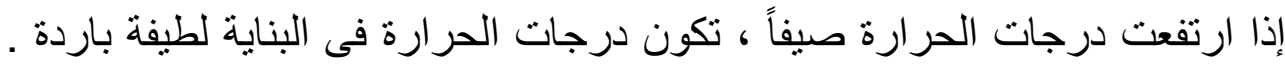

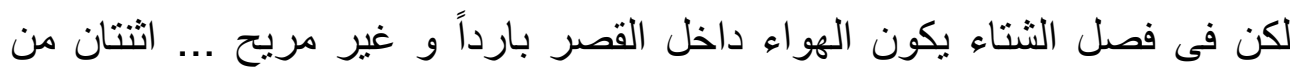

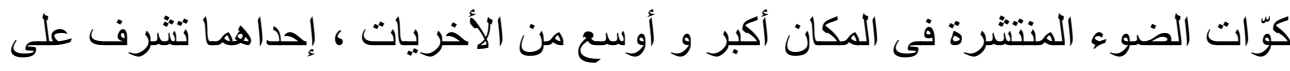

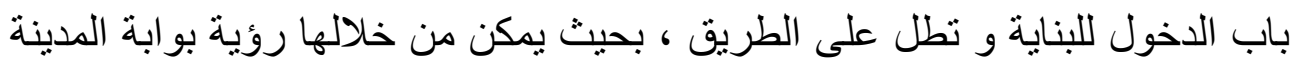

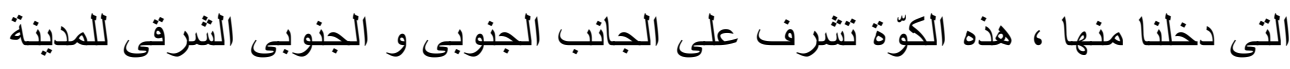

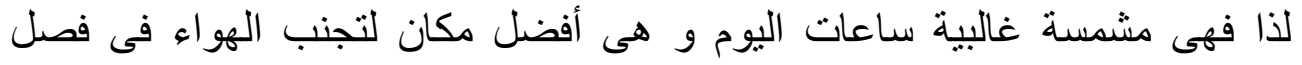

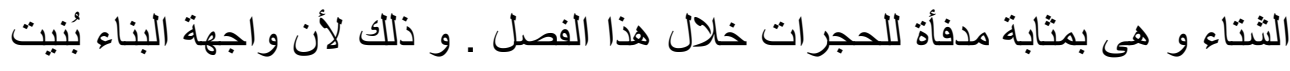

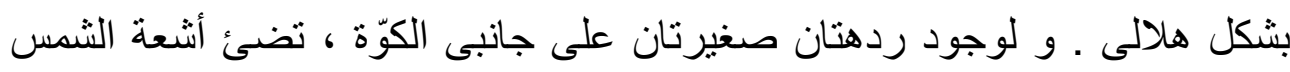




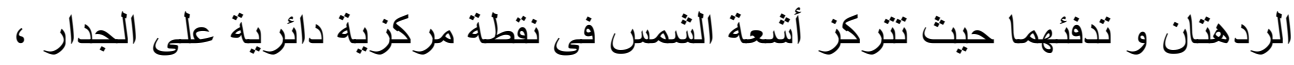

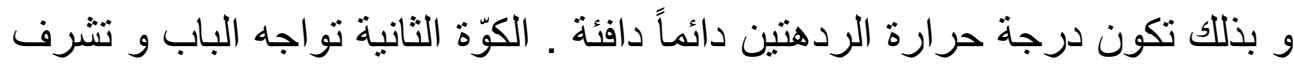

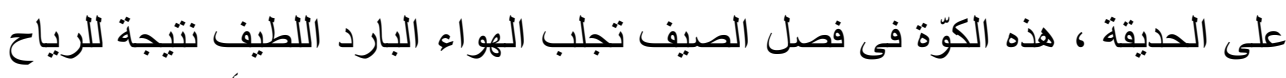

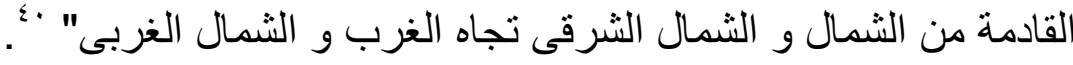

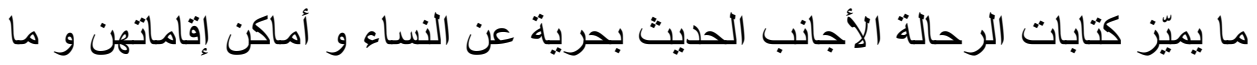

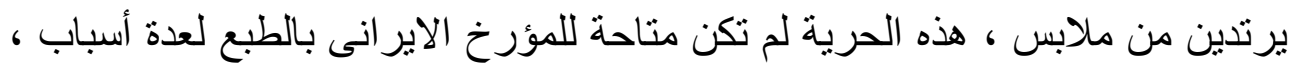

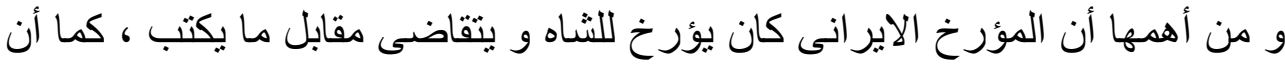

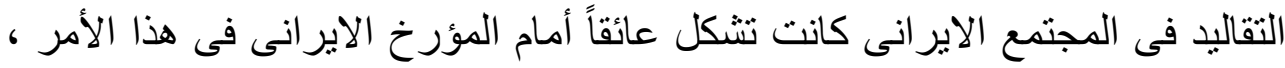

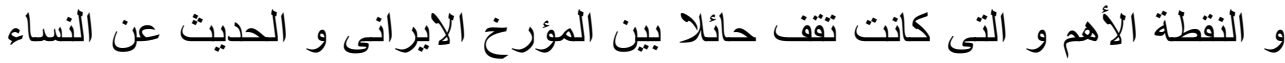

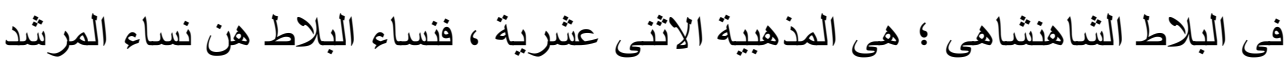

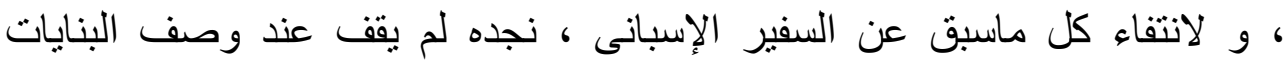

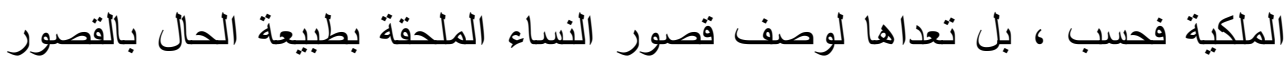

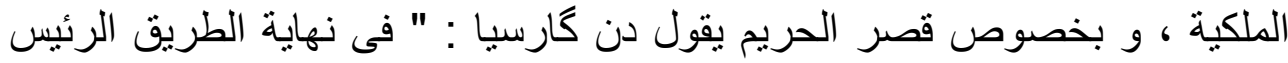

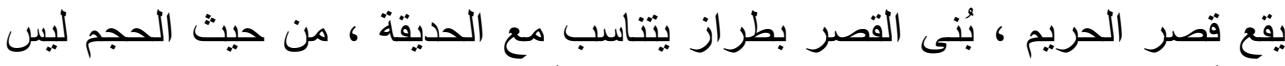

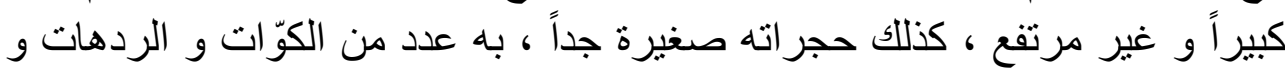

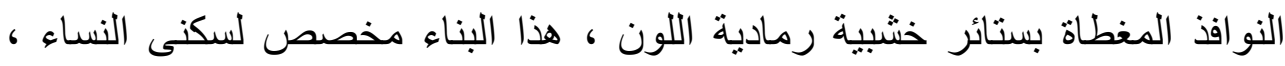

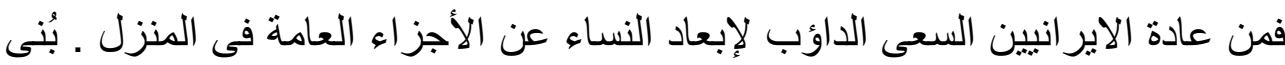

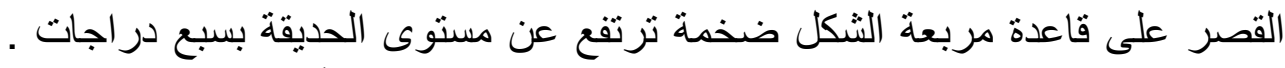

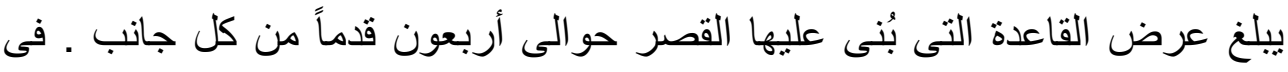

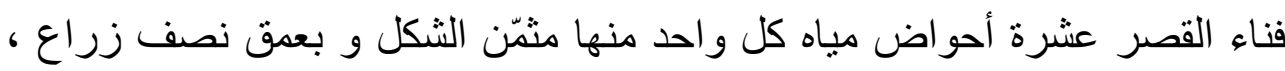

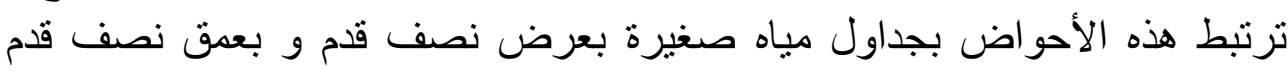

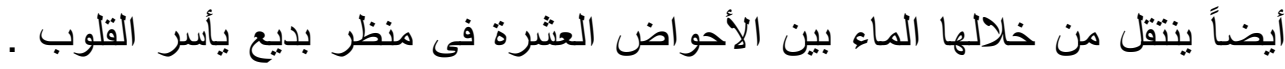

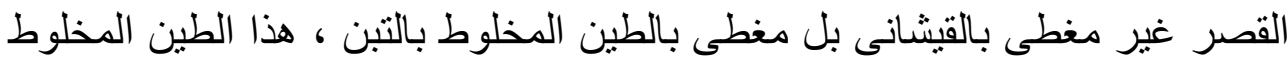

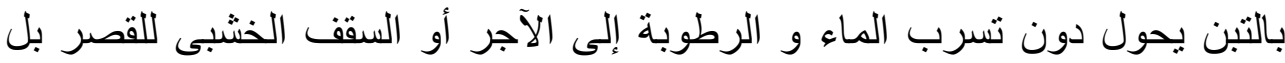

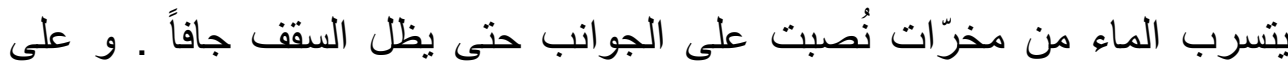

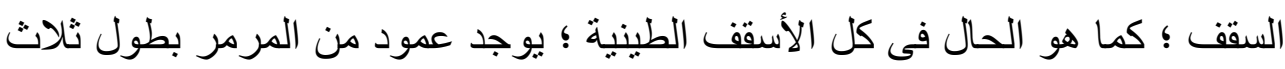

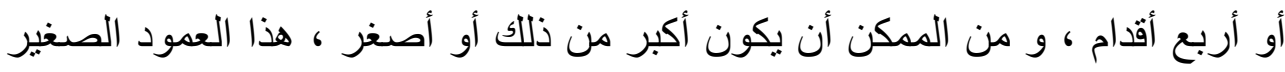


لتنقية و خلط الطين الجديد بالتبن و الذى يضاف بصورة دورية إلى الخليط القديم ـ و

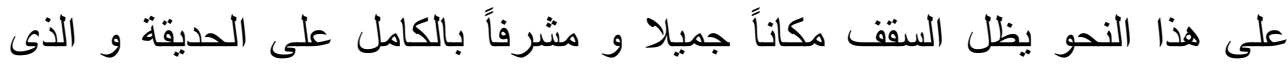

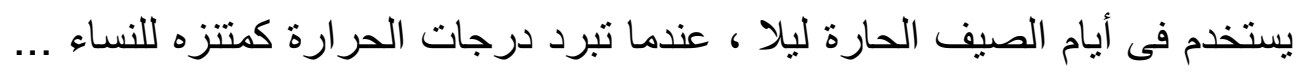

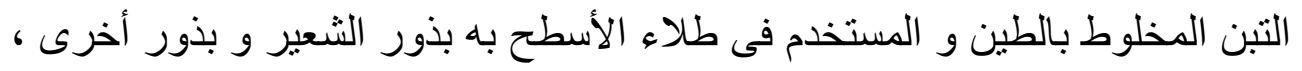

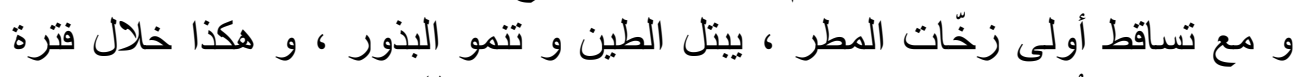

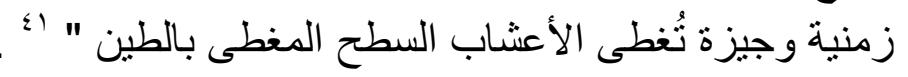

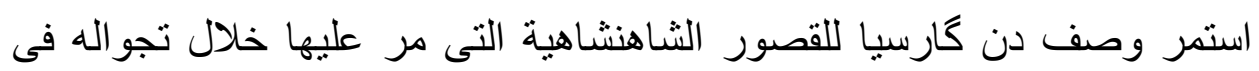

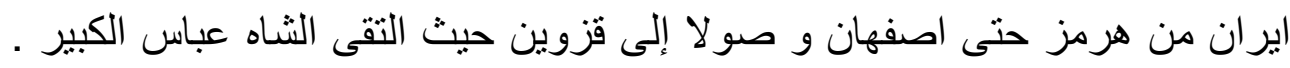

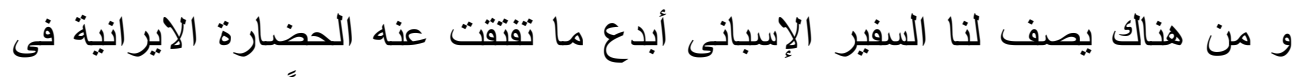

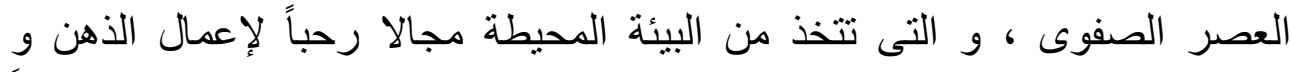

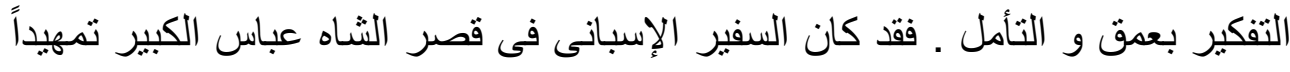

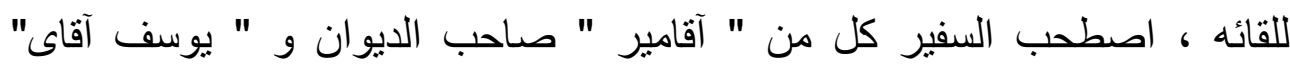

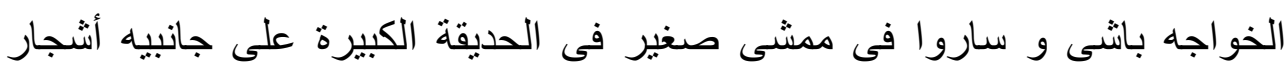

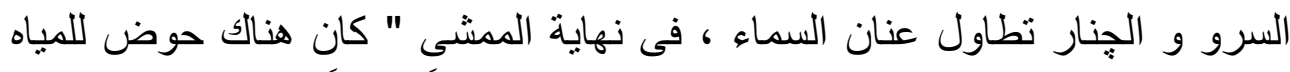

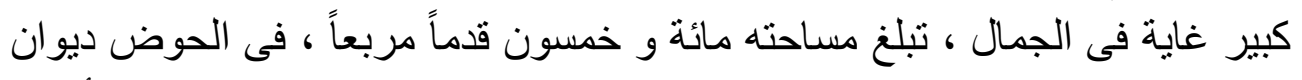

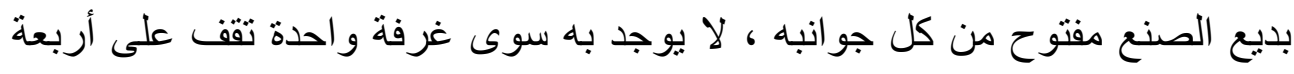

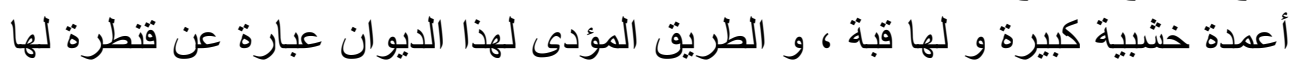

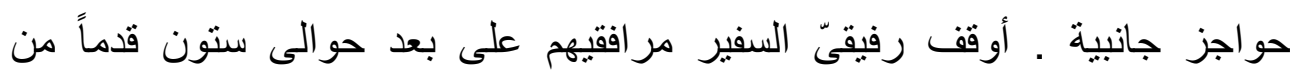

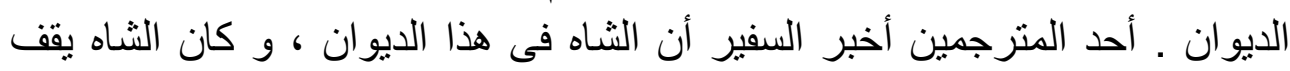

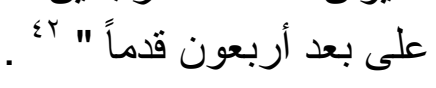

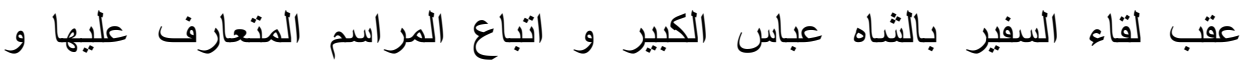

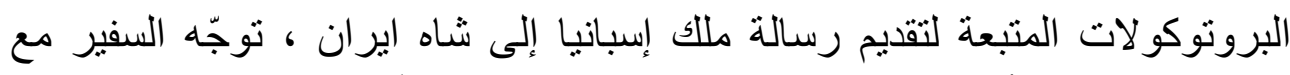

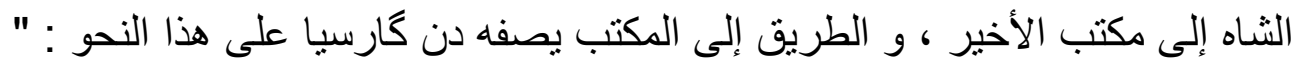

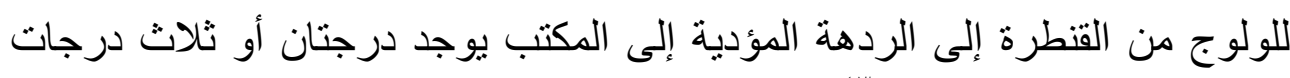

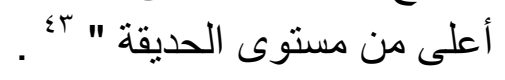

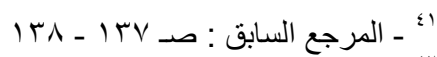

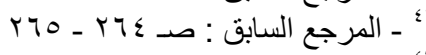

$$
\begin{aligned}
& \text { r ـ المرجع السابق : صـ }
\end{aligned}
$$


هكذا نلحظ أن السفير الإسبانى قد قطع مسافة كبيرة داخل ايران من هرمز إلى إلى

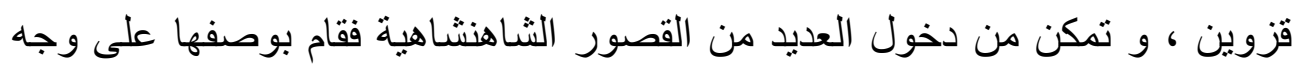

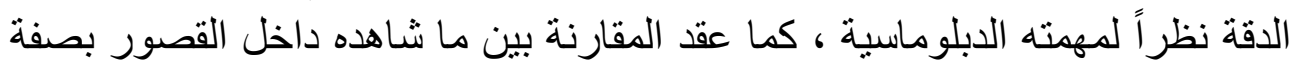

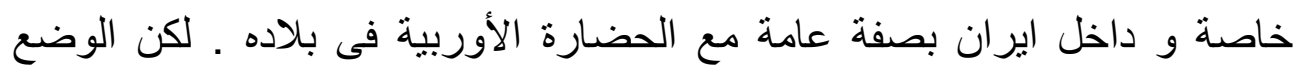

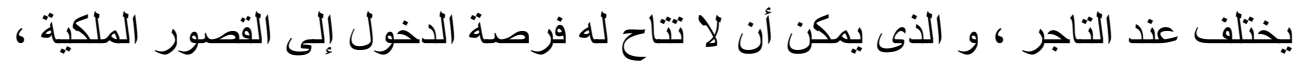

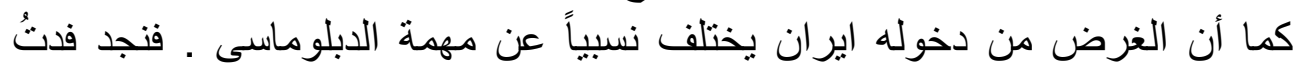

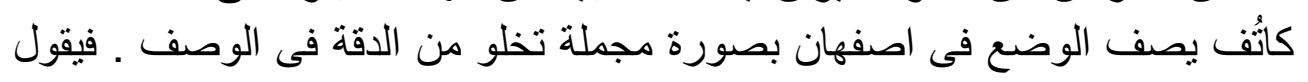

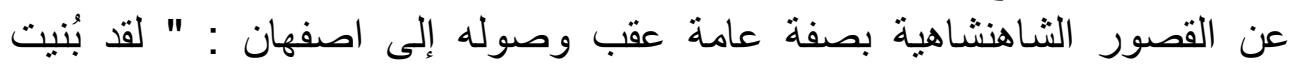

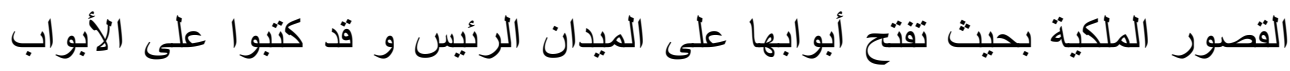

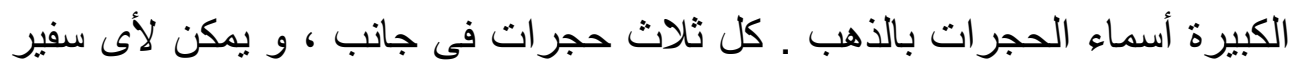

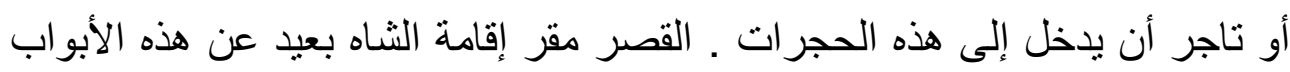

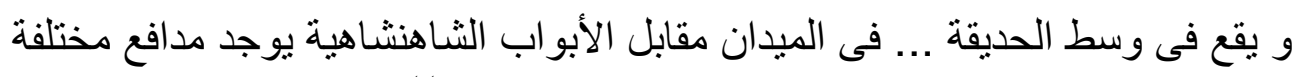

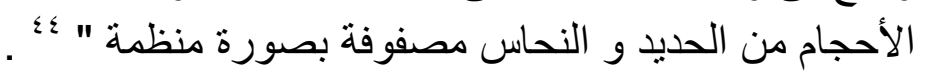

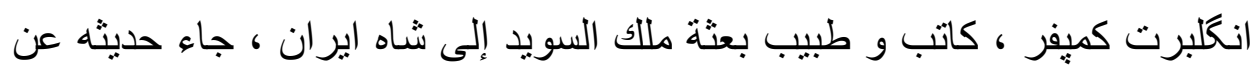

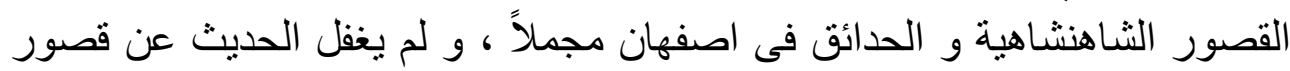

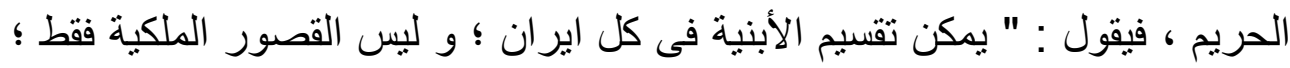

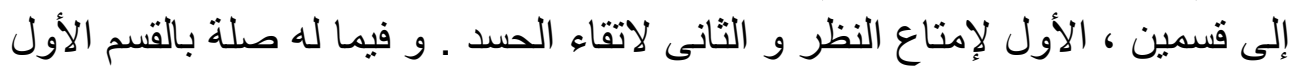

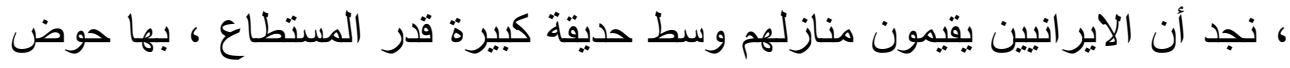

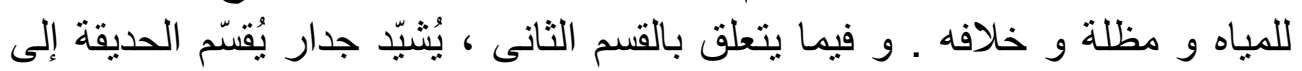

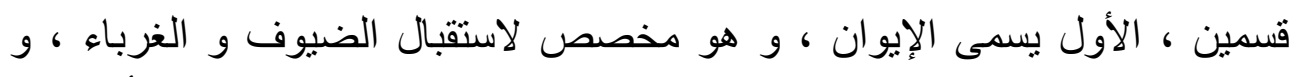

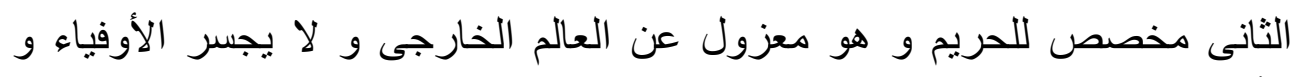

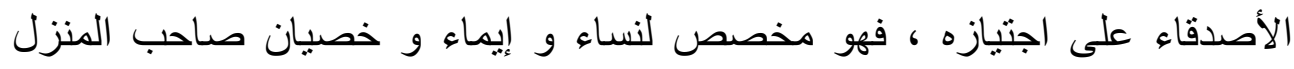

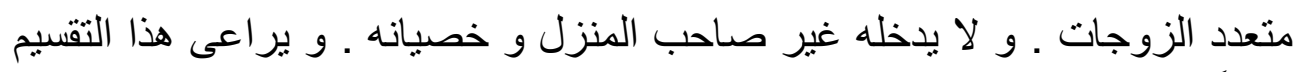

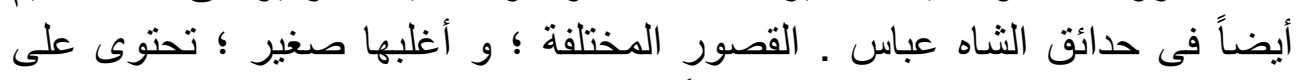

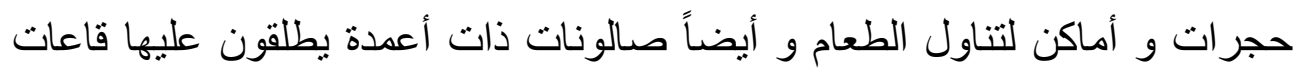

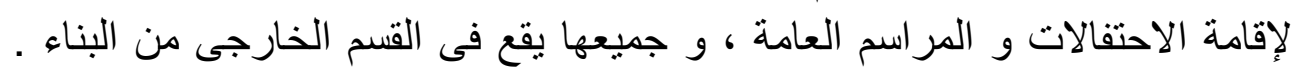




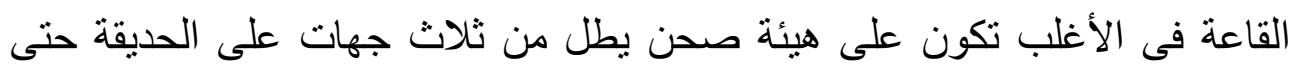
يتمتع ضيوف الثناه بمنظر الحديقة المبهج دون مانع أو عائق . أما قصر الحريم ، فبالإضافة إلى ما جئنا عليه ، فهو بناء يحتوى على الكثير من

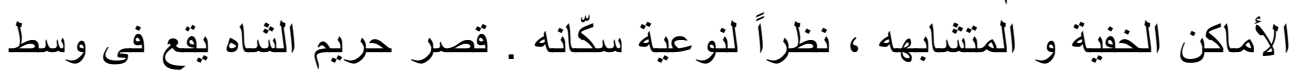

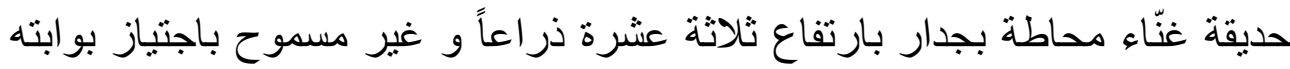

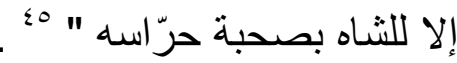

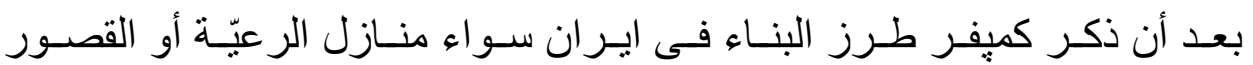

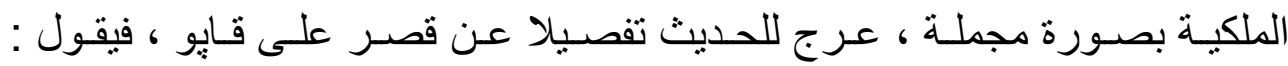

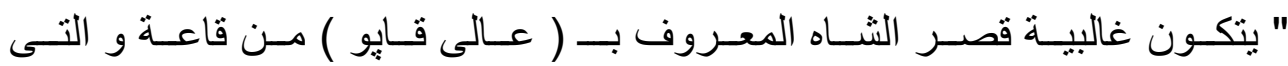

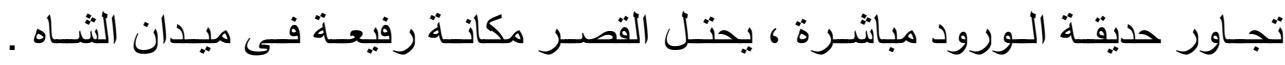

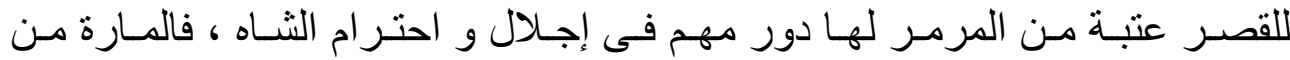

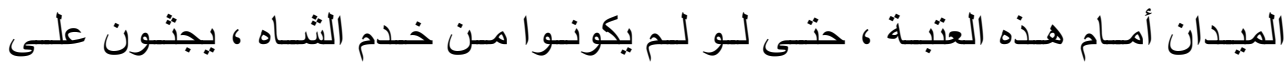

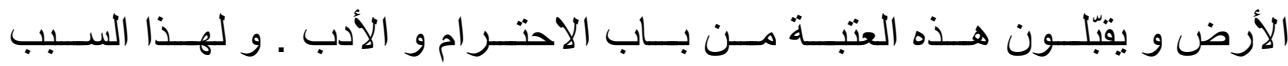

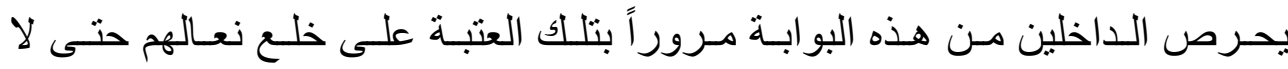

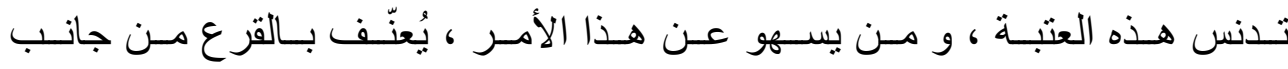

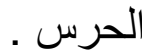

يلى البوابة طريق بطول مائتى قدم مغطى بالحصى الصغير و على جانى جانبيه جدار

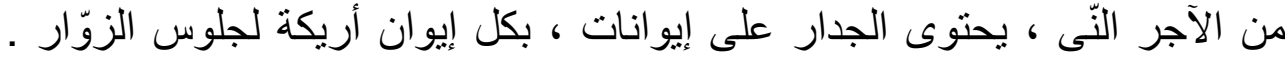

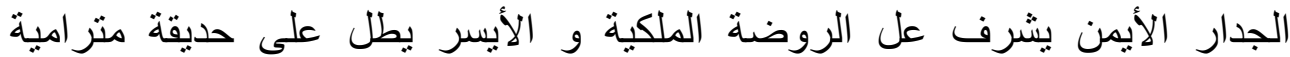

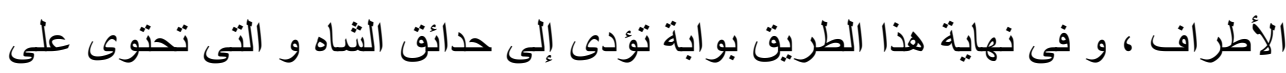

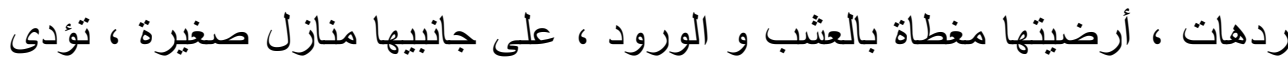

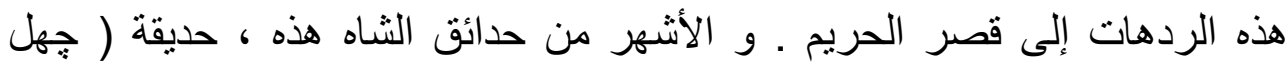

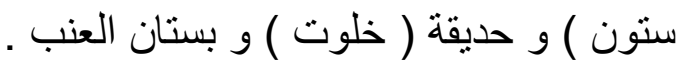

أما قصر عالى قايو فيقبع على دذخله مدفعان قديمان على قاعدتين ، أحدهما Ballestriari

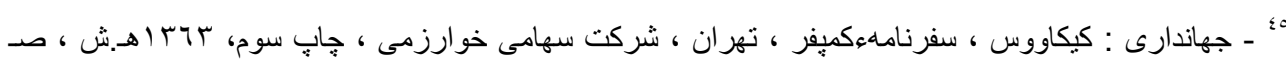

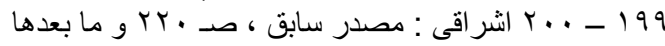




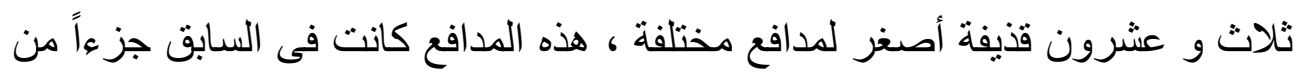

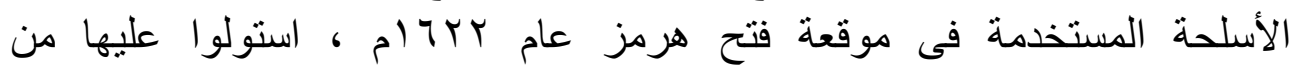

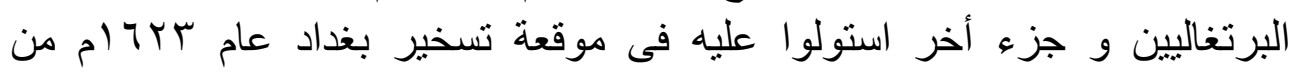

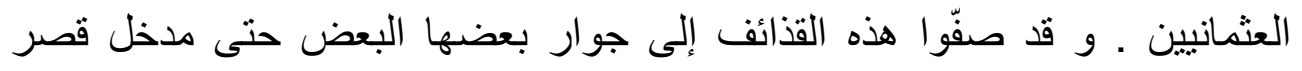

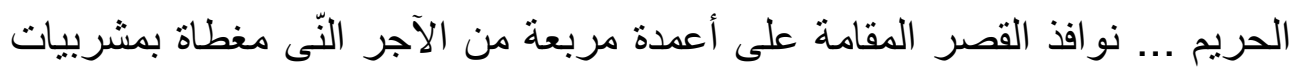

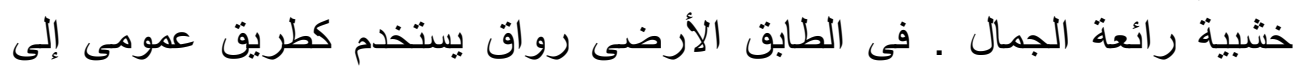

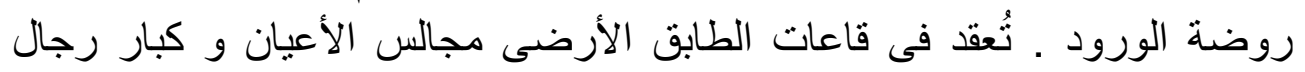

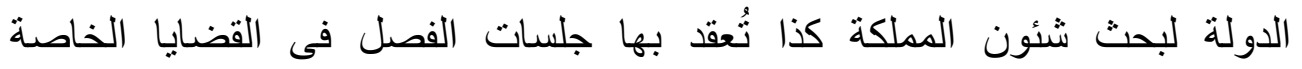

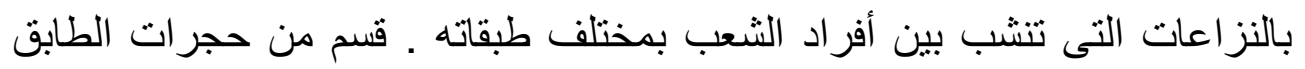

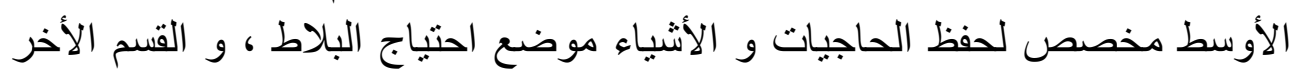

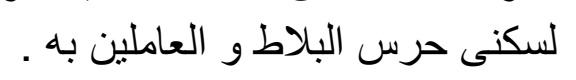

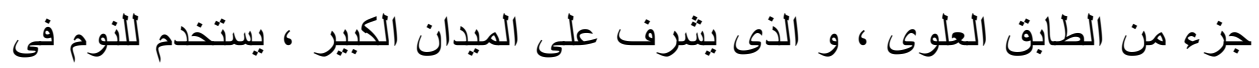

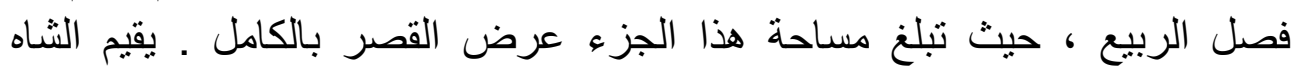

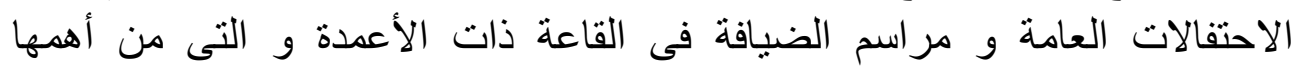

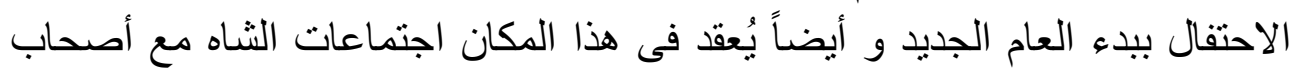

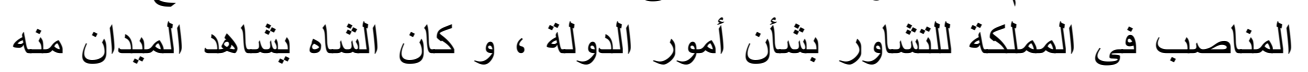

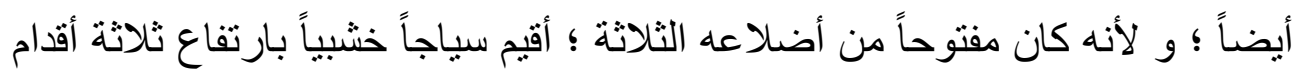

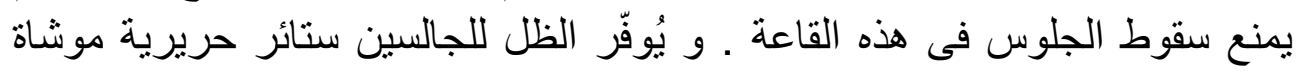
بالورود .

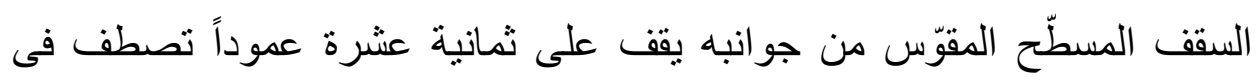

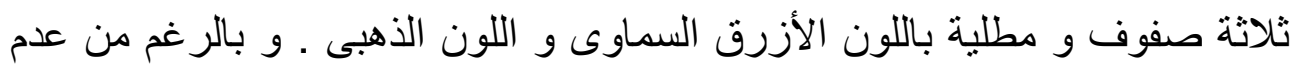

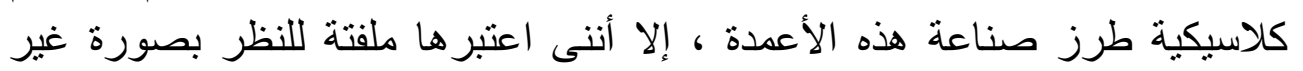

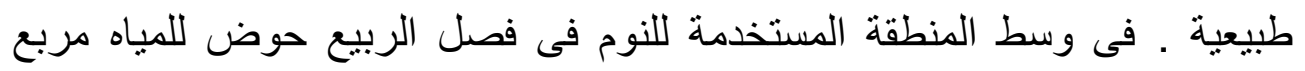

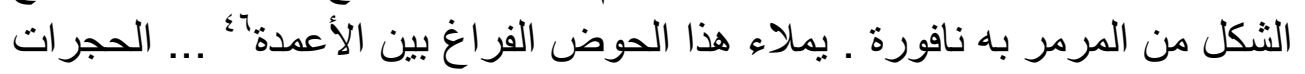


فى الجزء الخلفى فى الطابق العلوى و المقامة على صفين مقصورة على الثاه و

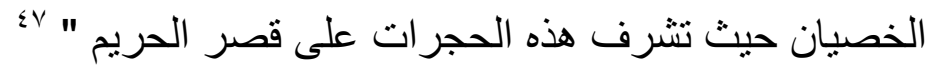

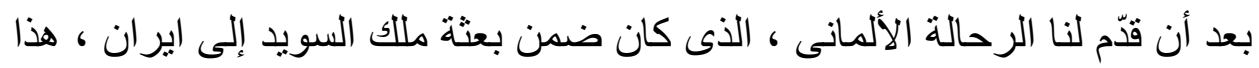

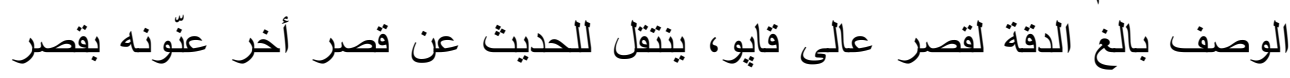

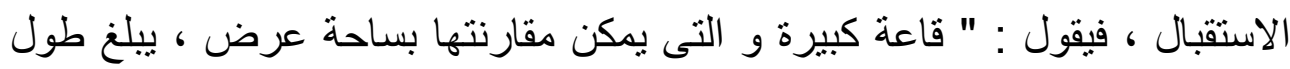

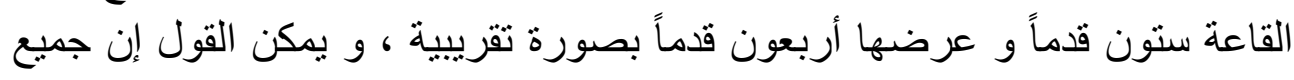

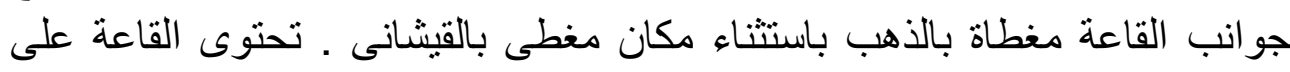

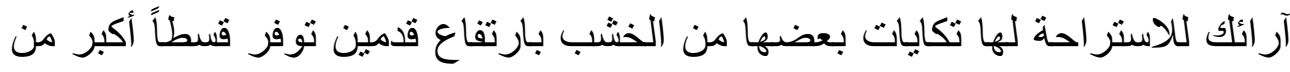

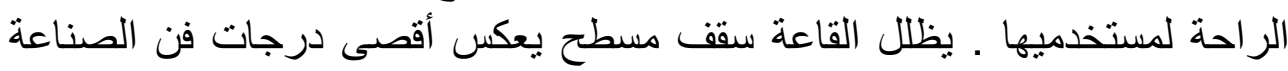

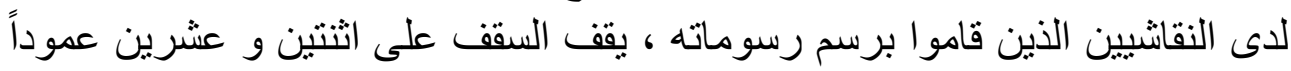

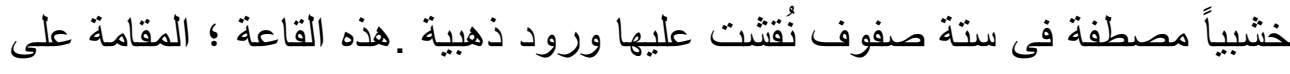

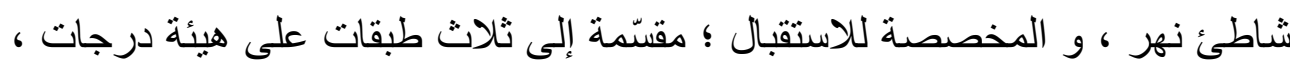

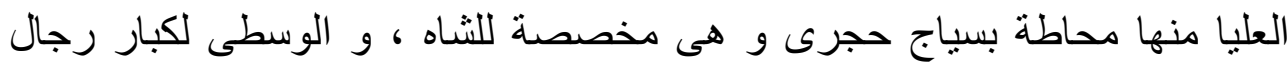

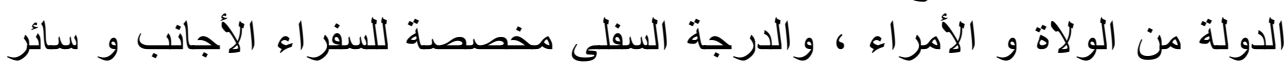

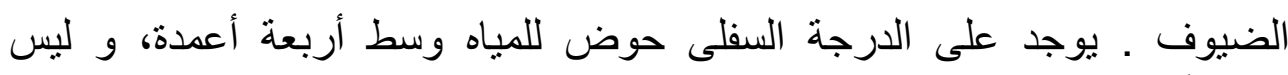

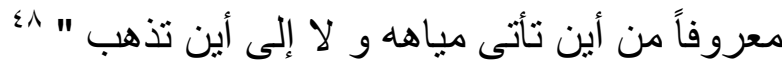

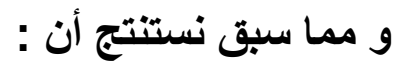

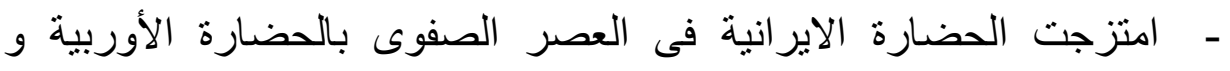

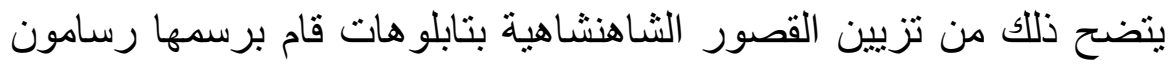

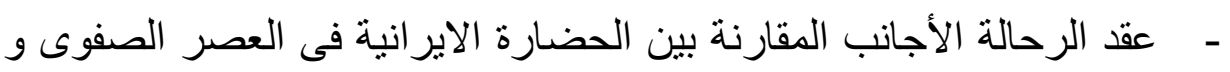

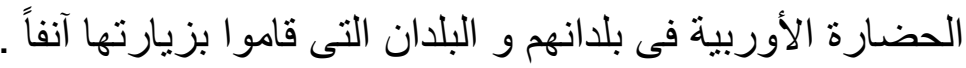

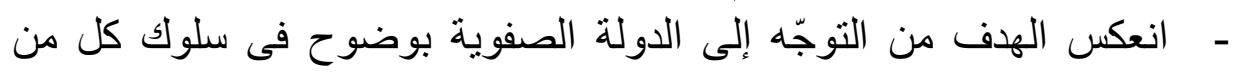

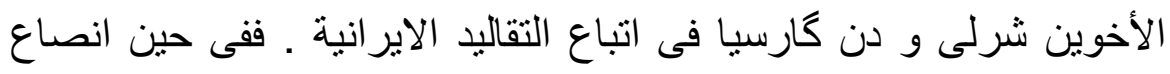


الانجليز لتطبيق هذه التقاليد ، و المتمثلة فى تقبيل عتبة القصر الثـاهنشاهي،

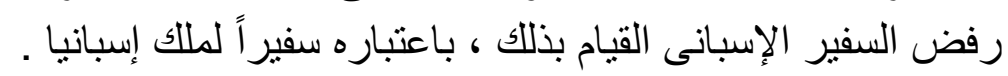

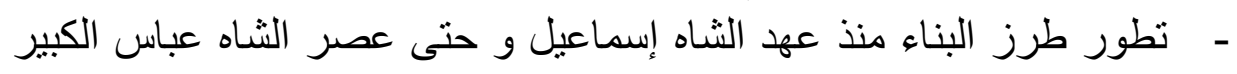

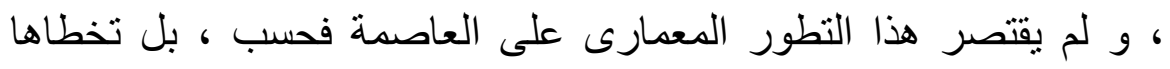

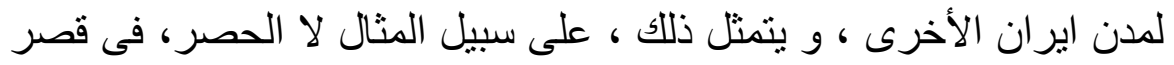

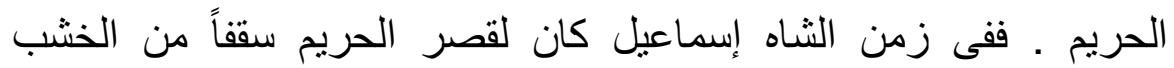

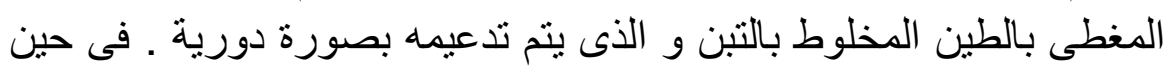

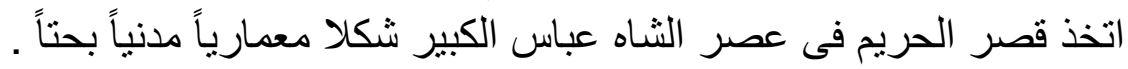

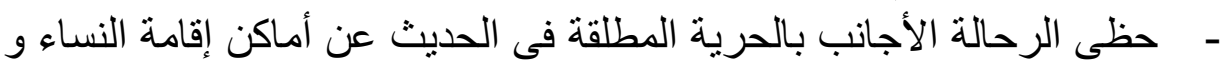

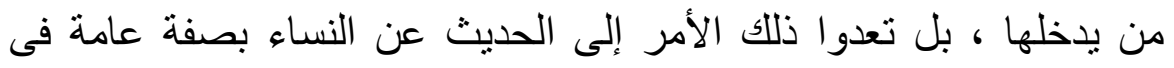

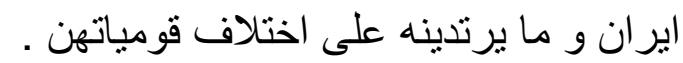

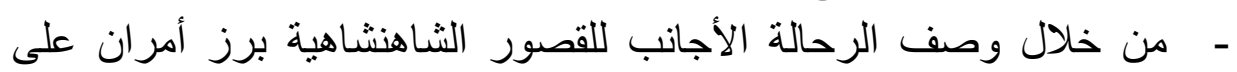

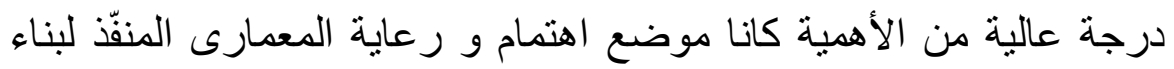

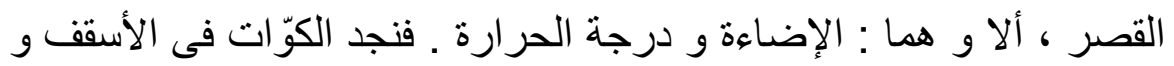

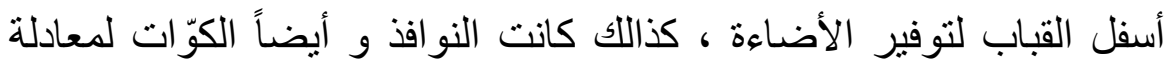
درجات الحرارة داخل أروقة و حجرات القصر صيفاً و شتاءً . 


\section{المبحث الثالث :}

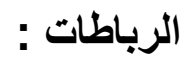

يُعرّف الثيخ الرازى المعنى اللغوى للرباط : " ( ربطه ) شدّه ... و الموضع (

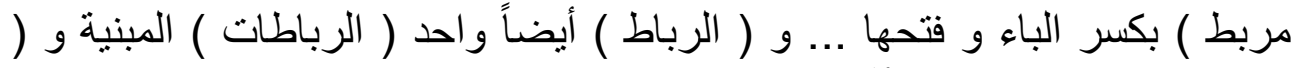

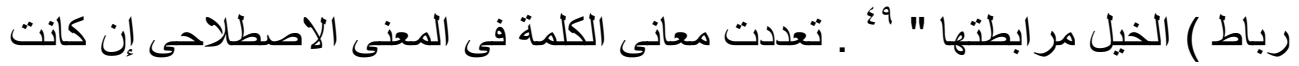

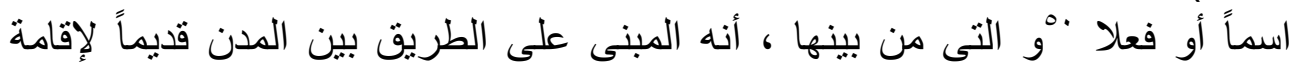

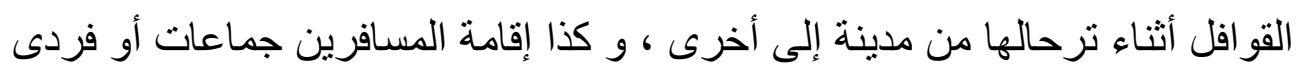

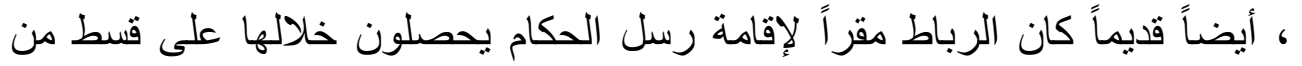

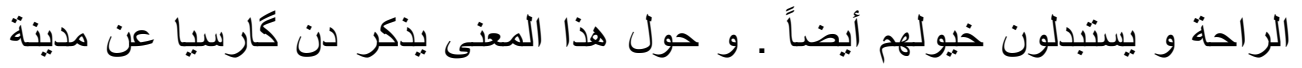

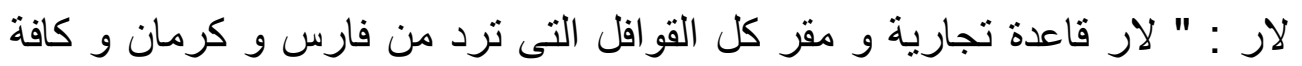

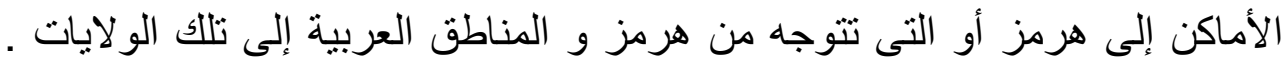

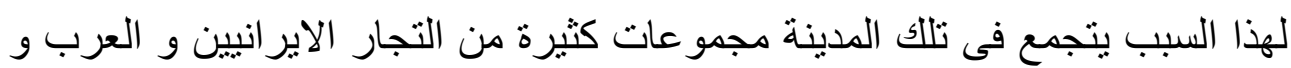
الكفار و اليهود ، و لجذب الأجانب و تجارتهم ، يوجد العديد من الرباطات الكبيرة "

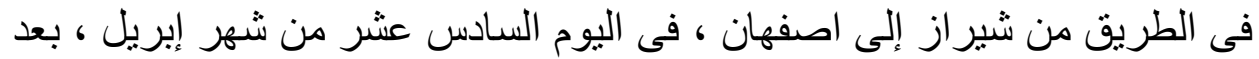

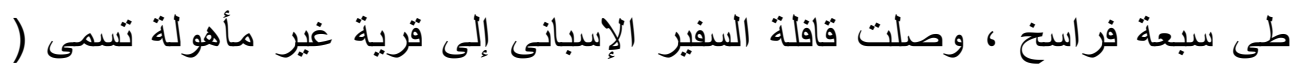
بردنش ) ، و بعد أربعة فراسخ أخرى و صلت القافلة إلى رباط يصفه دن كارسيا

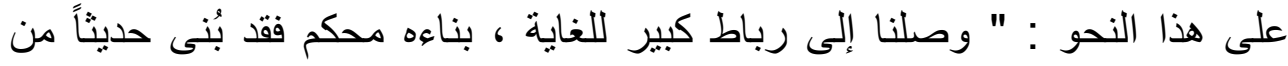

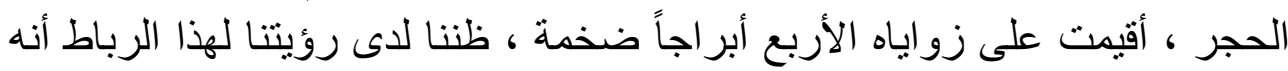

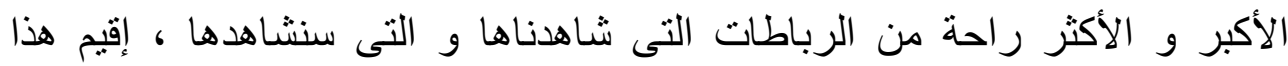

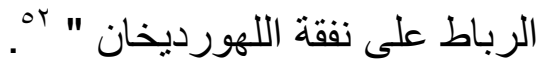

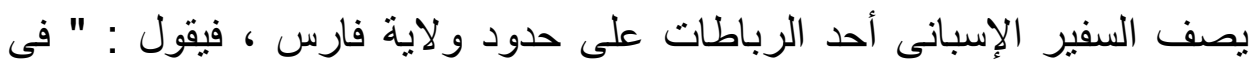

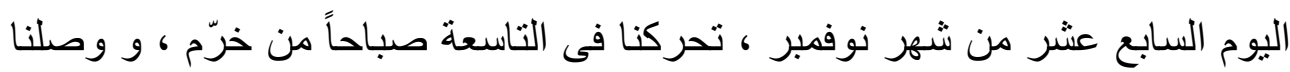
9؛ ـ الرازى : الثنيخ الإمام محمد بن أبى بكر بن عبد القادر ، مختار الصداح ، عنى بترتييه : محمود خاطر ، القاهرة www.almaany.com

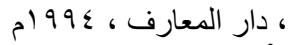

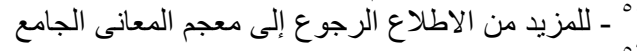

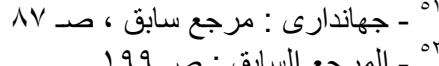

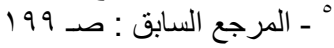


إلى مكان ، على الرغم من كوّنه من حدود فارس لكنه كان مثل لار ، جبلى و دون دون

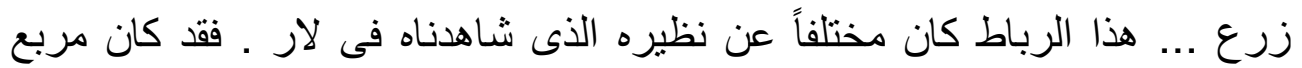

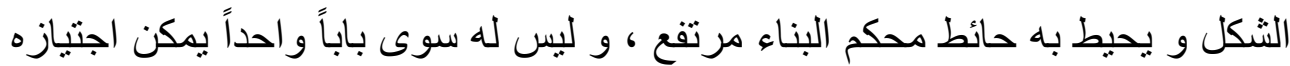

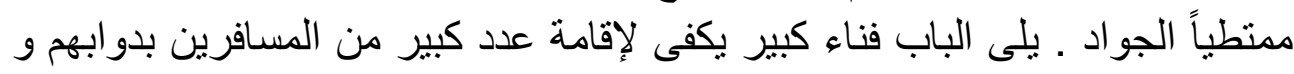

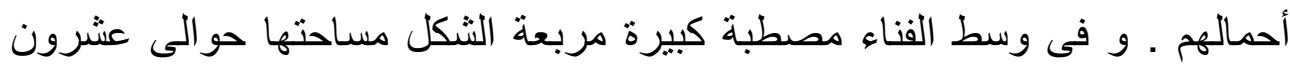

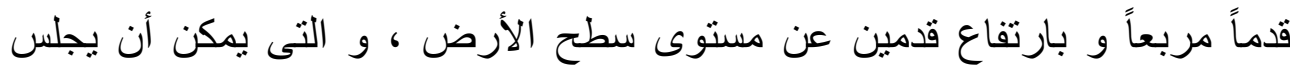

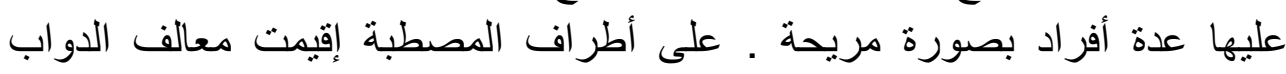

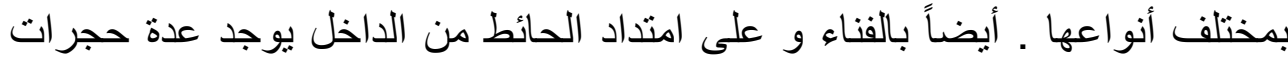

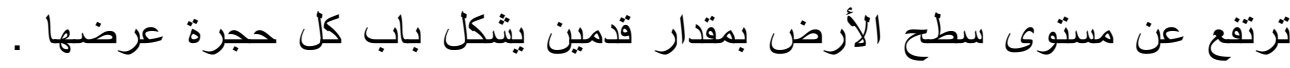

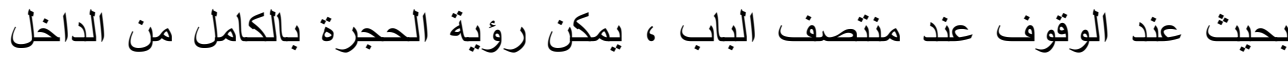

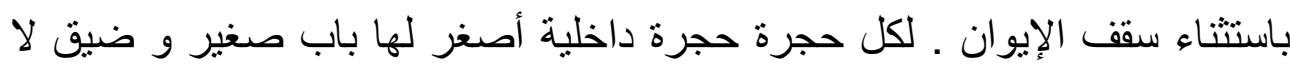

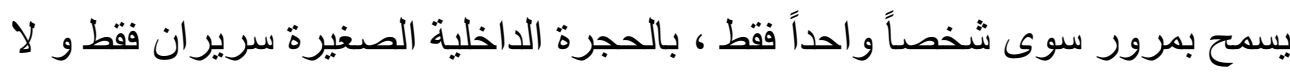

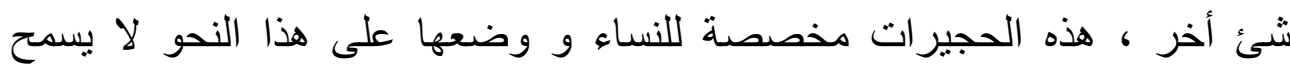

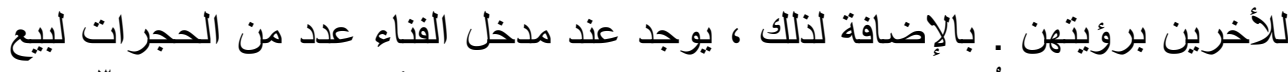

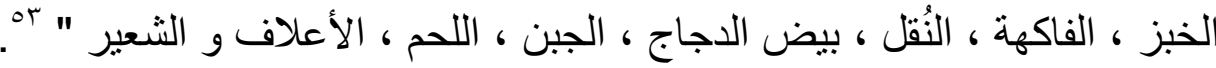

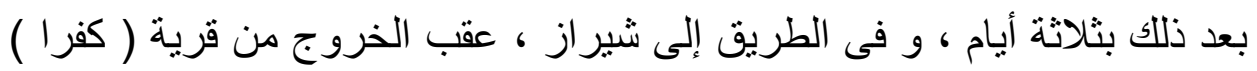

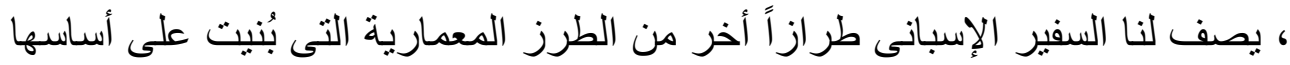

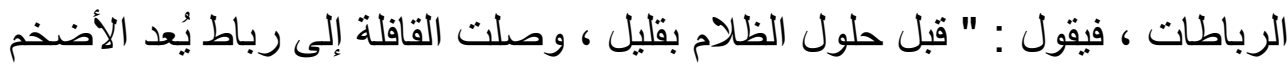

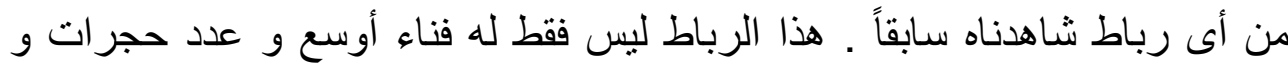

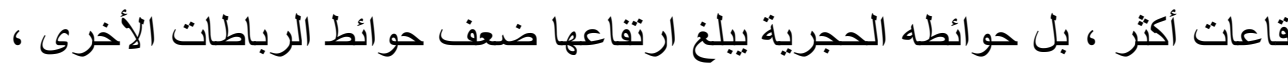

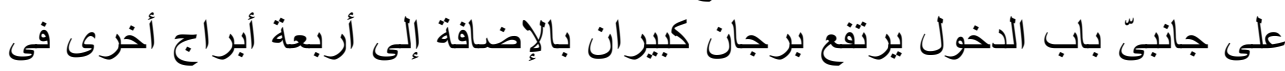

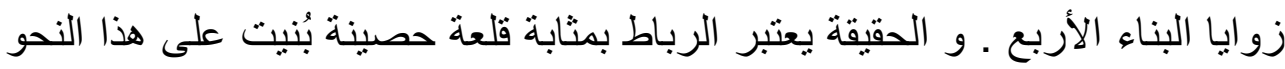

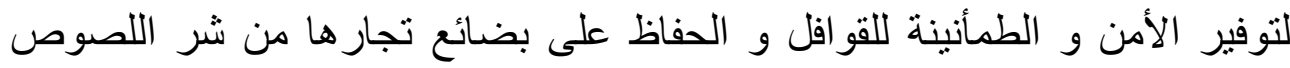

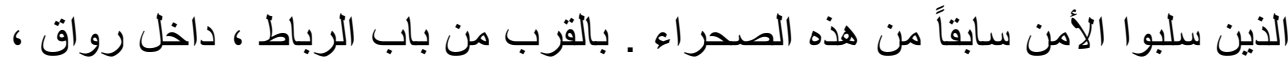

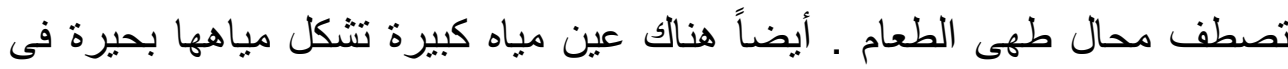

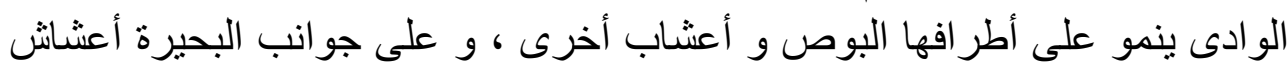


الطيور المائية - البط و الأوز - و طيور أخرى مثل ( سار ) ط طائر برونزى

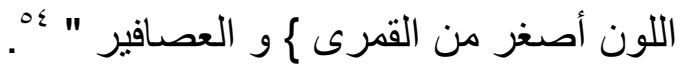

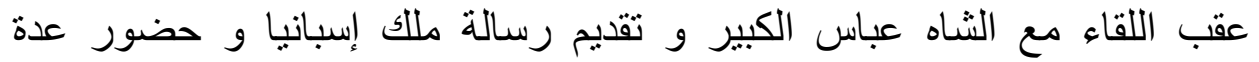

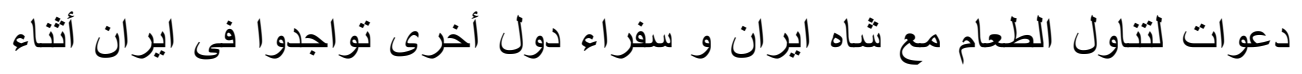

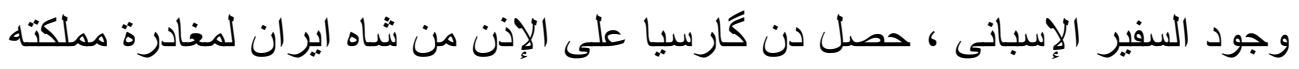

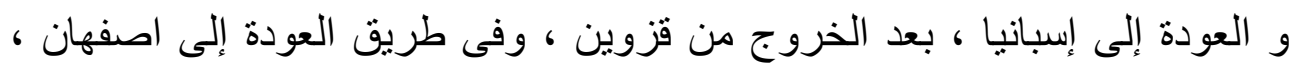

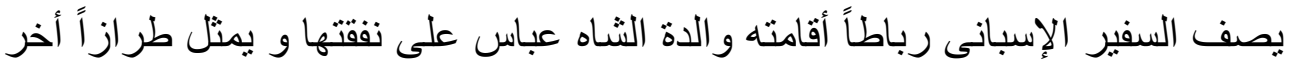

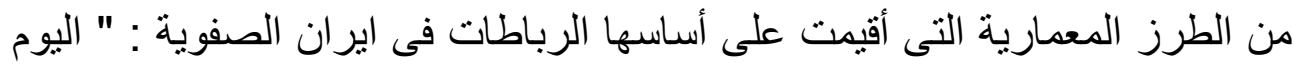

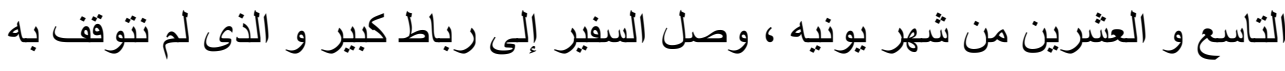

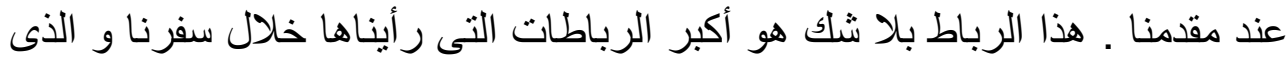

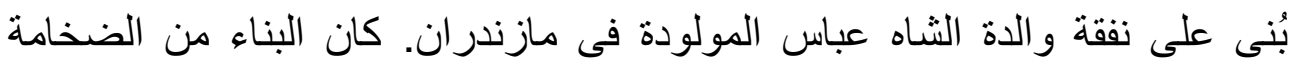

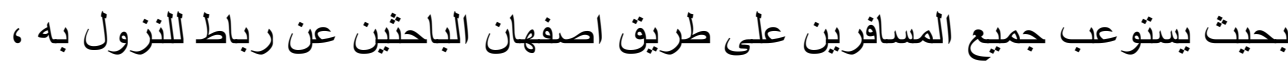
بل يمكن القول إن سعة هذا الرباط تقارب الألف فرد بدو ابهم " 0.

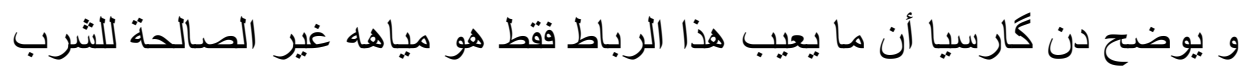

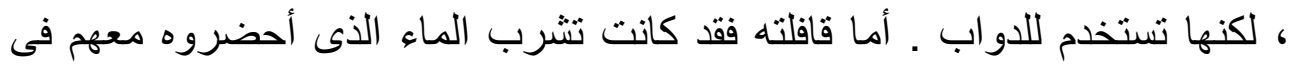

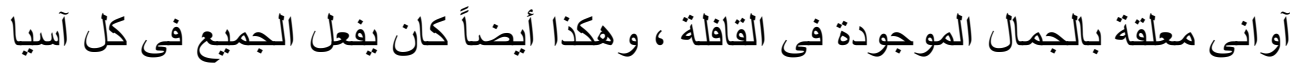

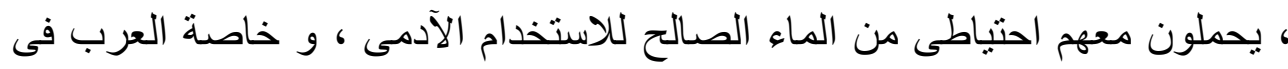

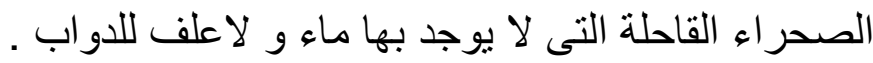

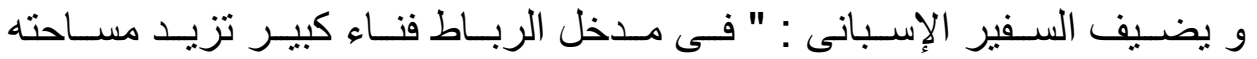

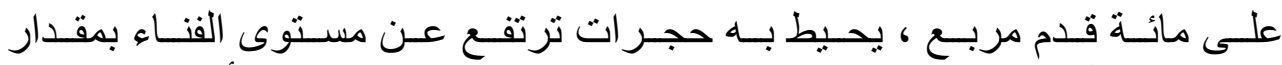

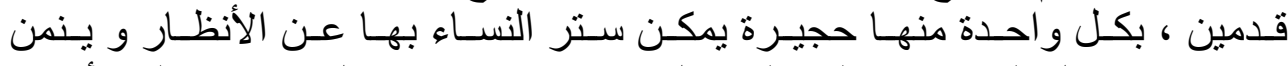

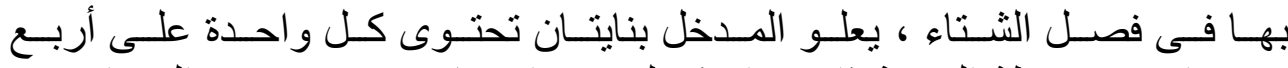

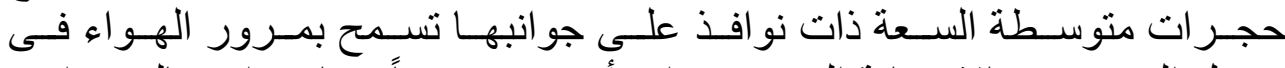

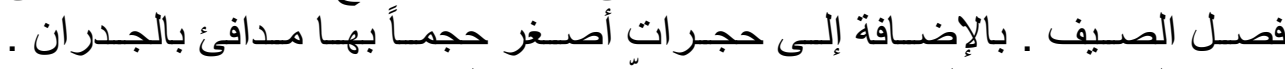

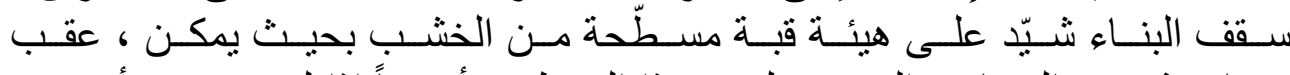

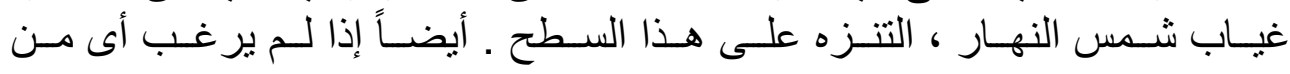




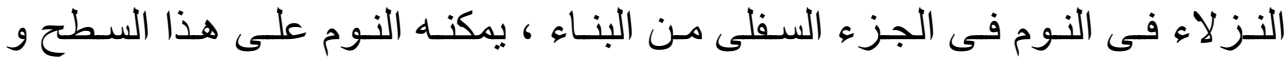

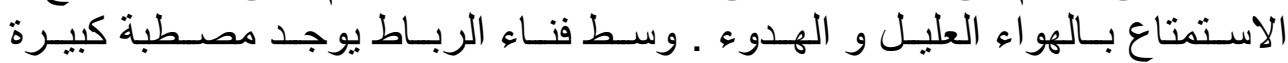

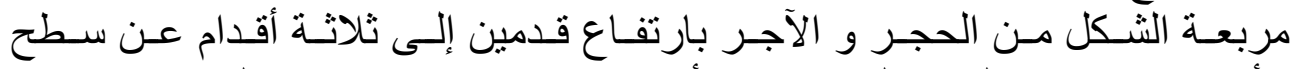

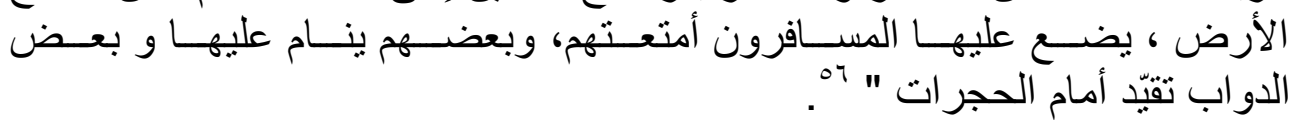

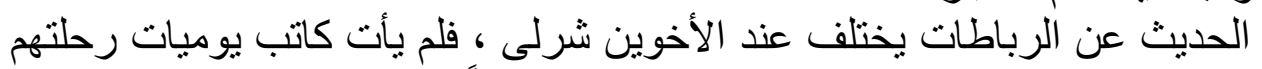

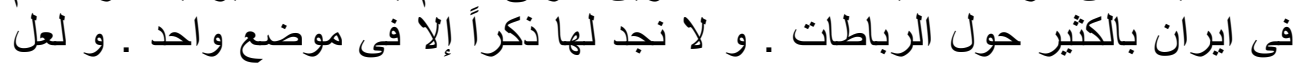

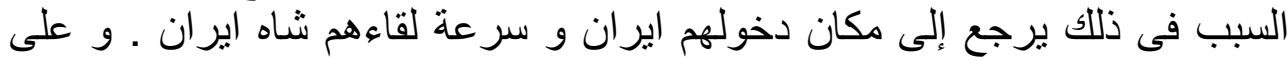

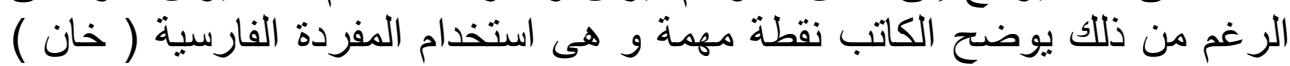

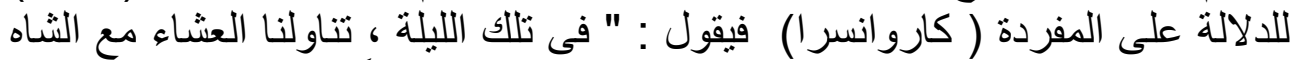

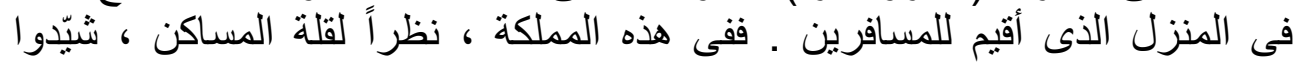

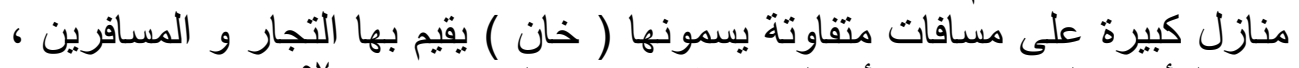

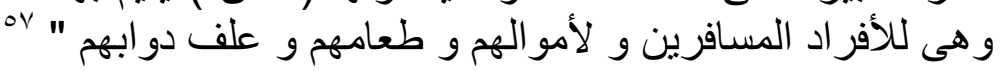

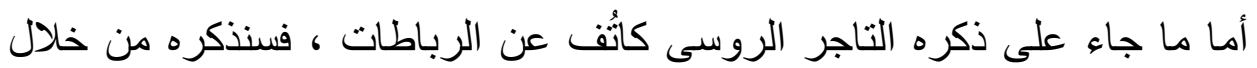

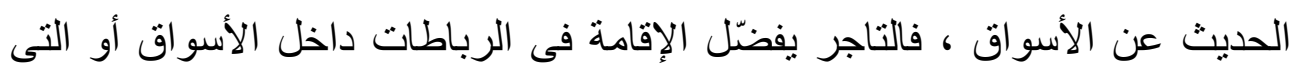

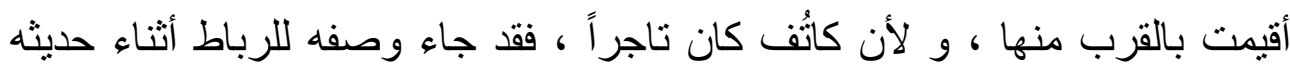

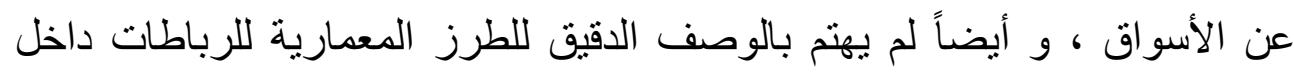

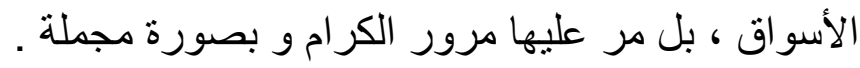

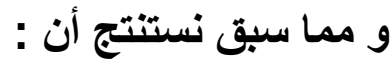

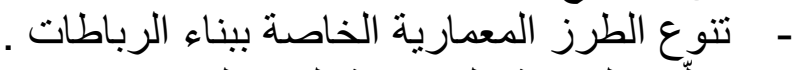

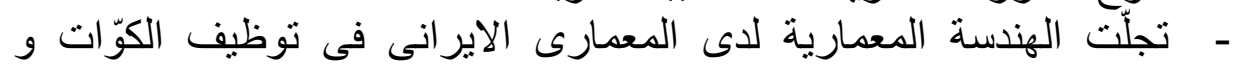

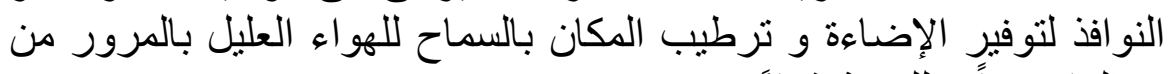

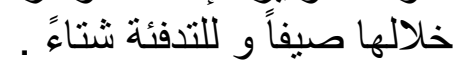

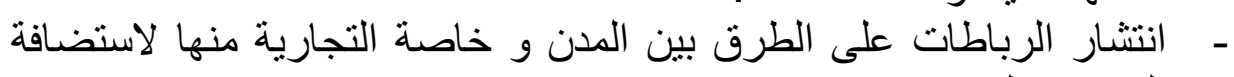

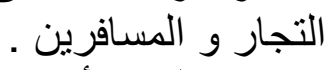
- مرور الزمن أصبحت الرباطات قلعة محصّنة لحماية التجار و تجارتهم و

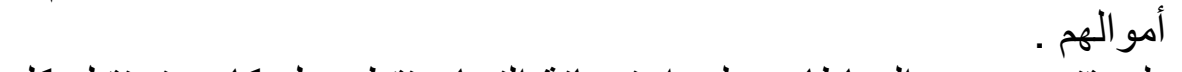
- لم يقتصر دور الرباطات على استضافة التجار فقط ، بل كانت تستقبل كل

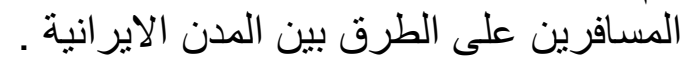


- استخدام المفردة الفارسية ( خان ) للالالة على المفردة اللغوية ( كارو انسر ا )

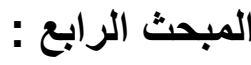

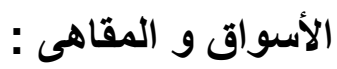

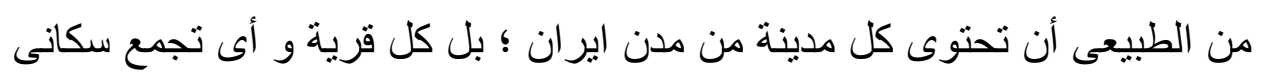

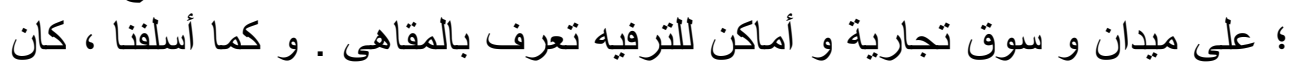

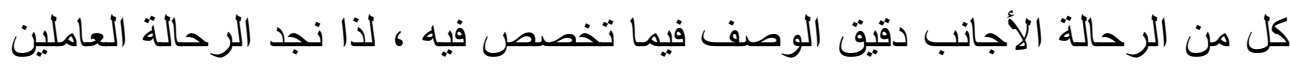

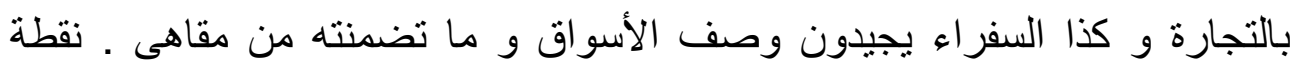

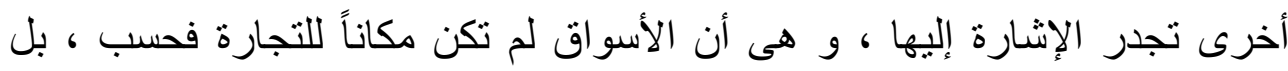

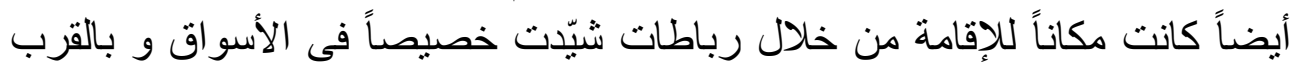

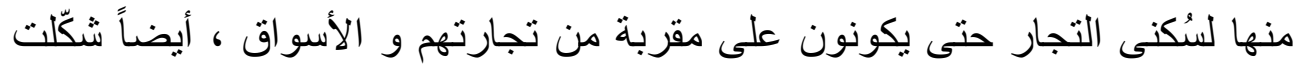

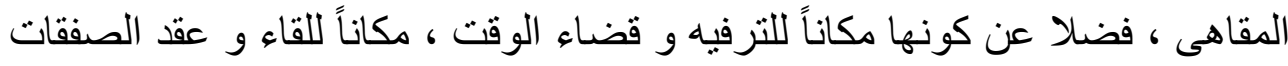

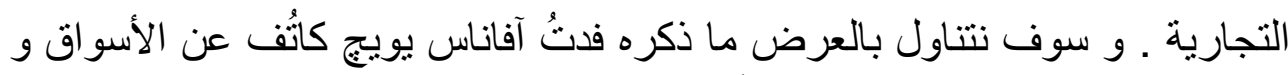

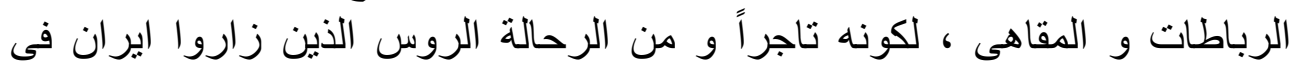

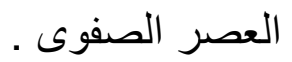

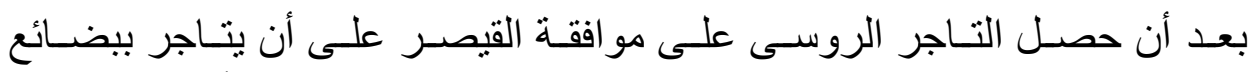

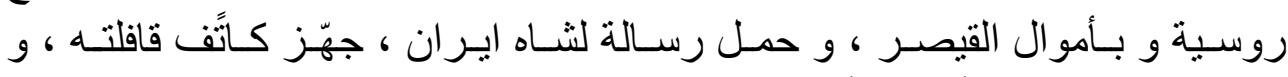

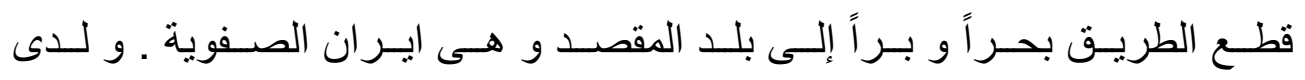

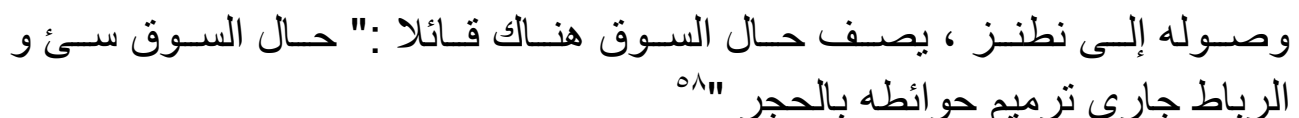

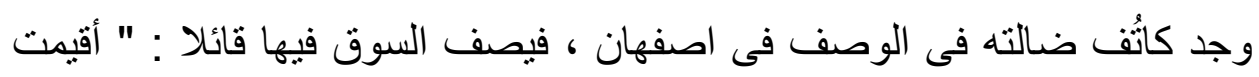

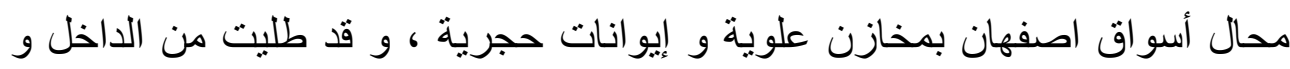

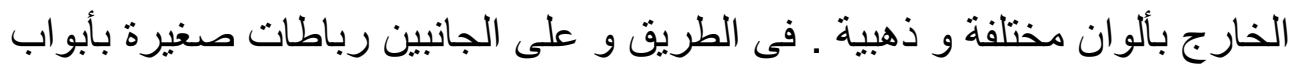

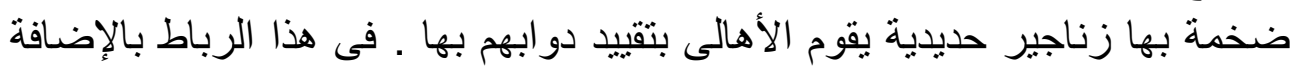
هo - اشر اقى : مصدر سابق ، صـ .0 


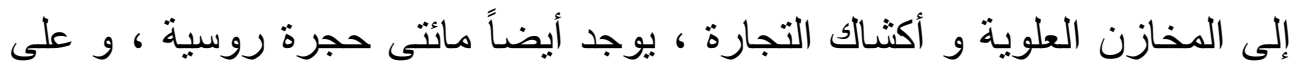

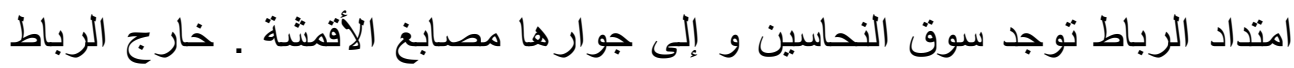

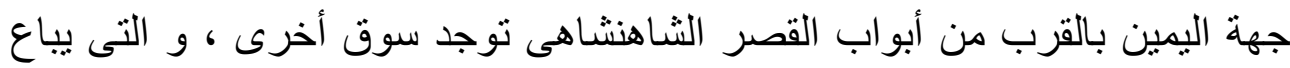

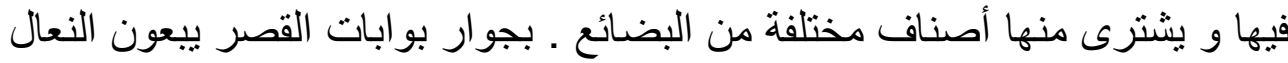

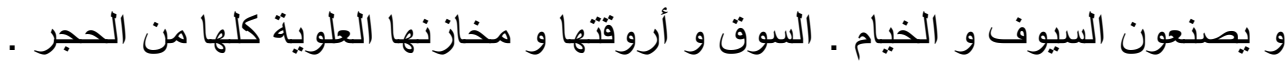

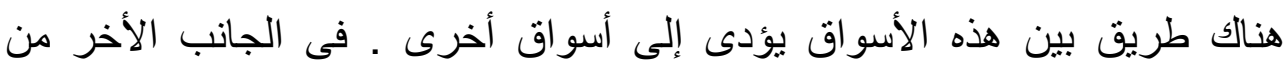

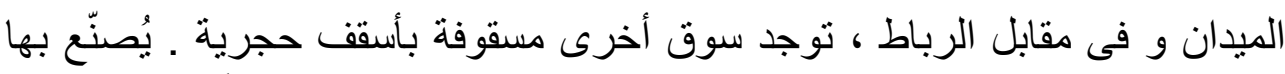

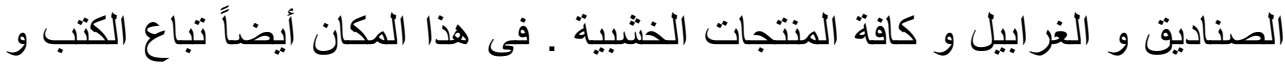

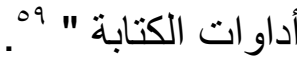

لم يقتصر حديث التاجر الروسى على الأسواق الكبرى ، بل تعداها إلى وصف إنى إنى

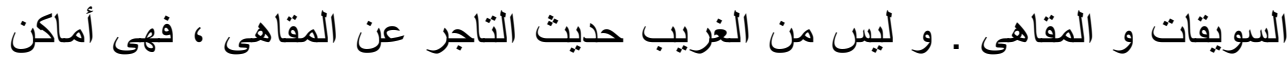

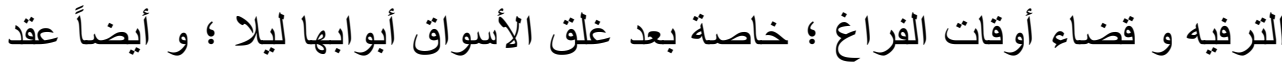

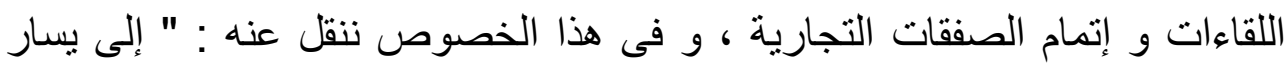

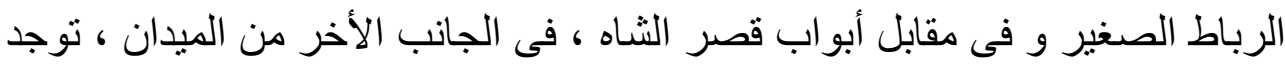

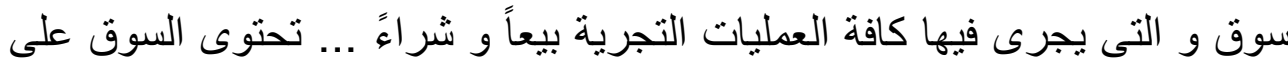

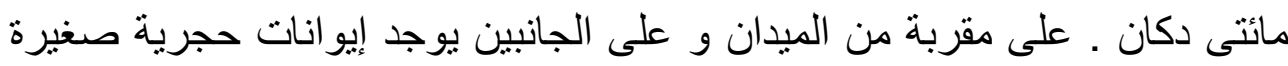

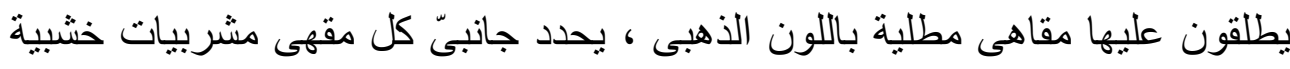

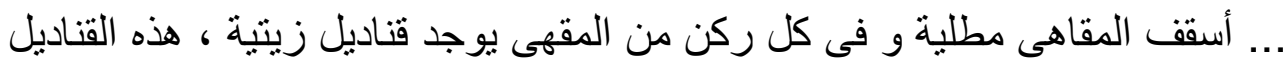

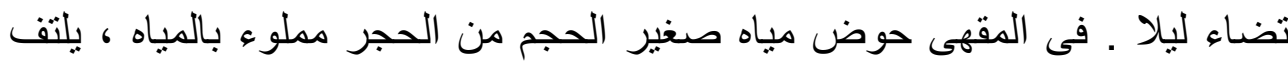

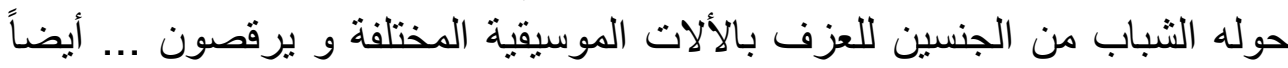

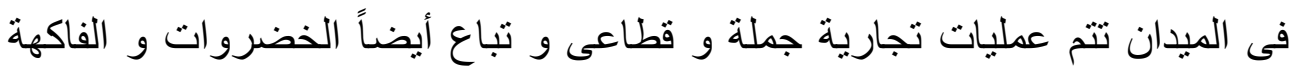

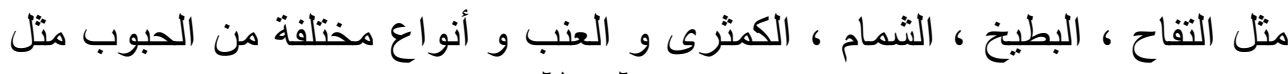

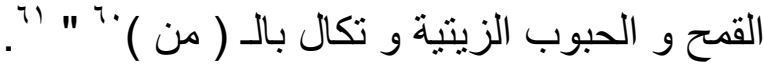

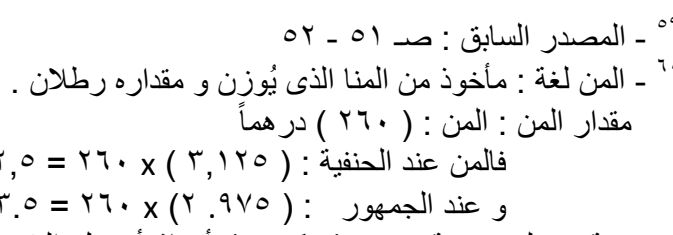

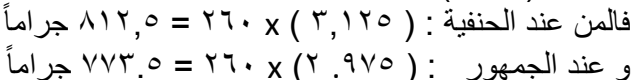

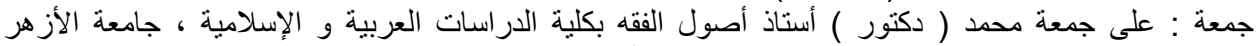

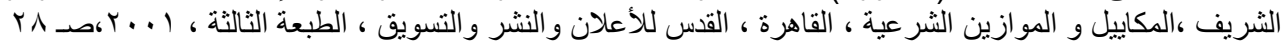




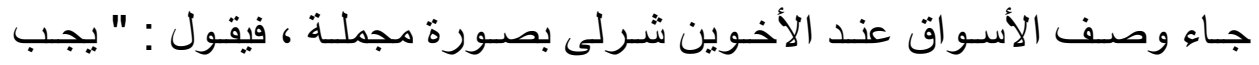

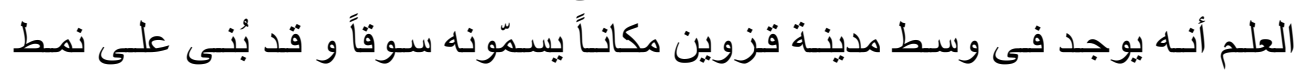

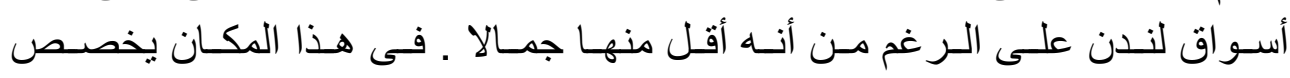

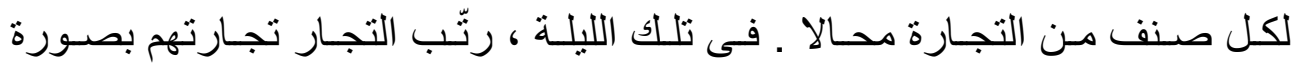

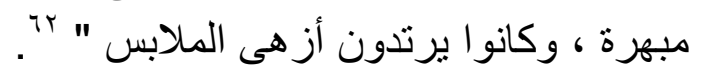

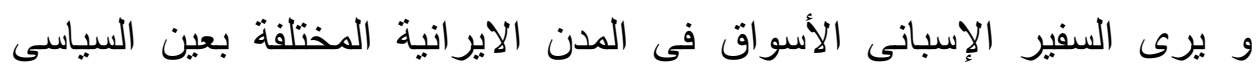

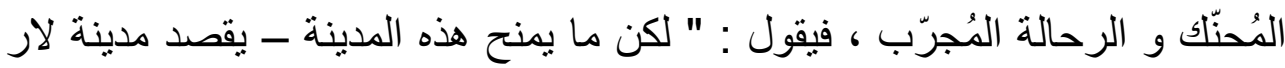

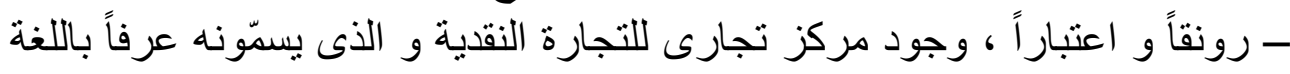

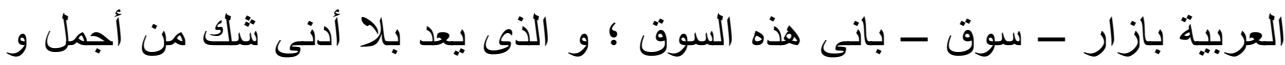

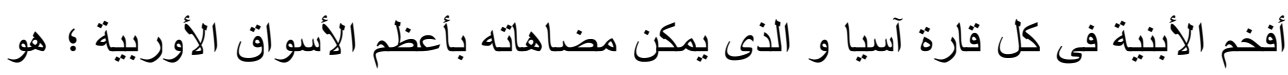

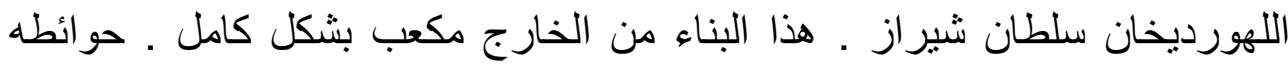

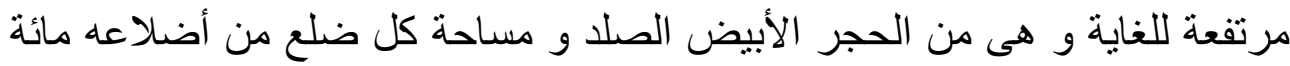

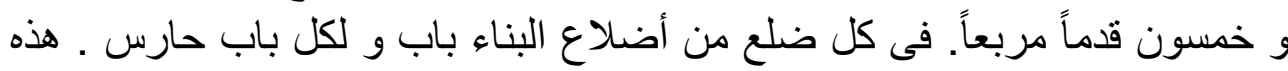

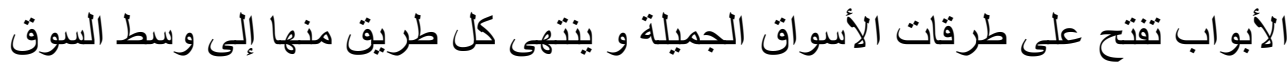

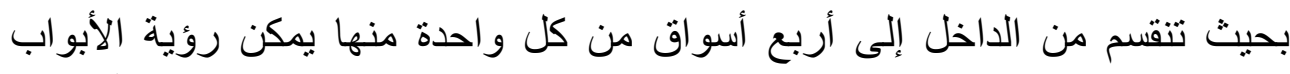

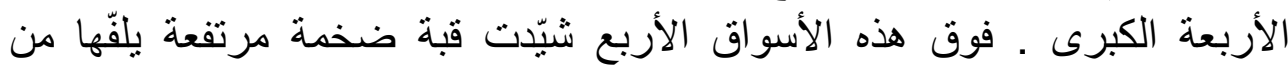

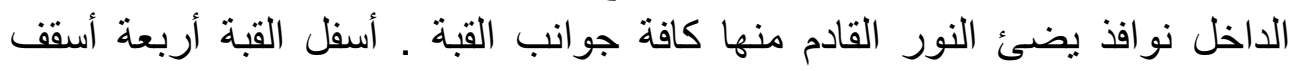

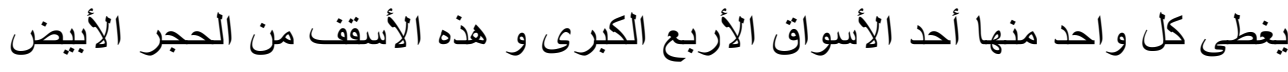

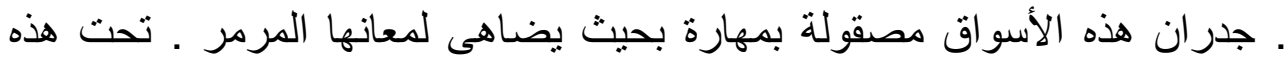

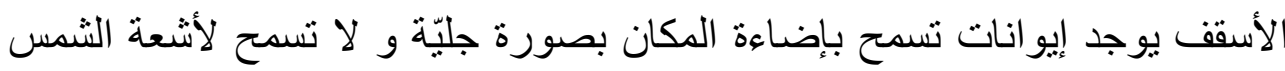

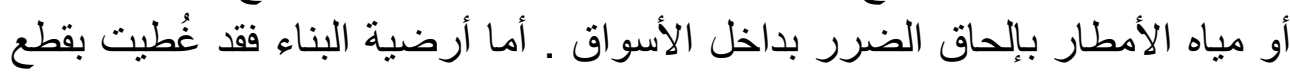

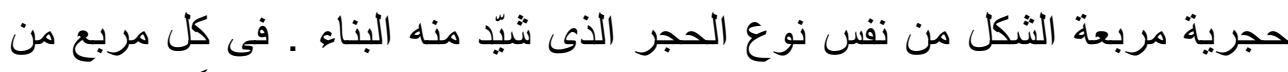

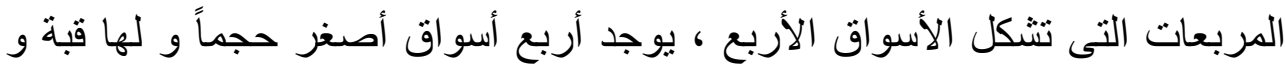

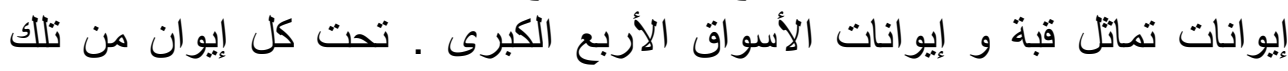

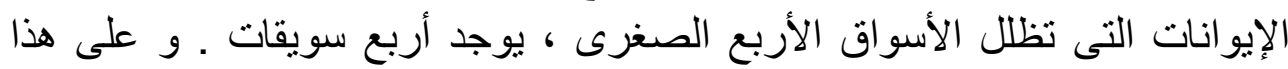

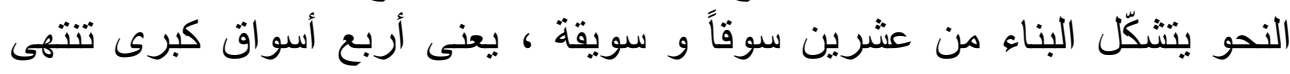


بالأبو اب الأربعة و ست عشر سوقاً صغيرة مرتبطة بالأسو اق الكبرى ـ يباع بالمحال

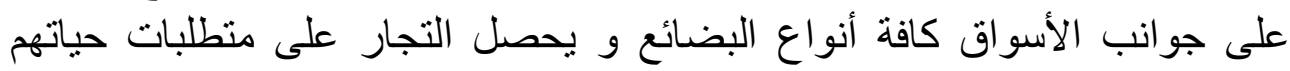

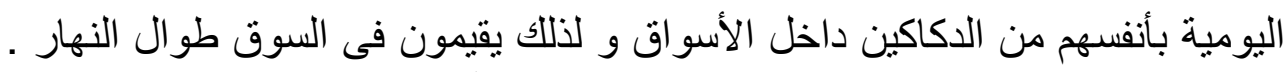

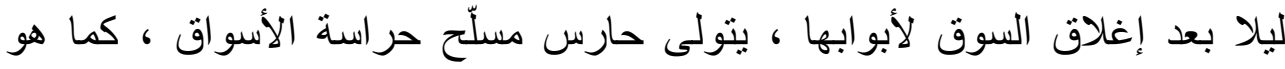

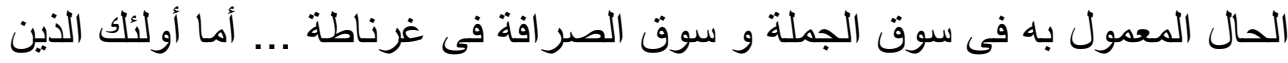

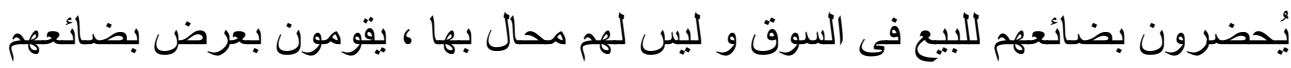

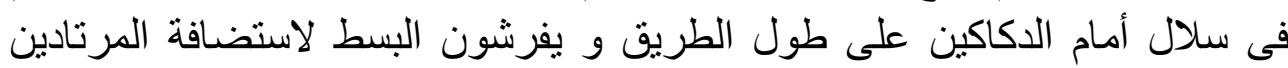

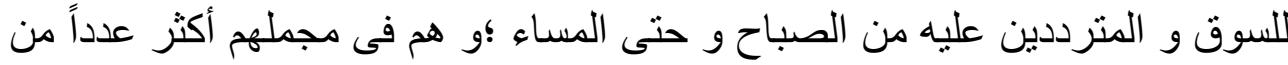

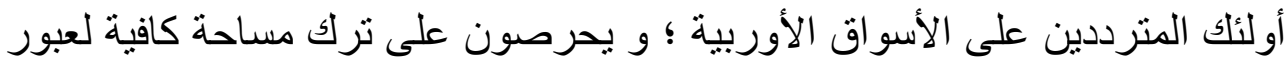

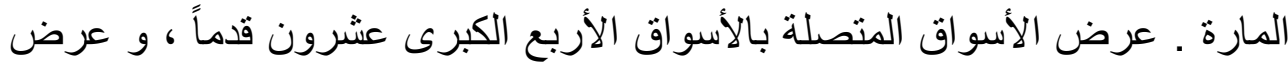

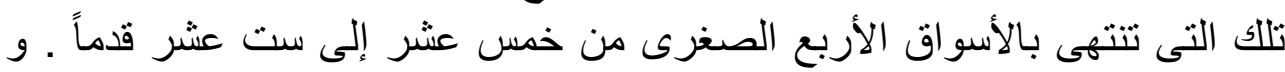

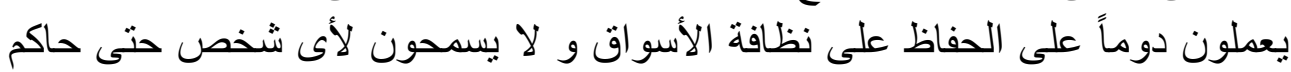
المدينة بالولوج إلى الأسواق ممنطياً دابته " "آ".

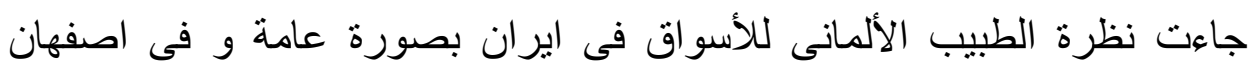

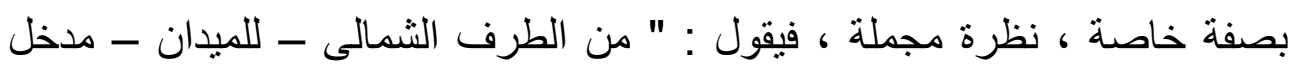

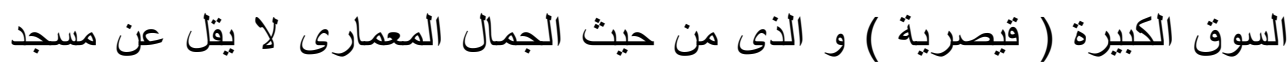

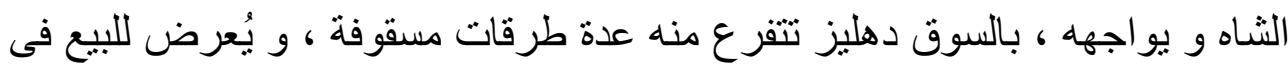

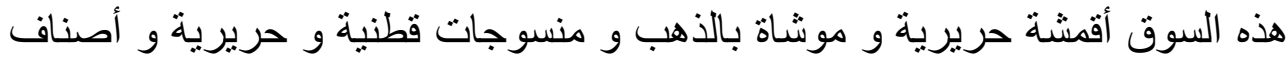
أجنبية أخرى ... و فى مدن ايران الأخرى بطلقون على السئ السوق الكبيرة اسم "

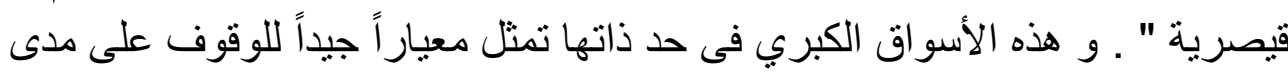

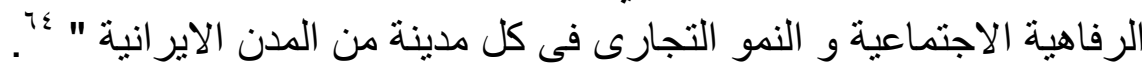

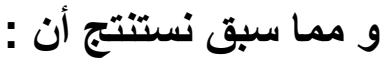

- حتى فى الأسواق ، لم يغفل المعمارى الاير انى فى الهندسة الإنشائية استخدام

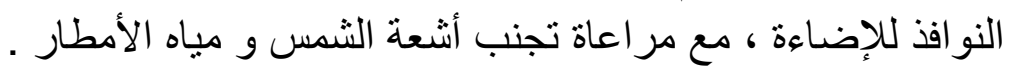




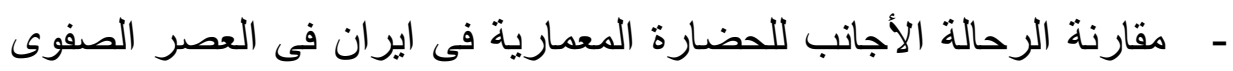

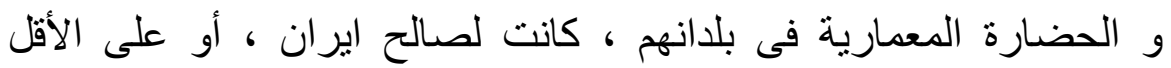

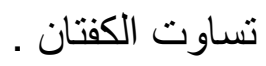
- عكست الأسواق فى هذان العصر مدى الرفاهية الاجتماعية و النمو التهان

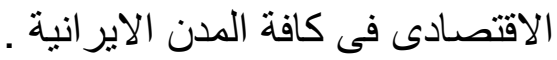

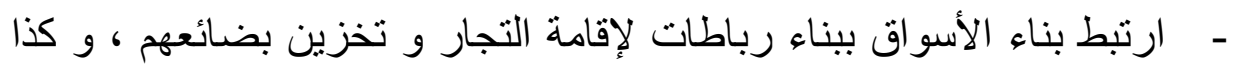

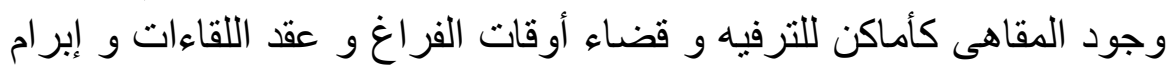

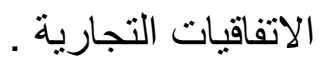
المبحث الخامس : (الفاتيات

\section{الجسور و القتاطر : - الم}

الجسور و القناطر من الأنكال المعمارية التى حفلت بها ايران فى العصى التصر

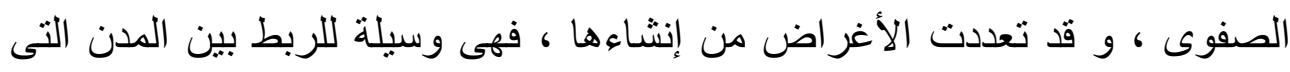

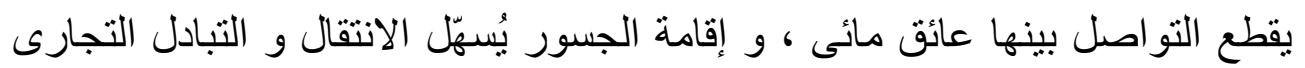

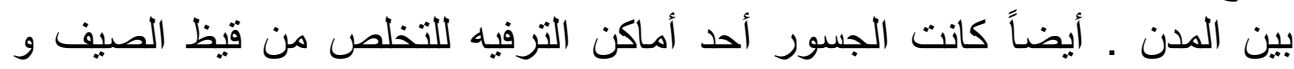

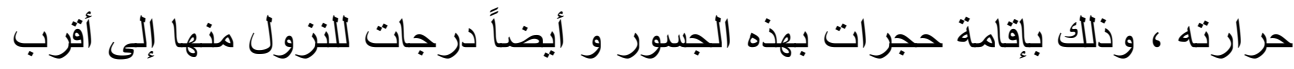

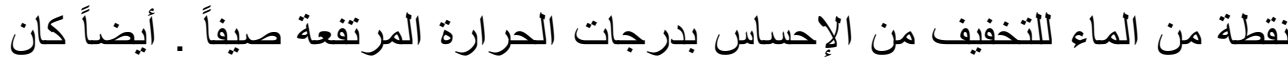

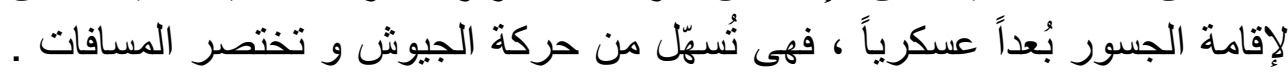

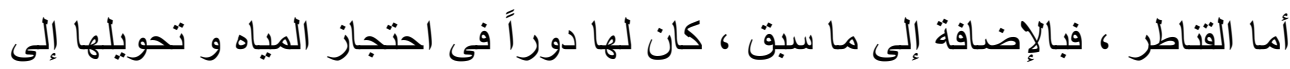

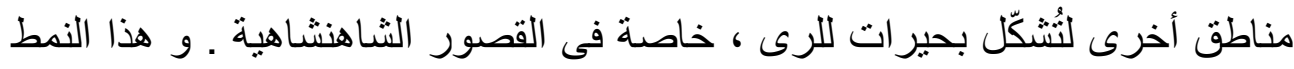

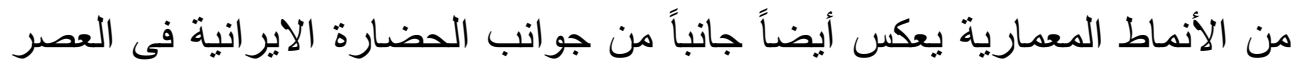

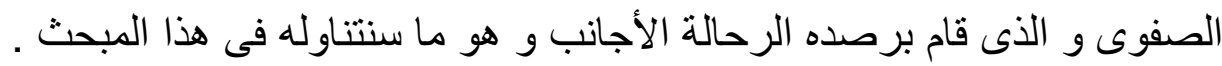

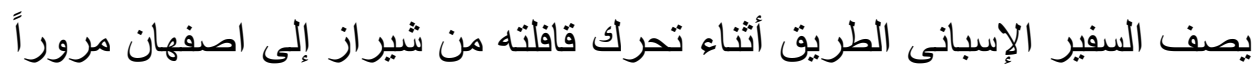

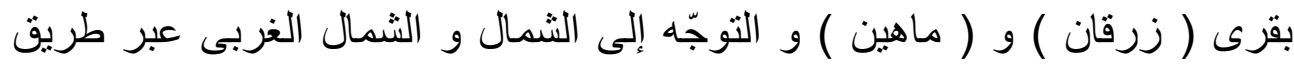

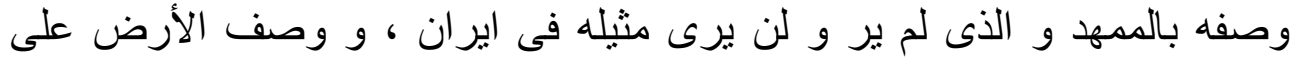

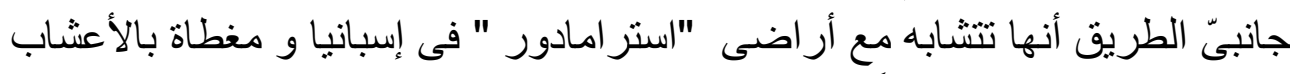

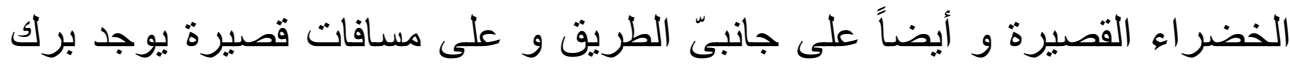

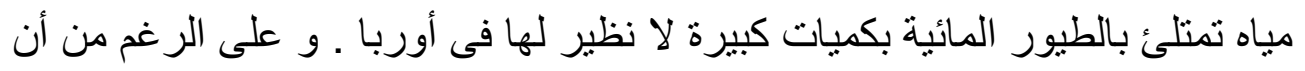


هذه البرك المائية ليست بالعميقة ، إلا أنها يمكن أن تطغى على الطريق و تعيق

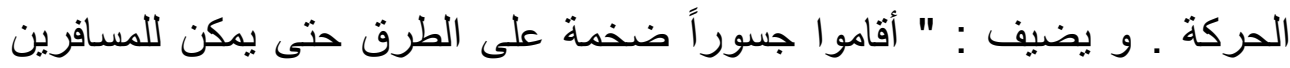

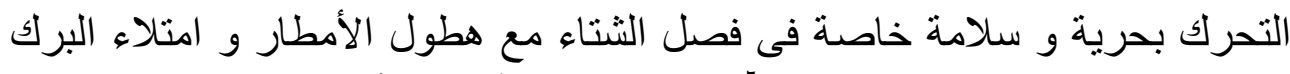

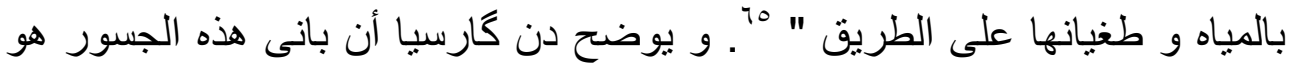

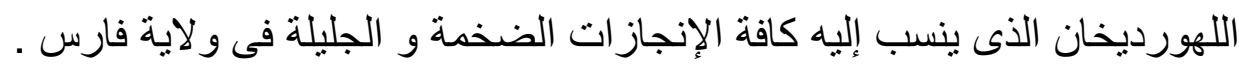

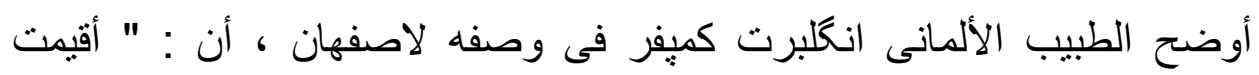

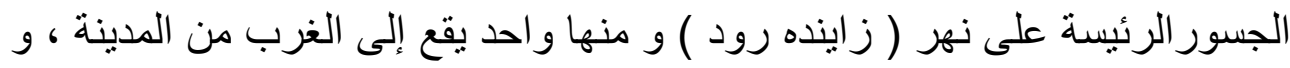

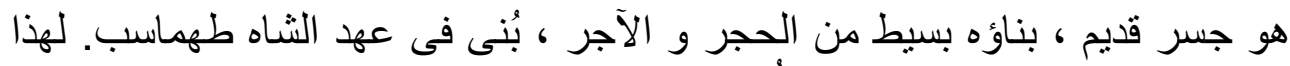

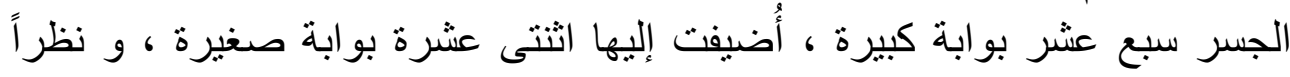

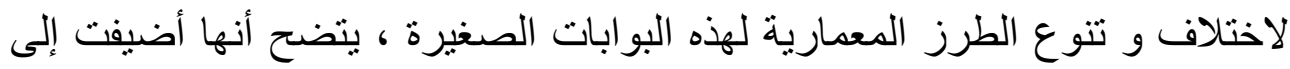

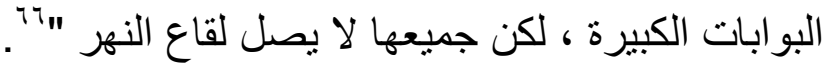

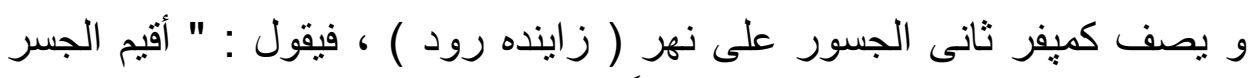

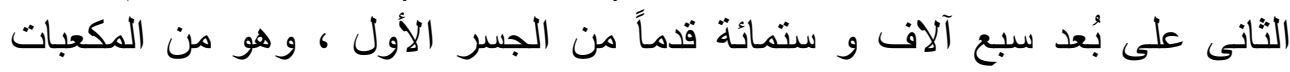

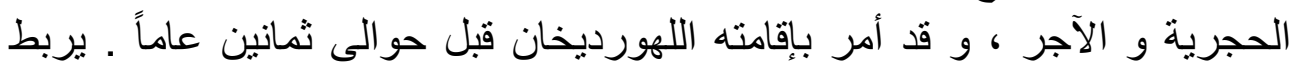

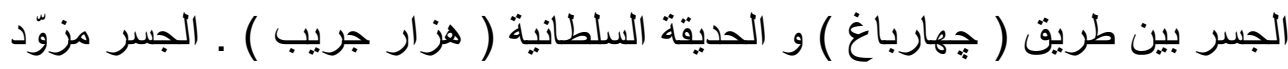

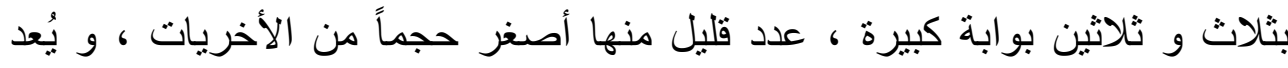

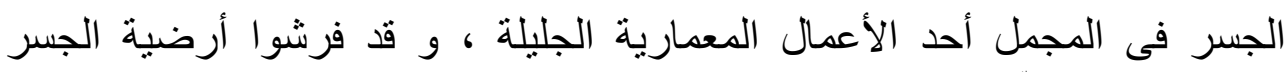

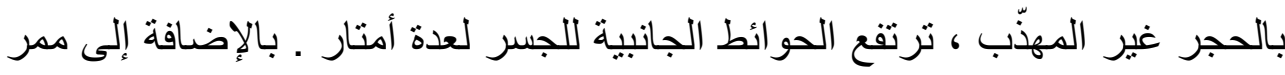

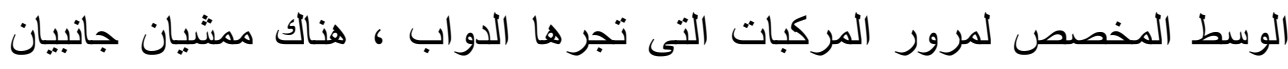

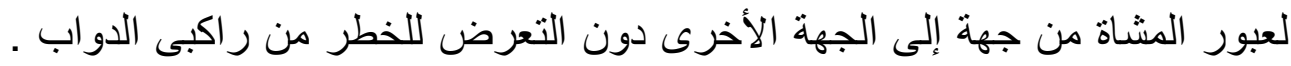

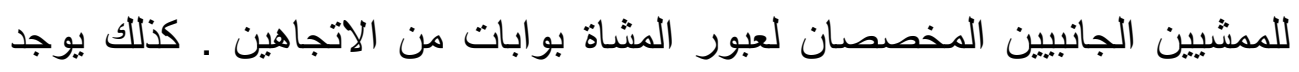

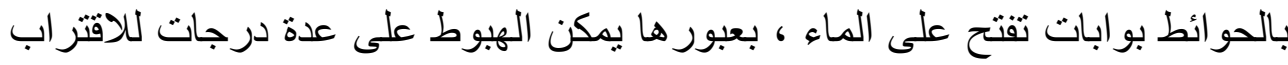

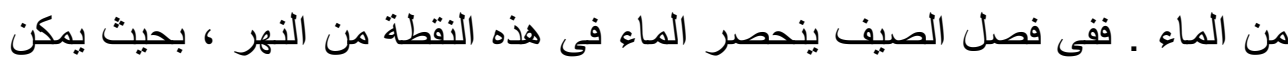

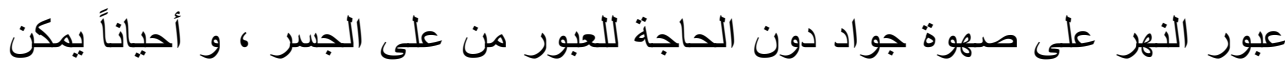

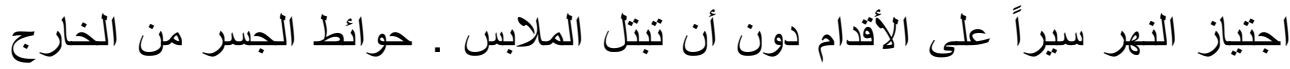

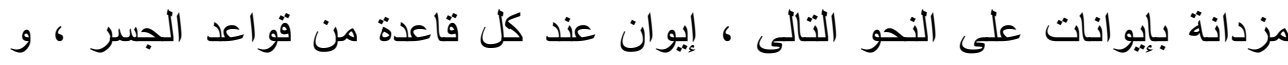




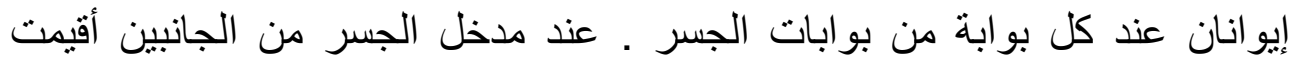

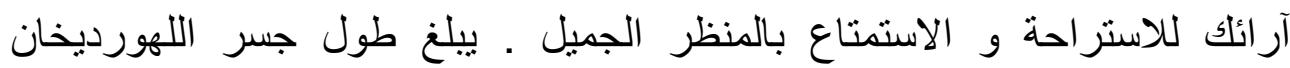

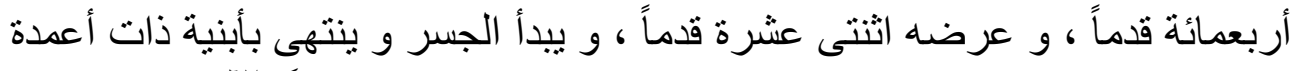

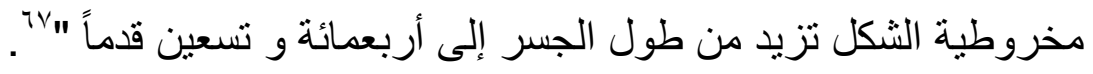

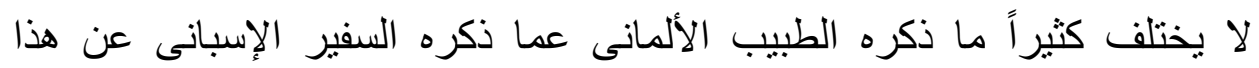

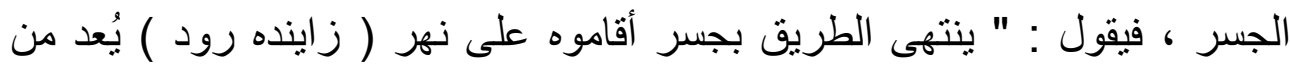

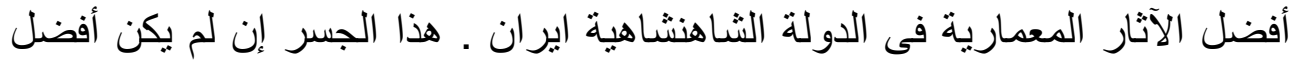

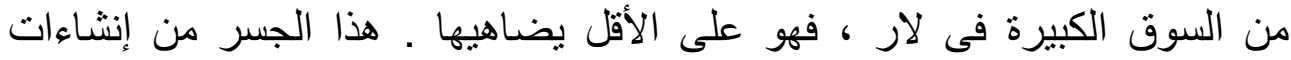

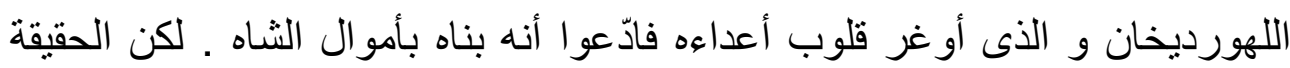

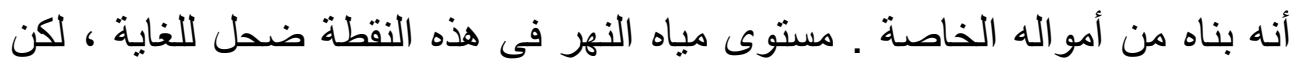

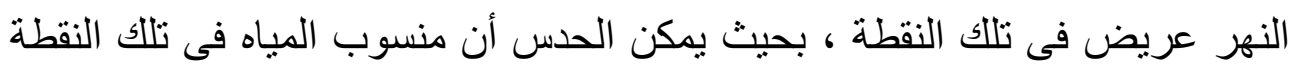

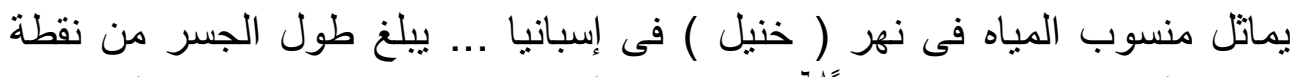

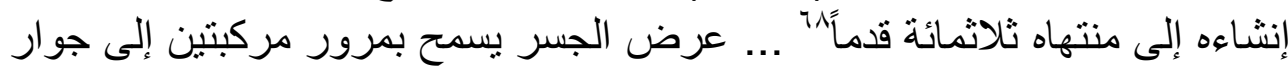

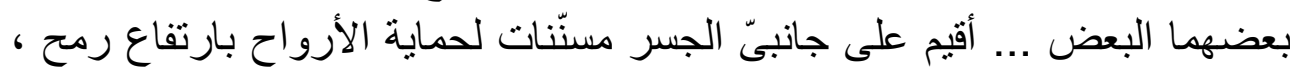

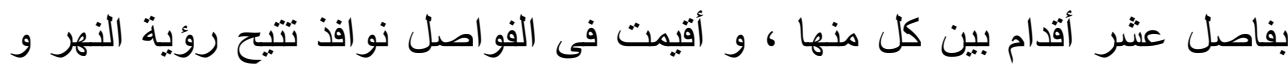

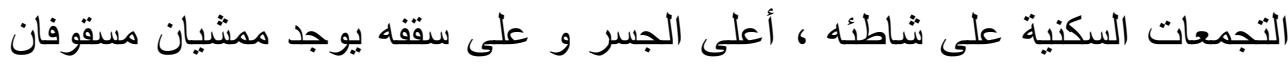

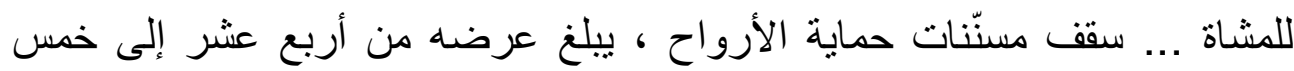

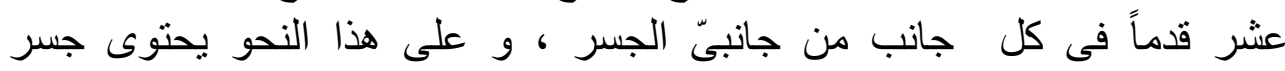

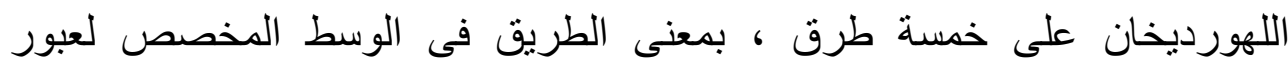

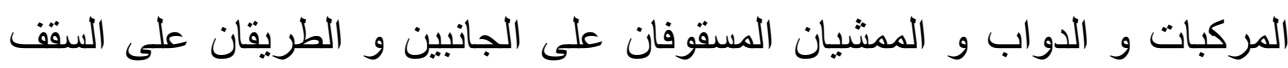

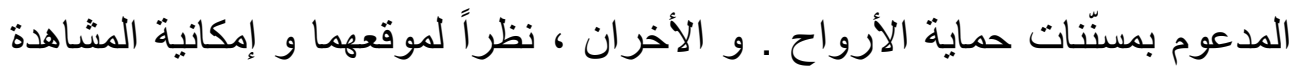
من خلالهما ، هما الأكثر استخداماً لو الارواح.

يصف انكلبرت كميفر فى يوميات السفر إلى ايران جسر اً ثالثاً على نهر ( زاينده

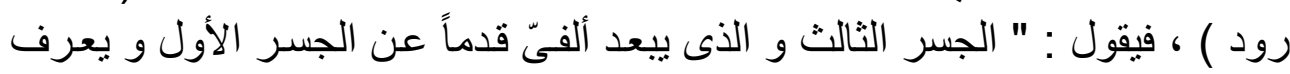




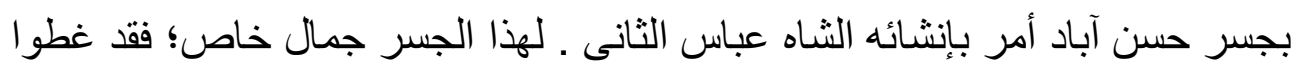

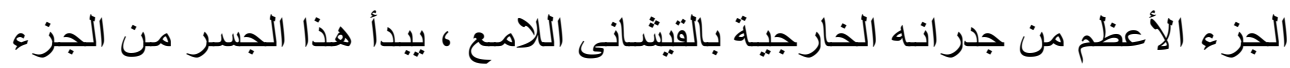

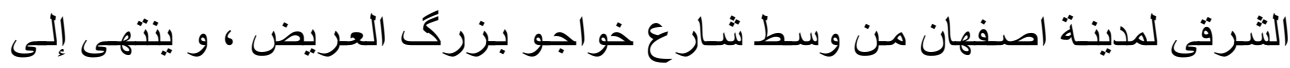

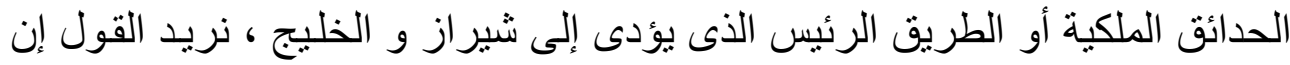

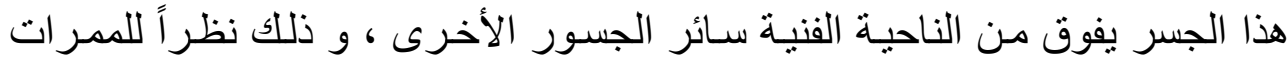

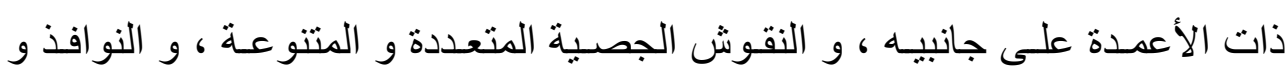

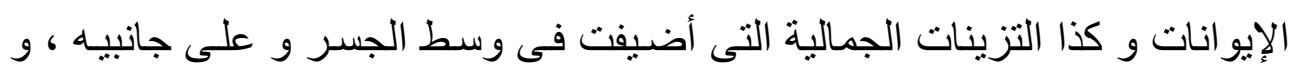

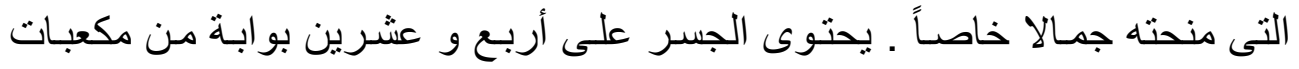

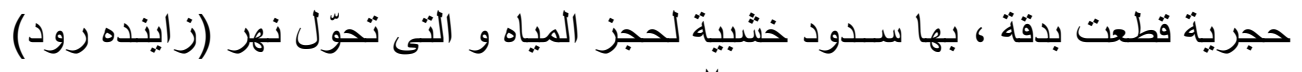

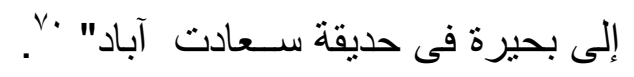

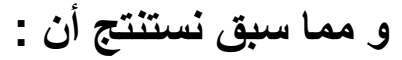

- ـشكّت البيئة الطبيعية أحد أهم العوامل للإبداع المعمارى فى ايران فى

العصر الصفوى ، فكانت الجسور لربط المدن ببعضها البعض لتيسير التبادل التجارى ، و الترفيه عن الثعب فى فصل الصيف ، كما كان لها دوراً من الناحية العسكرية و الزراعية ، لكن هذا الدور يخرج عن موضوع الدراسة . - الأبعاد التى أوردها الرحالة الأجانب من طول و عرض المبانى و الجسور التى قامو ا بوصفها ، هى أبعاد تقديرية و ليست فعلية . - تطور فن المعهـار فى عهد الثـاه عبـاس الثانى عمـا كـان عليه فى عهد الثنـاه عبـاس الكبير و فقـاً لمـا يـذكره الطبيب الألمـانى عن الجسـور على

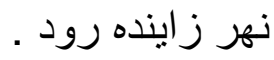




\section{أهم النتائج التى توصلت إليها الدراسة :}

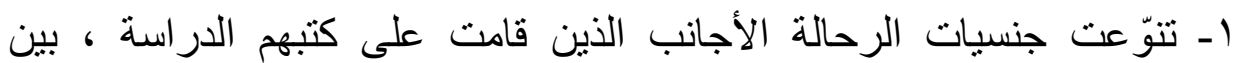

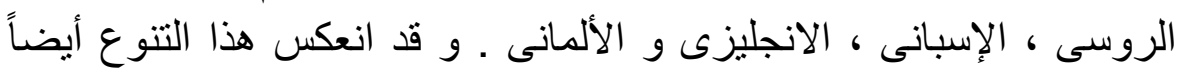

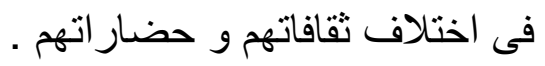

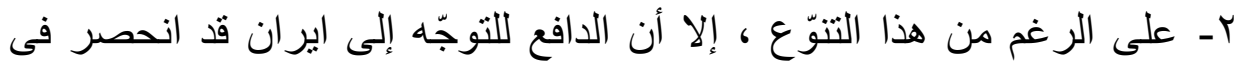

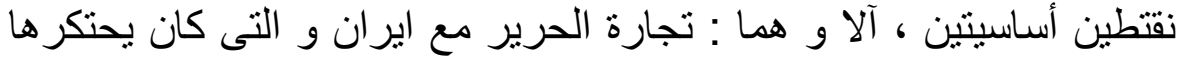
شاه ايران ، و عقد اتفاقيات مع ايران لخلق تحالف ضد الاند الامبراطورية

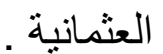

r- لعبت الدذهيّة دوراً هاماً فى اختبار الدول الأوربية لايران الثيعية الدذهب

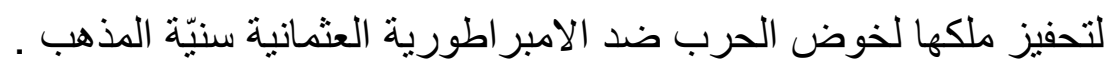

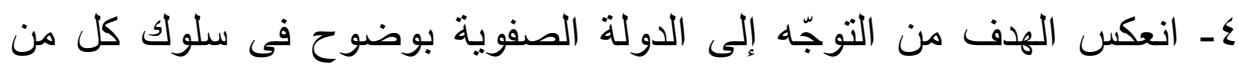

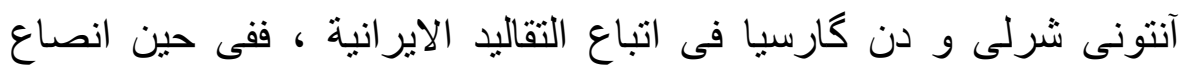

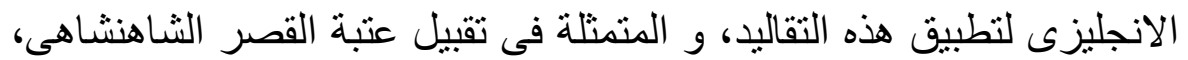

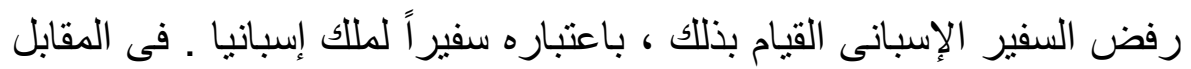

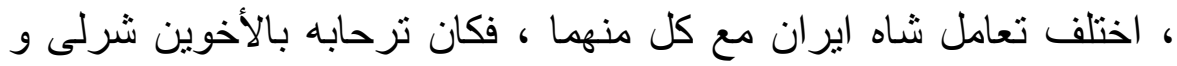

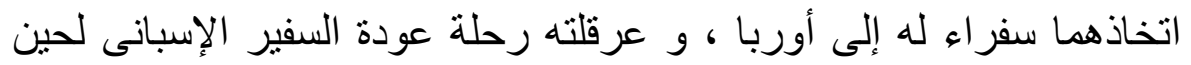

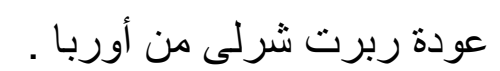
هـ تعدد المناطق التى دخل منها الرحالة إلى ايران أناح لهم فرصة كبان كبيرة للتنقل

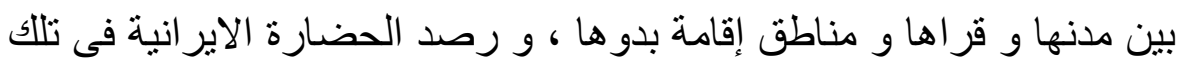

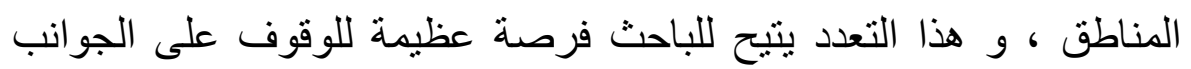

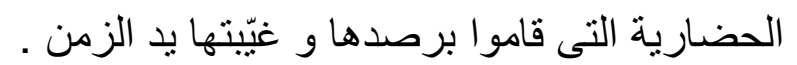




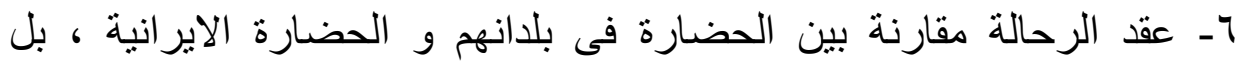

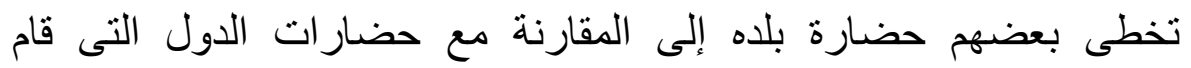

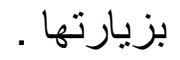

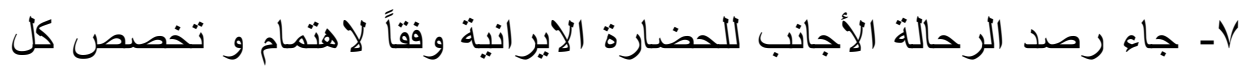

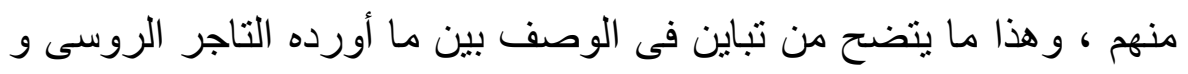

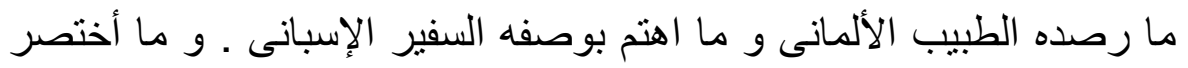
وصفه الانجليزى . مالطين.

^- يتضح مما كتبه الرحالة التفاوت الحضارى فى المدن و خاصة العاصمة عن

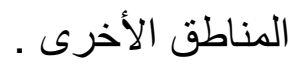

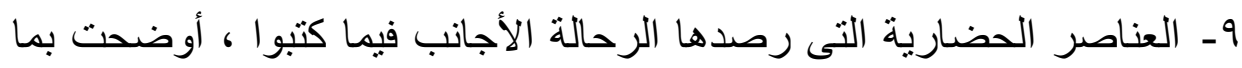

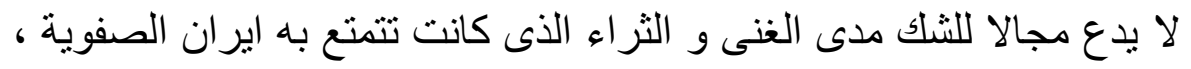

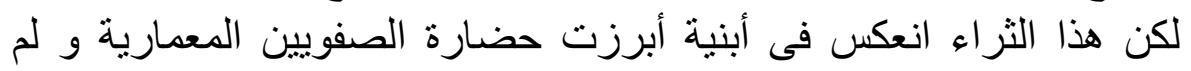

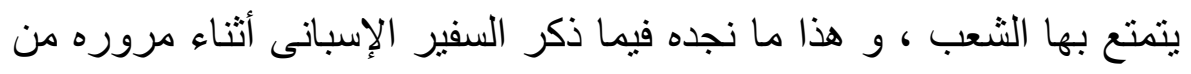

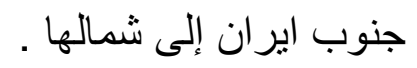

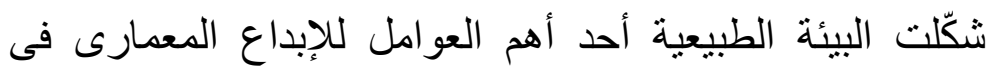

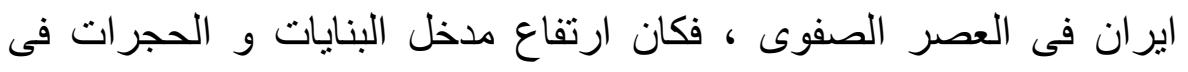

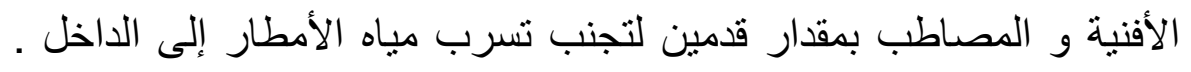

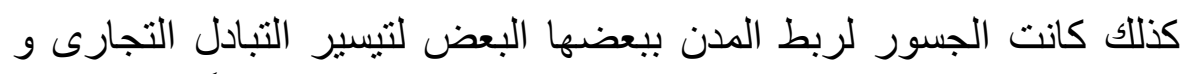

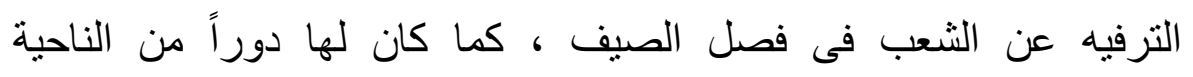

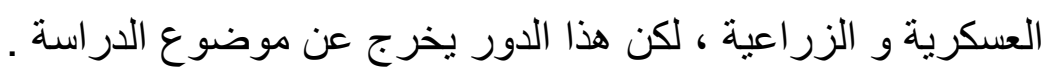

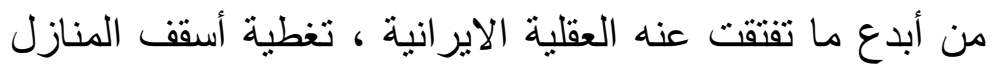

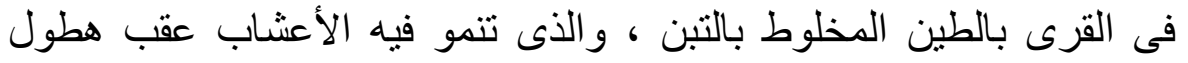

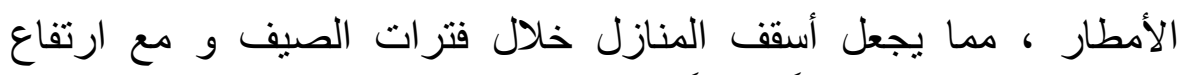

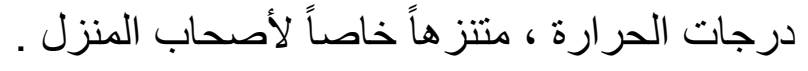

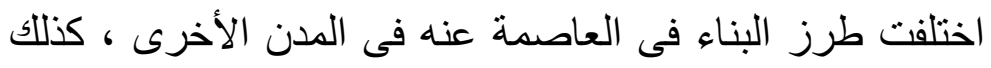

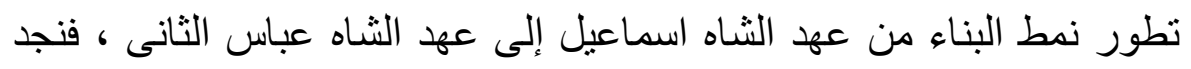

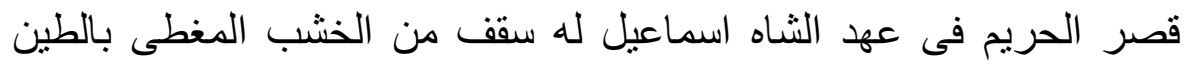

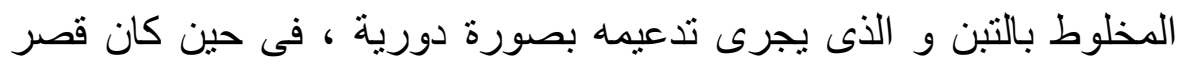

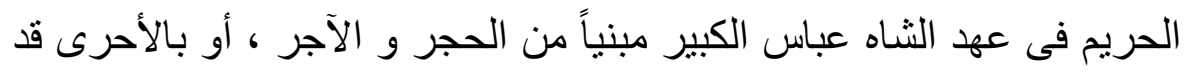




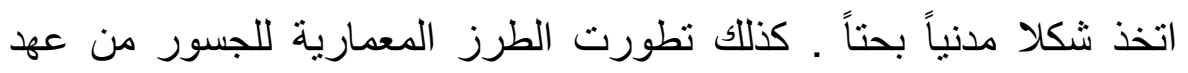

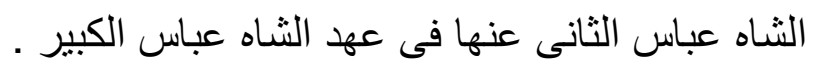

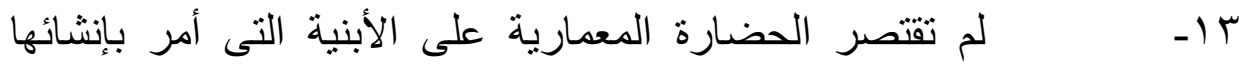

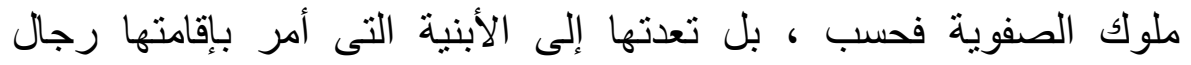

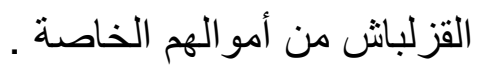

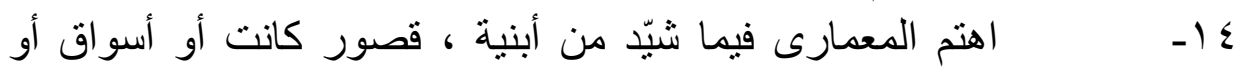

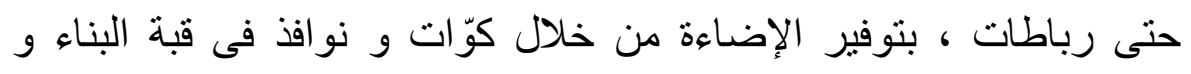

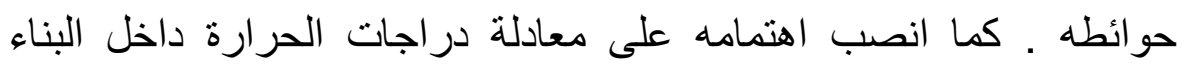

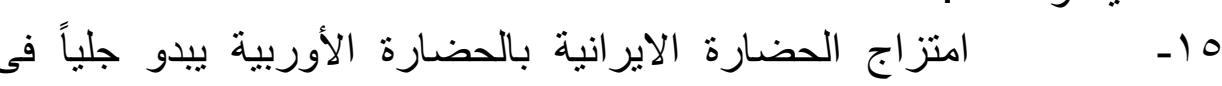

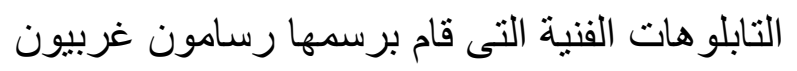

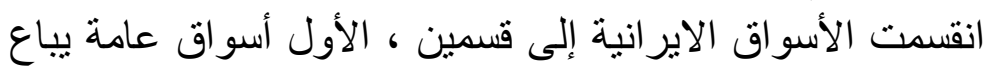

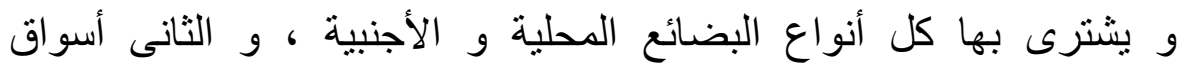

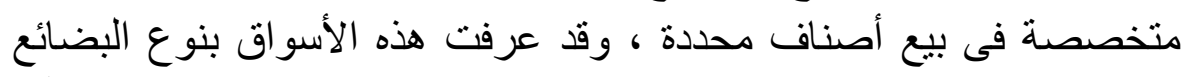

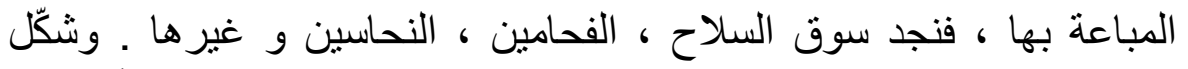

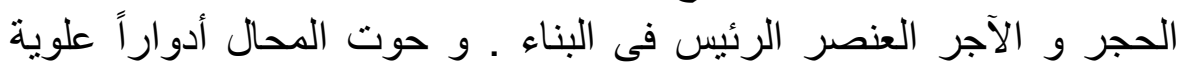

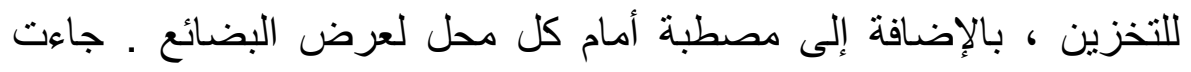

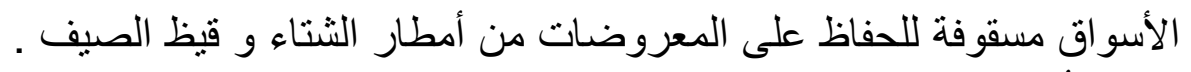

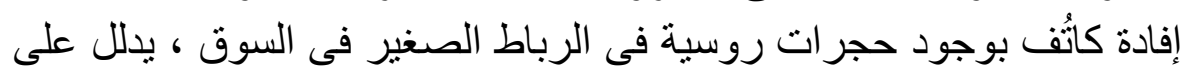

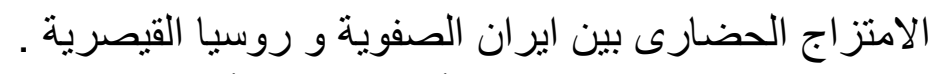
lV الصفقات التجارية . - الصارت

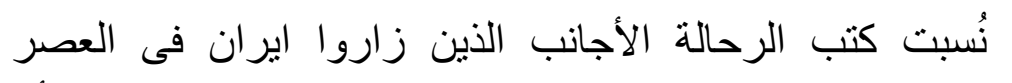

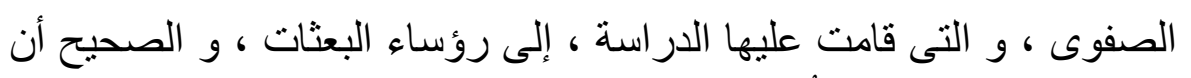

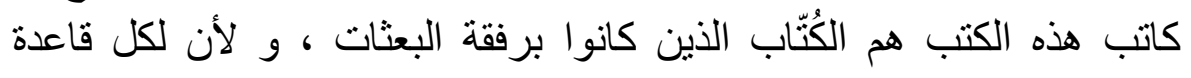

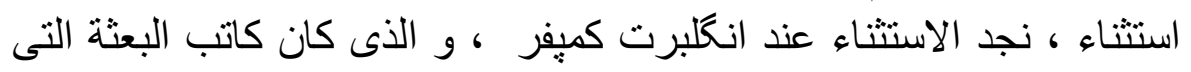

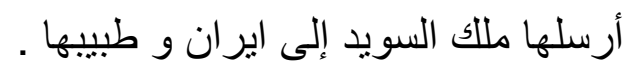




\section{المصادر و المراجع باللغة العربية : - المبية}

- ابن الأثير : عز الدين أبى الحسن على بن عبد الكريم الجزرى ، الكامل فى

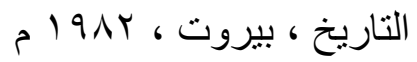

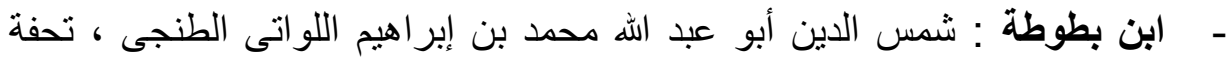

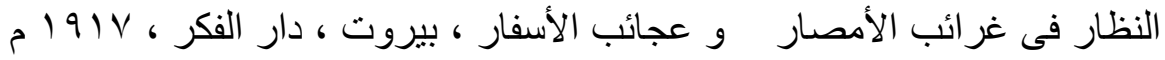

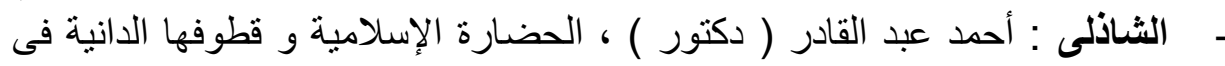

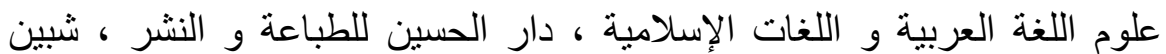

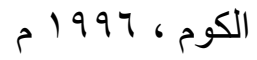

ـ - الصياد : فؤاد عبد المعطى ( دكتور ) ، المغول فى التاريخ ، بيروت ، دار

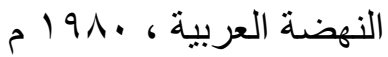

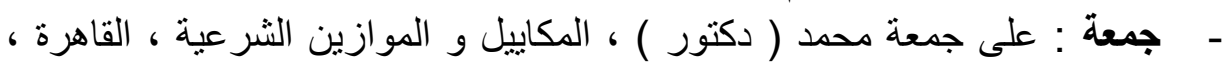

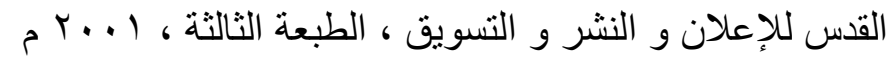

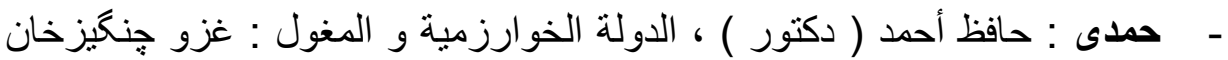
للعالم الإسلامى و آثاره السياسية و الدينية و الاقتصادية و الثقافية ، القاهرة ، دار الثران

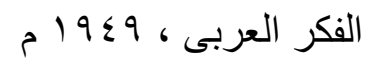

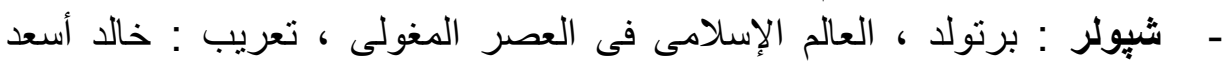

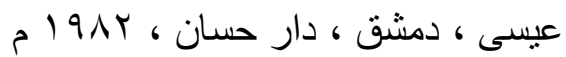

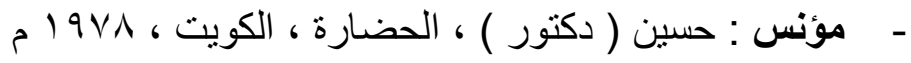

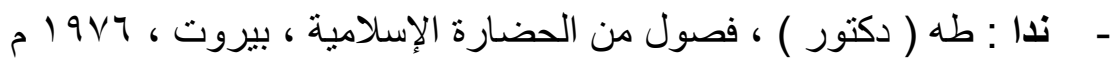


- ابن جبير : محمد بن احمد ، سفرنامهاء ابن جبير ، ترجماء بِرويز اتابكى ، مشهر

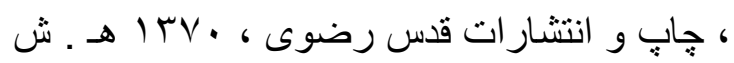

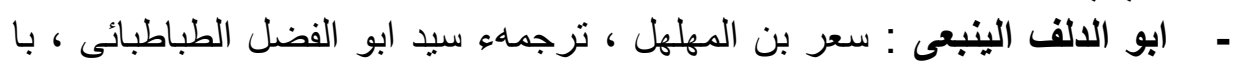

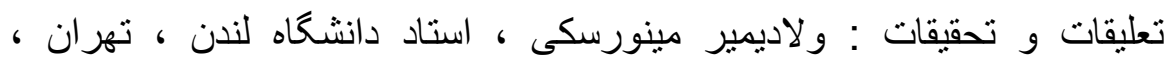

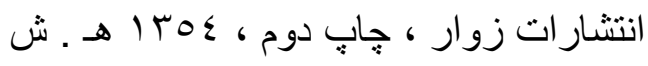
- اشراقى : فيروز ، اصفهان از ديدن سياحان خارجى ، اصفهان ، آترويات ،

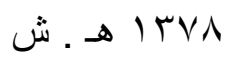

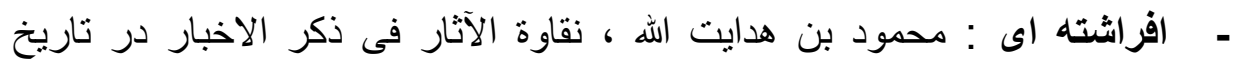

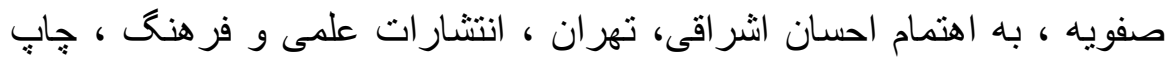

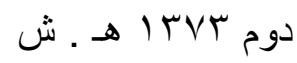
- برن : رهر ، نظام ايالات در دورهء صفويه ، ترجمهء كيكاووس جهاندارى ،

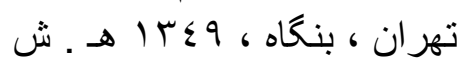

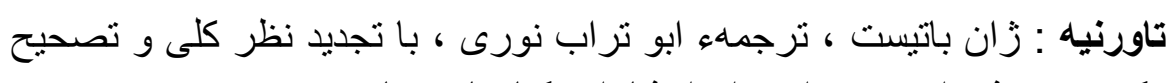

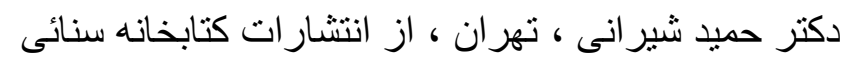

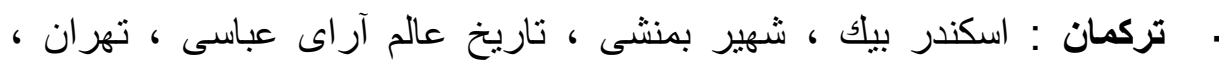

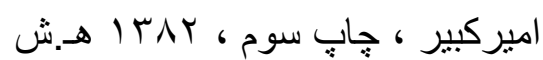

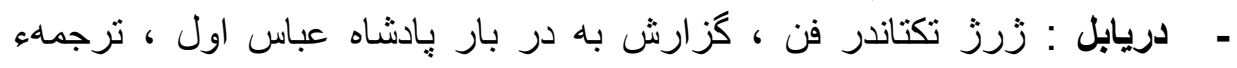

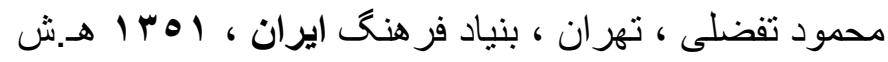

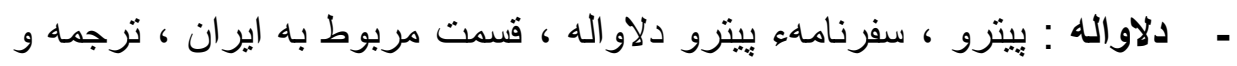

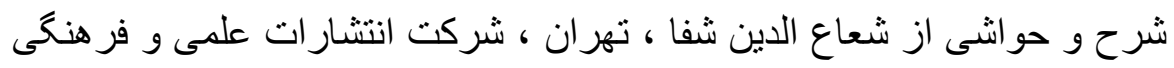

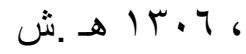

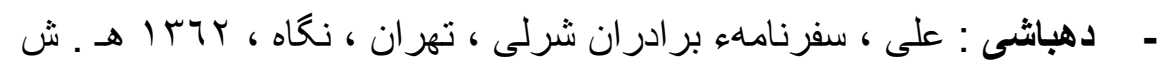

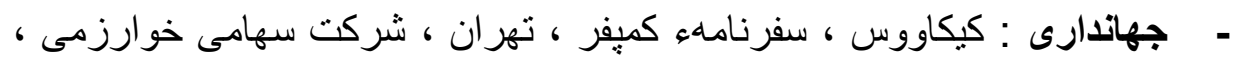

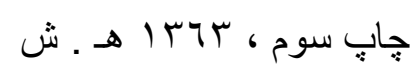

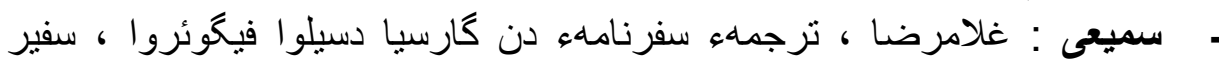

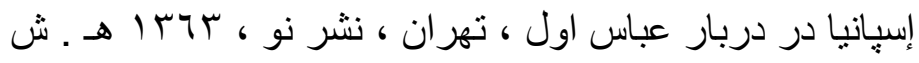

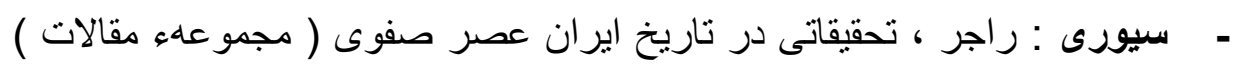

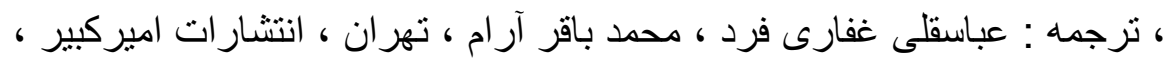

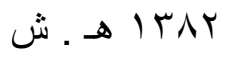


- شاردن : زان ، سياحتنامه شاردن ، ترجمه : محمد عباسى ، با حواشىى و و

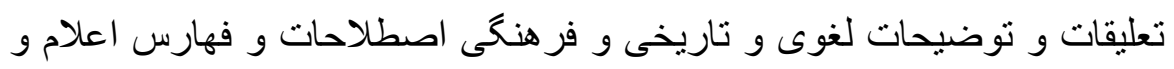

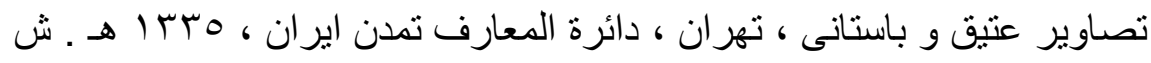

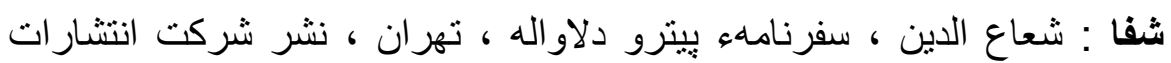

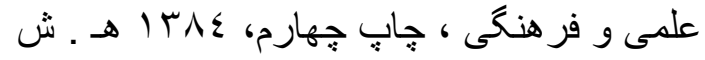

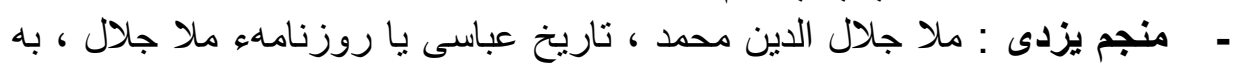

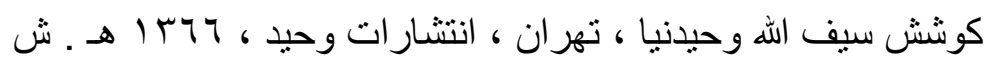

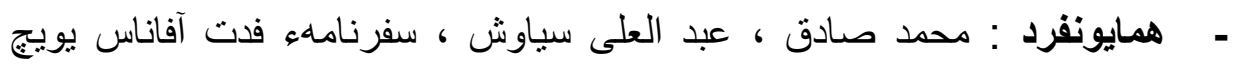

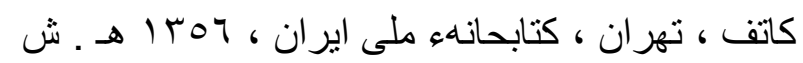

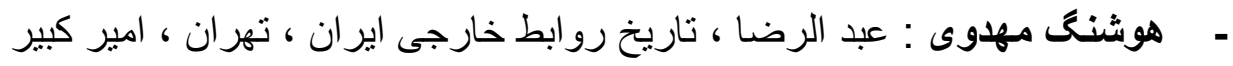

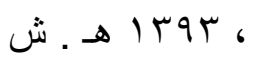

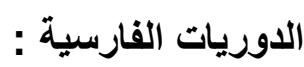

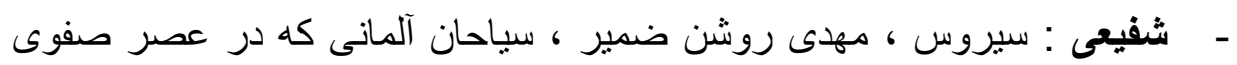

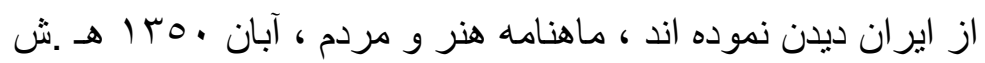

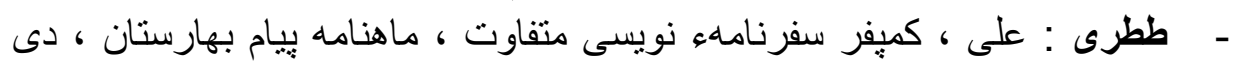

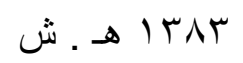

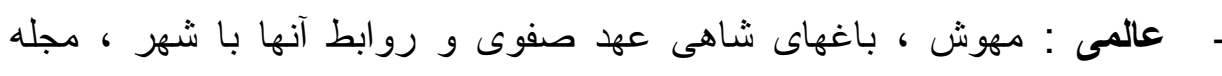

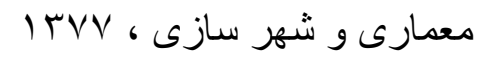

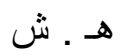
مبين : ابو الحسن ، ايران عصر صفوى از نحكاه انكلبرت كميفر ، ماهنامه كتاب

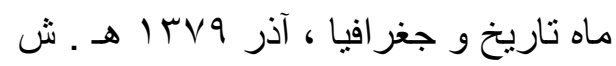

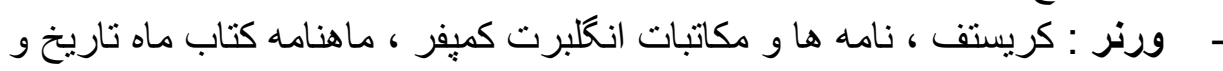

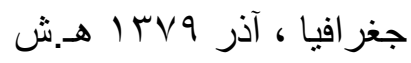

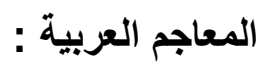

- الرازى : الثيخ محمد بن أبى بكر بن عبد القادر ، مختار الصحاح ، عنى بترتيبه

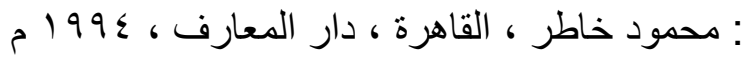

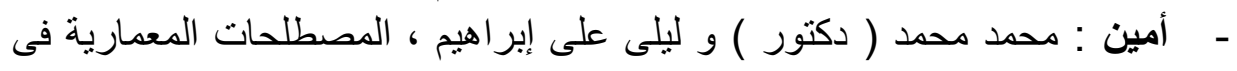

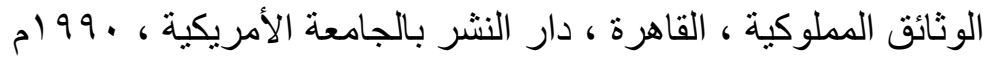


- مصطفى : إبراهيم و أخرون ، المعجم الوسيط ، القاهرة ، دار المعارف ، . 197 م

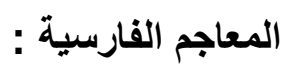

- فر هنى جغر افيائى ايران ، از انتشارات دايره جغر افيائى ستاد ارنش ، تهران

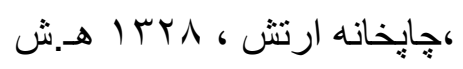

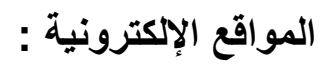

$$
\text { - }
$$

www.radiofarhng.ir 